UNIVERSIDADE DE SÃO PAULO

FACULDADE DE FILOSOFIA, LETRAS E CIÊNCIAS HUMANAS DEPARTAMENTO DE LETRAS MODERNAS

PROGRAMA DE PÓS-GRADUAÇÃO EM LÍNGUA ESPANHOLA E LITERATURAS ESPANHOLA E HISPANO-AMERICANA

\title{
PENELOPÉIAS SILENTES
}

Romilda Mochiuti

\begin{abstract}
Tese apresentada ao Programa de PósGraduação em Língua Espanhola e Literaturas Espanhola e Hispanoamericana, do Departamento de Letras Modernas da Faculdade de Filosofia, Letras e Ciências Humanas da Universidade de São Paulo, para obtenção do título de Doutora em Letras.
\end{abstract}

Orientador: Prof. Dr. Mario Miguel González

São Paulo

2006 


\section{UNIVERSIDADE DE SÃO PAULO}

FACULDADE DE FILOSOFIA, LETRAS E CIÊNCIAS HUMANAS DEPARTAMENTO DE LETRAS MODERNAS PROGRAMA DE LÍNGUA ESPANHOLA E LITERATURAS ESPANHOLA E HISPANO-AMERICANA

\section{PENELOPÉIAS SILENTES}

Romilda Mochiuti

São Paulo

2006 


\section{Agradecimentos}

À CAPES pela bolsa-sandwich de quatro meses na Espanha, sem a qual boa parte da pesquisa aqui realizada seria inviabilizada.

Ao professor Dr. Mario Miguel González, pela confiança no projeto inicial, pelo apoio irrestrito às mudanças e pela leitura pontual desta tese.

À professora Eva Guerrero Guerrero, da Universidade de Salamanca, pela acolhida calorosa, ajuda bibliográfica e orientação em terras cervantinas.

Aos meus familiares pela tentativa de entender os silêncios, as constantes ausências, as crises de ansiedade e nervosismo e a falta de atenção e dedicação.

A Mónica e ao Jaime pela amizade irrestrita, pela carinhosa acolhida em sua casa e o apoio incondicional em terras madrilenas.

Aos funcionários da Biblioteca Nacional em Madri e da biblioteca da FFLCH, pela valiosa ajuda na busca por livros e artigos que não faziam parte de seu acervo.

À banca de qualificação, em especial à crítica e leitura arguta do professor Augusto Massi.

A Edite, secretária do DLM, pelo profissionalismo e disposição que se traduziram em amizade.

Aos amigos, pelas críticas, revisões, sugestões e propostas de leituras. 
Dedicatória

Ao meu pai, que sempre me incentivou a estudar, À minha mãe, que sempre me estimulou a brincar, Aos meus irmãos, que brincaram e leram comigo., 


\section{Resumo}

O propósito deste trabalho é analisar os dois romances, Uma aprendizagem ou o livro dos prazeres, de Clarice Lispector, e El silencio de las sirenas, de Adelaida García Morales, respeitados seus respectivos referenciais literários, como releituras subversivas da tradição literária narrativa, operação esta que denominamos "penelopéias metaromancescas". Com este propósito, percorremos a tradição mítico-poética, a partir do modus operandi de cada romance, tendo em vista que cada um procura re-ler e

subverter os mitos de Ulisses, Penélope e das Sereias ao resgatar a voz discursiva feminina usurpada a partir da epopéia homérica, e revisamos alguns estudos que têm o romance como um gênero que nasce da epopéia.

Palavras-chave: meta-ficção, mito, romance, literatura espanhola e brasileira. 


\section{Abstract}

The purpose of this paper is to analyze the romances An apprenticeship or The book of pleasures by Clarice Lispector and The silence of the sirens, by Adelaida García, respecting their literary referential as subversives rereadings of the narrative literary tradition, an operation that we call "penelopees meta-ramancescs". With this aim we go through the poetic mythic tradition, from the modus operandi of each novel, having in mind that each one searches rereading and subverting the myths of Ulysses, Penelope and the Sirens when rescuing the female discursive voice seized from the Homeric epopee, and review some studies that have the romance as a genre that comes from the epopee.

Key words: meta-fiction, myth, romance, Spanish and Brazilian literature 


\section{Sumário}

Agradecimentos

3

Dedicatória

4

Resumo

Abstract

5

5

INTRODUÇÃO

9

Cap. I - Um gênero, várias teorias .............................................................. 14

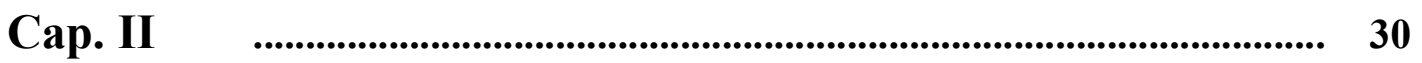

2.1- A alteridade: do mythos ao logos, uma interpretação narrativa .................... 30

2.2 - O fio puxado da renda: a obra clariciana e a crítica $\quad$................................. 36

2.3 - Um romance que é "o meio do caminho" $\quad$............................................. 46

2.4 - De Sereia a Penélope. Do canto à trama $\quad$............................................ 57

2.5 - A assombração do silêncio: "o núcleo último da pessoa" $\quad$.................... 67

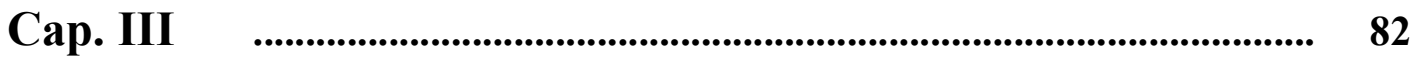

3.1 - A oltridade: do mythos à mimesis meta-ficcional $\quad$.................................. 82

3.2 - Uma literatura feminina? A obra de García Morales e a crítica ................. 93

3.3 - Uma narrativa que se faz narrativas $\quad$..................................................... 103

3.4 - De Penélope a Sereia: do canto ao silêncio $\quad$............................................... 112

3.5 - A sinfonia do silêncio

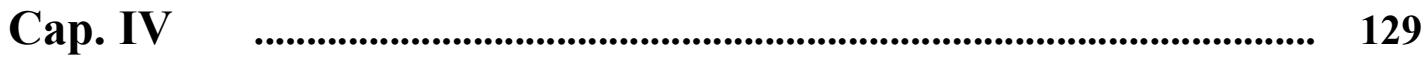

4.1 - Uma estrutura, múltiplas viagens $\quad$............................................................... 129

4.2 - Um mito, diversas releituras $\quad$............................................................. 137

4.3 - Os silêncios e as vozes da leitura $\quad$......................................................... 151

CONCLUSÃO

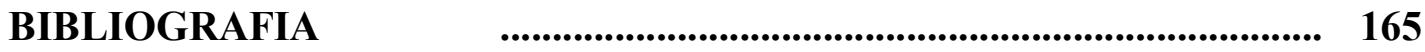

\footnotetext{
${ }^{1}$ Clarice Lispector, apud BORELLI: 1981: 14
} 


\section{ARTE POÉTICA}

"El escribir, como la vida misma, es un viaje de descubrimiento. La aventura es de carácter metafísico: es una manera de aproximación indirecta a la vida misma, de adquisición de una visión total del universo, no parcial."

HENRY MILLER

Mirar el río hecho de tiempo y agua y recordar que el tiempo es otro río, saber que nos perdemos como el río y que los rostros pasan como el agua.

Sentir que la vigilia es otro sueño que sueña no soñar y que la muerte que teme nuestra carne es esa muerte de cada noche, que se llama sueño.

Ver en el día o en el año un símbolo de los días del hombre y de sus años, convertir el ultraje de los años en una música, un rumor y un símbolo.

Ver en la muerte el sueño, en el ocaso un triste oro, tal es la poesía que es inmortal y pobre. La poesía vuelve como la aurora y el ocaso.

A veces en las tardes una cara nos mira desde el fondo de un espejo; el arte debe ser como ese espejo que nos revela nuestra propia cara.

Cuentan que Ulises, harto de prodigios, lloró de amor al divisar su Itaca verde y humilde. El arte es esa Itaca de verde eternidad, no de prodigios.

También es como el río interminable que pasa y queda y es cristal de un mismo Heráclito inconstante, que es el mismo y es otro, como el río interminable. 


\section{INTRODUÇÃO}

Al igual que al término de un viaje vuelve uno sobre el camino recorrido, sólo cuando se ha concluido un libro podemos reflexionar, a guisa de introducción, sobre el trabajo terminado e intentar definir lo que hemos hecho. Mientras las pesquisas siguen su curso nos empujan de un lado a otro, sin que podamos discernir con precisión por qué vía nos llevan ni a dónde nos conducen.

Jean Pierre Vernant

Ao tomarmos a Odisséia como um tema sem perder de vista as suas origens e suas características mítico-poéticas, encontramos vários autores que nos revelam de forma arrebatadora e critativa a sua também fascinação por esta obra homérica. Virgilio, Dante, Camões, Kafka, Borges são alguns dos grandes nomes que retomam o texto clássico e, com suas re-leituras muitas vezes subversivas, contribuem para gerar e avultar um sinuoso e instigante jogo laberíntico polifônico que se perpetua, ao longo da tradição literária, em espelhos que refletem imagens em um mise en abyme sem fim.

Este diálogo entre as várias obras e formas literárias - a polifonia ou, ainda, dialogia em termos bakhtinianos - reafirma a estrutura do romance como gênero que, já em suas origens cervantinas, incide sobre o fascínio da viagem, seja como tema ou, ainda, como princípio organizador da estrutura narrativa, aspecto este que também remonta à epopéia clássica: tal qual Ulisses que ouve suas peripécias na corte dos feácios e que, em um ato subversivo, toma voz para cantar per se as próprias aventuras, a personagem dom Quixote, na segunda parte do romance, também age subvertendo as estruturas narrativas. 
Com efeito, o que nos motiva são atos subversivos que permeiam outra polifonia, a elidida. Se Ulisses empossa a voz do canto, não o faz, entretanto, sem silenciar uma outra, a do aedo. Mas, a epopéia homérica tem lá suas outras sutilezas.

As Sereias, que entoavam o seu canto sedutor, são seres que o relato homérico, além de silenciar ante o "heróico" sacrifício ulissiano, abandona a um infinito mar de errâncias possíveis. Qual teria sido o fim daquelas beldades mortíferas, ou ainda, qual a história daquelas contra-musas? A tradição se encarrega até hoje de tentar divisá-la.

E o que dizer da multifacetária Penélope? Símbolo controverso de fidelidade e traição, ela é aquela que com o fio des-tece uma mortalha, esta engenhosa metáfora da trama, da tessitura, do con-fabular. Mas, a "eterna esposa" fiel, por um outro lado e assimétricamente, revela-se como uma mãe reticente.

São estas vozes silenciadas que nos propomos escutar, através de um estudo e de uma análise contrastiva dos romances Uma aprendizagem ou O livro dos prazeres, de Clarice Lispector, e El silencio de las sirenas, de Adelaida García Morales, como obras que tencionam dar voz a essas "silentes" personagens míticas homéricas.

Penelopéias, portanto, são périplos que resgatam as vozes femininas silenciadas. Esta instauração polifônica que pensamos ser a base estrutural dos dois romances, tenhamos claro antes de mais nada, já tem em suas origens a constituição de uma dialogia que, por si só, representa uma estrutura literária tão complexa quanto o universo no qual elas se inserem. Delineemos, brevemente aqui, quais as diretrizes desta nossa premissa de leitura.

Para não perdermos de vista o nosso propósito, concentramo-nos nas hipóteses que inicialmente nos levaram a relacionar a trama dessas duas obras: ambas se projetam a partir da tradição literária ocidental, através da retomada de alguns "fios soltos" da 
trama odisséica o que, se por um lado as irmana, por outro, permitem-nos traçar os seus respectivos perfís miméticos característicos.

Com relação a esses perfis miméticos, concentramo-nos na análise das personagens principais de cada romance, partindo do princípio de que ambas instauram polifonicamente as vozes silenciadas na Odisséia - Sereias e Penélope -, o que caracterizaria uma subversão do relato mítico em sua forma e conteúdo.

Sob este aspecto, alguns elementos da trama de ambas narrativas, associados ao caráter polifônico que suscitam, permitiram-nos organizar também um diálogo entre a teoria e a crítica relacionadas tanto ao tema como aos dois romances, o que nos serviu para tecer algumas ponderações com relação à hermenêutica instaurada, estabelecedora do canon.

Não é por mera casualidade que a estrutura narrativa - e a romancesca, conseqüentemente - constituiu-se em um dos principais focos de nossa análise. Não obstante o vultuoso e divergente acervo crítico que há acerca do romance, cabe elucidar, a linha teórica que aqui aportamos seguiu, por sua vez, os passos que os dois romances nos indicaram: a de que este gênero tem suas origens na epopéia.

Neste sentido, notamos que as duas estruturas narrativas apresentam de forma explícita uma dialética em comum: uma leitura paródica da forma como voz e presença feminina se apresentam na estrutura mítico-poética. Tal operação na medida em que ocorre por meio da figuração do narrador, concomitantemente, recupera a noção de que o artifício do urdir, do tramar está intimamente relacionado ao universo e à astúcia feminina. Esta astúcia - ou a metis em grego - leva-nos necessariamente às suas raízes míticas.

De acordo com Vernant e Detienne:

En el plano del vocabulario metis designa, como nombre común, una forma particular de inteligencia, una prudencia astuta; como 
nombre propio, una divinidad femenina, hija de Océano. La diosa Metis, personaje que podríamos creer bastante desdibujado, parece estar confiada a los papeles de comparsa. Primera esposa de Zeus, apenas se encuentra embarazada de Atenea fue devorada por su marido. Relegándole a las profundidades de su vientre, el rey de los dioses puso fin brutalmente a su carrera mitológica. Sin embargo, en las teogonías atribuidas a Orfeo, Metis figura en primer plano y aparece en el origen del mundo como una gran divinidad primordial. (1988: 10)

É das profundezas discursivas - figuração do poder hegemônico da voz masculina na representação literária - que vemos, nestes dois romances, que a voz feminina elidida se alça e busca reverter os simulacros de sua representação.

Com efeito, a trajetória que delineamos teve a intenção de contemplar forma e conteúdo das obras no que se refere aos seus paradigmas literários e à tradição na qual as inserimos. Para verificar o modus operandi de cada romance e entendermos melhor de que maneira tema, estrutura e prática mimética subversivas se aproximam e se distanciam, o presente estudo se dividiu em quatro capítulos.

O primeiro se detém em delinear e apontar a teoria e a crítica com as quais estamos trabalhando e que serão aprofundadas na medida do necessário na primeira parte dos dois capítulos seguintes. O segundo e o terceiro capítulos - divididos em cinco subcapítulos, tematicamente simétricos - tratam de apresentar e analisar, respectiva e separadamente, o romance de Lispector e o de García Morales. Já o quarto, trata de realizar uma análise contrastiva dos elementos comuns e díspares presentes nos dois romances. Na Conclusão, revisamos o saldo de nosso périplo: advertimos alguns contratempos e "cantamos" algumas conquistas.

Cabe aqui esclarecer que o presente estudo, devido ao seu propósito, exime-se da intenção de esgotar a obra de cada autora em seu aspecto sincrônico ou diacrônico. 
Se sabe que Proust no ha descrito en su obra la vida tal y como ha sido, sino una vida tal y como la recuerda el que la ha vivido. $Y$, sin embargo, está esto dicho con poca agudeza, muy, pero muy bastamente. Por que para el autor reminiscente el papel capital no lo desempeña lo que él haya vivido, sino el tejido de su recuerdo, la labor de Penélope rememorando. ¿O no debiéramos hablar más bien de una obra de Penélope, que es la del olvido? ¿No está más cerca el remoderar involuntario, la mémoire involuntaire de Proust, del olvido que de lo que generalmente se llama recuerdo? ¿Y no es esta obra de rememoración espontánea, en la que el recuerdo es el pliegue y el olvido la urdidumbre, más bien la pieza opuesta a la obra de Penélope y no su imagen y semejanza? Porque aqui es el día el que deshace lo que obró la noche. Cada mañana, despiertos, la mayoría de las veces débiles, flojos, tenemos en las manos no más que un par de franjas del tapiz de la existencia vivida, tal y como en nosotros las ha tejido el olvido.

Walter Benjamín, "Una imagen de Proust"

$O$ romance é a forma da virilidade madura, em contraposição à puerilidade normativa da epopéia; a forma do drama, à margem da vida, situa-se além das idades humanas, mesmo se compreendidas como categorias apriorísticas, como estágios normativos. $O$ romance é a forma da virilidade madura: isso significa que a completude de seu mundo, sob a perspectiva objetiva, é uma imperfeição, e em termos da experiência subjetiva uma resignação.

G. Lukács, A teoria do romance 


\section{Capítulo I}

\section{Um gênero, várias teorias}

A análise dos dois romances contemporâneos, objeto de estudo desta tese como releituras atuais e, sobretudo, como uma revisão da voz discursiva presente no mito de Ulisses e Penélope e das Sereias na Odisséia, requer, antes de qualquer incursão analítica, uma leitura reflexiva de revisão de alguns conceitos que reiterada e sistematicamente utilizaremos ao longo de seu desenvolvimento.

Por esta razão, antes de procedermos à análise individual e contrastiva das duas obras, repassaremos aqui alguns conceitos e críticas que nos servem de base teórica. Advertimos de antemão que não temos a intenção de teorizar, senão apenas revisar alguns dos conceitos com os quais estamos trabalhando. Passemos, então, a recapitulação de algumas postulações sobre o gênero romancesco, uma vez que as obras das quais nos ocuparemos pertencem, dentro de suas idiossincrasias, a este gênero.

Para alguns estudiosos, o romance tem a sua origem na epopéia grega, da qual ainda guarda algumas características: "O romance é a epopéia de uma era para a qual a totalidade extensiva da vida não é mais dada de modo evidente, para a qual a imanência do sentido à vida tornou-se problemática, mas que ainda tem por intenção a totalidade". Com estas palavras Lukács sustenta, em seu clássico Teoria do Romance (2003: 55), que a "epopéia dá forma a uma totalidade de vida fechada a partir de si mesma" e que, em contrapartida, "o romance procura descobrir e construir, pela forma, a totalidade oculta da vida" (2003: 60). À procura destas descoberta e edificação da "totalidade 
oculta" surge o herói ${ }^{2}$ romancesco como a personificação psicologizada e individual do espírito da busca.

O estudioso húngaro se detém em vários aspectos que distanciam e aproximam a epopéia e o romance. Com relação à forma - verso ou prosa -, classifica-a como um critério superficial para estabelecer características decisivas que permitam defini-los como gêneros diferentes. Entretanto, dialeticamente pondera que o verso e a prosódia aproximam cada obra à essência de seu gênero. O estudioso pontua ainda a importância da oralidade, aspecto este no qual nos convém determos um pouco, uma vez que, para alguns estudiosos, este elemento é essencial para o entendimento da constituição da epopéia como gênero literário.

Conforme Adorno e Horkheimer, a Odisséia apresenta a passagem do mythos ao logos. Este movimento se acentua como ruptura da convivência submissa do homem com os deuses, na medida em que o percebemos, também, como a passagem da tradição do uso da voz, ou seja, da prática de uma memória centrada na oralidade para a prática da escrita; em outras palavras, para uma estrutura que requer certa habilidade lógica para compreensão ${ }^{3}$. A transmissão da memória, portanto, passou a ser representada pela escrita, relegando à oralidade um segundo plano que, ao longo do tempo, perde o seu estatuto de representatividade do fatum:

O destino mítico, fatum, e a palavra falada eram uma coisa só. A esfera das representações a que pertencem as sentenças do destino

\footnotetext{
${ }^{2}$ Lukács caracteriza o herói moderno, ou seja, o herói romancesco correlacionando as suas ações aos valores também modernos. Para o estudioso os limites que separam o crime do heroísmo positivo e a loucura da sabedoria capaz de dominar a vida são fronteiras movediças. É interessante notar que Lukács assinala que o herói romancesco é um indivíduo épico que nasce da alteridade do mundo exterior. Lucien Goldman - de cujo estudo se vale Alfredo Bosi para desenvolver a sua interpretação histórica da narrativa brasileira, conforme veremos no capítulo II - desenvolve sua teoria genético-estrutural do romance moderno pressupondo a dialética tensão entre o narrador e a sociedade, a partir das idéias de Lukács. Bakhtin, por sua vez, também classificará o romance como o gênero de tensões, como veremos mais adiante. Adorno e Horkheimer (1985: 56) também, em certa medida, contemplam este ponto de vista ao afirmarem que "Como os heróis de todos os romances posteriores, Ulisses por assim dizer se perde a fim de se ganhar. Para alienar-se da natureza ele se abandona à natureza, com a qual se mede em toda aventura, e, ironicamente, essa natureza inexorável que ele comanda triunfa quando ele volta - inexorável - para casa, como juiz e vingador do legado dos poderes de que escapou."

${ }^{3}$ Daí a utilização pelos estudiosos do termo "esclarecimento".
} 
executadas invariavelmente pelas figuras míticas ainda não conhece a distinção entre palavra e objeto. A palavra deve ter um poderio imediato sobre a coisa, a expressão e a intenção confluem. A astúcia, contudo, consiste em explorar a distinção, agarrando-se à palavra, para modificar a coisa. Surge assim a consciência da intenção: premiado pela necessidade, Ulisses se apercebe do dualismo, ao descobrir que a palavra idêntica pode. Como o nome Oudeis pode ser atribuído tanto ao herói quanto a ninguém. (1985: 65)

Os estudiosos (1985: 31) afirmam, ainda, que "com a nítida separação da ciência e da poesia, a divisão de trabalho já efetuada com sua ajuda estende-se à linguagem. É enquanto signo que a palavra chega à ciência”.

É, com efeito, a partir da poesia épica homérica e da tradição hermenêutica que a tem como um dos pilares da literatura ocidental que se institui uma mimesis que flagra o jogo do poder de re-presentação e omissão polifônico que ainda hoje vigora em outro gênero, o romance ${ }^{4}$.

Esta figuração de poder na épica, por um outro lado e não obstante a forma cadente do verso empregado que confere ao ritmo o significado do gênero, também instituiu o domínio da oralidade e da escrita como intrinsecamente masculinos, uma vez que tanto poeta, como aedo e heróis são essencialmente masculinos ${ }^{5}$.

Assim, tal qual a "democracia", cujo significado atual alcança uma abrangência que em suas origens não apresentava, o "sentido de totalidade" do mundo homérico tão somente se referia a uma visão intrinsecamente reservada ao seu universo cultural

\footnotetext{
${ }^{4}$ A respeito desta "marginalização" polifônica, os filósofos frankfurtianos (1985: 64-5) salientam com relação ao episódio das Sereias, no cap. XII, que "A epopéia cala-se acerca do que acontece às cantoras depois que o navio desapareceu. Mas, na tragédia, deveria ter sido sua última hora, como foi a da Esfinge quando Édipo resolveu o enigma, cumprindo sua ordem e assim precipitando sua queda. Pois o direito das figuras míticas, que é o direito do mais forte, vive tão-somente da impossibilidade de cumprir seu estatuto. Se este é satisfeito, então tudo acabou para os mitos até sua mais remota posteridade. Desde o feliz e malogrado encontro de Ulisses com as Sereias, todas as canções ficaram afetadas, e a música ocidental inteira labora no contra-senso que representa o canto na civilização, mas que, ao mesmo tempo, constitui de novo a força motora de toda arte musical.” E, acrescentamos, da polifonia romancesca.

${ }^{5}$ Cabe aqui pontuarmos, ainda que brevemente, que não obstante a epopéia ser um gênero constituído pela elaboração escrita da linguagem oral, entrevemos através desta já peculiar forma de dominação masculina uma diáfana imagem do universo feminino.
} 
fechado. Esta representação se estabelece literariamente ao longo dos tempos, como nos esclarece Lukács, na transposição de um mundo homogêneo, cujo sentido positivo da totalidade denota uma união entre a interioridade e a exterioridade, a existência e a essência, o ser e o destino, a aventura e o acabamento; em síntese, trata-se da representação de um destino coletivo, através de um ser que a representa.

Adorno e Horkheimer, revisando este conceito, acrescentam o fato de que a mimesis apresentada na Odisséia já denuncia a fragmentação da "totalidade do mundo" que representa; em outras palavras, os estudiosos colocam em evidência em seu estudo o início da fragmentação do mundo clássico no poema homérico ${ }^{6}$.

É, portanto, através da representação de um universo que já dá sinais de sua desintegração que, ironicamente, temos notícia de sua homogeneidade. A oposição entre cultura e civilização, respectivamente, mundo homogêneo / epopéia e mundo heterogêneo / romance apresentada por Lukács, adquire também um outro significado sob a luz dos estudos dos filósofos frankfurtianos: a representação homérica já anuncia a fragmentação do mundo através da inclusão da metis ulissiana ${ }^{7}$.

Pontuam os estudiosos frankfurtianos que, se na epopéia há a coincidência entre a existência e a essência, o ser e o destino, a aventura e o acabamento, esta dialética somente se viabiliza pela astúcia ulissiana que cinde com a qualidade de mero fantoche na mão de "temperamentais" deuses para operar como coadjuvante de uma vontade coletiva diversa.

\footnotetext{
${ }^{6}$ Com relação a este aspecto, os filósofos frankfurtianos (1985:55) apontam que o estudioso Rudolf Borchardt ao "denunciar sem maiores qualificações a epopéia como romance, deixa escapar que a epopéia e o mito têm de fato em comum: dominação e exploração". Neste sentido, os estudiosos (1985: 79) ponderam que a "transposição dos mitos para o romance, tal como ocorre na narrativa das aventuras, é menos uma falsificação dos mitos do que um meio de arrastar o mito para dentro do tempo descobrindo o abismo que o separa da pátria e da reconciliação", concluindo (1985: 80) que "É só como romance que a epopéia se transforma em conto de fadas".

${ }^{7}$ É esta a astúcia que "tem sua origem no culto. O próprio Ulisses atua ao mesmo tempo como vítima e sacerdote" salientam Adorno e Horkheimer (1985: 53). Daí a afirmação dos estudiosos de que a "ratio, que recalca a mimese, não é simplesmente seu contrário. Ela própria é mimese: a mimese do que está morto" (1985: 62).
} 
O romance, como gênero originário da epopéia, herdará não somente essa ruptura - sinônimo de crise -, como a levará a experimentalismos extremos ${ }^{8}$. O choque, que apenas entrevemos no uso que Ulisses faz de sua astúcia, transforma-se no sintoma que regerá o mundo e seu máximo representante / herdeiro literário, o romance ${ }^{9}$ : o indivíduo problemático em choque com o mundo, ora transformado em herói problemático, abandona o sentimento do coletivo e parte em uma busca individual do sentido da vida.

Ainda que, em sua representação, haja um questionamento ineludível - mimesis de um mundo em crise -, esta heterogeneidade romancesca, segundo Lukács, prima pela representação de sua totalidade intrínseca.

O estudioso húngaro nos esclarece ainda que, as relações que dão coerência aos elementos que constituem o romance obedecem a um último princípio unificante que não pode ser outro senão "a ética da subjetividade criadora que se torna nítida no conteúdo" (LUCKÁCS: 2003: 85). Por esta razão, a ironia exerce um papel fulcral e fundamental, uma vez que ela representa a liberdade de criação e se torna um "meio moderno de estruturação" da narrativa (apud DAMIÃO: 2005: 315). Para Lukács, a ironia desdobra-se em duas direções: ela não apenas apreende a desesperança da luta entre indivíduo e mundo, como ainda revela a também desesperança advinda do profundo abandono da "idealidade irreal da alma em prol de um controle da realidade" (2003: 87).

Assim, na ruptura intrínseca presente na relação dialética entre cultura e civilização, mundo homogêneo e heterogêneo, o romance como gênero originário da

\footnotetext{
${ }^{8}$ Daí a afirmação de Lukács de que "nos tempos felizes" anteriores à helenidade não existia a filosofia, uma vez que esta surge somente a partir da separação entre interioridade e exterioridade. A "filosofia corresponderia, portanto, ao próprio sintoma da dilaceração entre indivíduo e mundo e, por conseqüência, da 'quebra' do sentimento de totalidade" (apud DAMIÃO: 2006: 314).

${ }^{9}$ Por esta razão, quando o mundo entra em crise esta se traduz também na forma romancesca, daí Benjamin apressadamente afirmar que o romance havia entrado em franco declínio.
} 
epopéia, segundo o estudioso, alcança através da ironia num mundo sem deus uma autoliberação subjetiva na qual

a psicologia do herói romancesco é a demoníaca; a objetividade do romance, a percepção virilmente madura de que o sentido jamais é capaz de penetrar inteiramente a realidade, mas de que, sem ele, esta sucumbiria ao nada da inessencialidade - tudo isso redunda numa única e mesma coisa, que define os limites produtivos, traçados a partir de dentro, das possibilidades de configuração do romance e ao mesmo tempo remete inequivocamente ao momento histórico-filosófico em que os grandes romances são possíveis, em que afloram em símbolo do essencial que há para dizer. (2003: 79-80)

Não nos esqueçamos que Benjamin, apesar de anunciar o fim do gênero romancesco já bem avançada a primeira metade do século $\mathrm{XX}$, comenta:

La novela, cuyos inicios remontan a la antigüedad, requirió cientos de años, hasta toparse, en la incipiente burguesía, con los elementos que le sirvieron para florecer. Apenas sobrevenidos estos elementos, la narración comenzó, lentamente, a retraerse a lo arcaico; se apropió, en más de un sentido, del nuevo contenido, pero sin llegar a estar realmente determinado por éste. Por otra parte, nos percatamos que, con el consolidado dominio de la burguesía, que cuenta con la prensa como uno de los principales instrumentos del capitalismo avanzado, hace su aparición una forma de comunicación que, por antiguo que sea, jamás incidió de forma determinante sobre la forma épica. Por ahora sí lo hace. (1991: 116)

São vários os elementos, sem lugar a dúvidas, que contribuirão para que o romance - como bem avaliou Lukács com relação ao romance realista - seja considerado o gênero representativo da burguesia, classe social esta que surge na raiz do mundo $\operatorname{moderno}^{10}$.

Não obstante a convergência ideológica que Benjamin estabelece a partir da obra de Lukács ao destacar que este gênero tem sua origem na epopéia e no surgimento da burguesia, as divergências, por um outro lado, acentuam a particularidade do

\footnotetext{
${ }^{10}$ Com relação a este conceito, seguimos os parâmetros teóricos de Carlos Fuentes, conforme veremos mais adiante no item 2.1 (capítulo II).
} 
pensamento de cada um ao passo que nos levam a outros questionamentos relativos à natureza da riqueza que a épica relegou ao gênero romancesco, conforme Luís Inácio Costa nos esclarece:

Distante de uma preocupação estrita com a teoria dos gêneros, o conceito benjaminiano do épico tal como formulado em $O$ narrador pretende, antes, dar conta da narração como uma modalidade artesanal de linguagem vinculada profundamente à tradição / transmissão, à memória comum, à experiência comunicável. Tomando como referência as formas da grande épica descrita por Lukács em sua Teoria do romance, Benjamin reconhece no grande manancial da épica a origem comum das várias narrativas - tanto da crônica e da historiografia quanto da epopéia e do romance - assim como das diferentes modalidades de memória narrativa a elas correspondentes. (2005: 56)

Benjamin, por um outro lado e ressaltando o legado da tradição, entende a partir de uma interpretação da obra de Lukács que o romance certamente incorpora o tempo na série de seus princípios constitutivos - atributo este característico da epopéia -, mas que, entretanto, o faz de forma insurgente.

Claro está que, o conceito lukacsiano de que o princípio unificante que não pode ser outro senão a ética da subjetividade criadora mediada pela ética do conteúdo como apontávamos anteriormente - na compreensão / configuração do tempo na estrutura romancesca é o reflexo do choque do indivíduo com o mundo fragmentado, cindindo existência / essência, ser / destino, aventura / acabamento.

Assim, dentro dos critérios estabelecidos por Benjamin para a experiência, a partir da leitura lukacsiana do romance, podemos vislumbrar a condição do romance como a de um gênero cuja gênese remonta à epopéia no sentido de apropriar-se da palavra para a expressão da experiência - mimesis - tal como Ulisses-aedo o faz na corte dos feáceos.

Esta mudança de voz discursiva, ou antes, esta apropriação do discurso que lhe competiria a outro que não a personagem cantada, esta astúcia ulissiana que tão 
sagazmente será recuperada e aprofundada pela experiência narrativa kafkiana, é a que pensamos ser uma das raízes do conceito da dialogia romanesca bakhtiniana.

Seguindo esta proposição, podemos nos aproximar do conceito que Bakhtin desenvolve sobre o romance. Para este estudioso russo (BAKHTIN: 2004: 159), o gênero romancesco tem três raízes principais: a epopéia, a retórica e o carnaval. Em palavras de Irene Machado:

Romance é para Bakhtin um gênero literário em prosa, constituído pela multiplicidade discursiva das línguas e das linguagens. Daí uma das noções mais ricas formuladas por Bakhtin seja a de romance como representação do homem e de sua linguagem ou a shaz iazihá, a imagem da linguagem. (1995: 50)

Entendemos no trabalho desenvolvido por Bakhtin sobre a poética de Dostoiévski e nas ponderações que Machado nos apresenta sobre seus estudos - em outras palavras, com relação à teoria bakhtiniana do romance e a partir das reflexões que vimos tecendo com relação ao pensamento de Lukács, Adorno, Horkheimer e Benjamin - que, por um lado, podemos caracterizar o romance como um gênero que se constitui pela representação da imagem do homem e de sua linguagem, entendida esta linguagem como a experiência de um mundo fragmentado e a representação como a ruptura com este mundo, e que ambas - linguagem e a representação - carregam em si uma consciência tanto individual quanto coletiva. Por outro lado, também podemos entender experiência como a representação mimética individual do autor como leitor da tradição literária.

Ainda que para Bakhtin o romance é um gênero híbrido, esta afirmação não refuta, antes, reforça a idéia inerente ao pensamento dos filósofos aos quais nos referimos, uma vez que para esse teórico russo, conforme nos esclarece Irene Machado, a oralidade é a expressão complexa de diversos fenômenos estéticoculturais marcados pela noção de que poesia é voz e toda análise 
textual depende da existência discursiva da obra oral. Uma busca do movimento entre oralidade e escritura. (1995:21-2)

Em outras palavras, ao reforçar a importância do aspecto oral na busca do movimento entre oralidade e escritura, Bakhtin nos leva de volta à questão intrínseca à épica homérica ao mesmo tempo em que nos coloca diante do problema da experiêncial" do romance moderno ao estabelecê-lo, também, como "o gênero das tensões" (MACHADO: 1995: 20).

Mas, antes de caracterizar o romance como o gênero das tensões, o teórico russo:

Numa de suas formulações mais precisas sobre o processo paródico, observa que o romance é um gênero capaz de pôr em xeque não só as estruturas composicionais de outros gêneros, como também de submeter os elementos internos de sua própria organização a um contínuo processo de revisão crítica, que Bakhtin entende como manifestação do metacriticismo. (MACHADO: 1995: 63)

Este movimento de voltar a si mesmo com um olhar crítico - o que não deixa de ser um dos marcos da tensão do romance - aliado ao fato de ser um gênero de linguagens em confronto (mundo / indivíduo) contribuem para acentuar a sua característica forma inacabada $^{12}$. Bakhtin, por um outro lado, relaciona a esta estrutura composicional o dialogismo: recurso romancesco de representação e apropriação estilística tanto da voz das personagens como também de estilos, de épocas e de grupos sociais.

Tanto Bakhtin quanto Lukács entendem que a ironia é a figura retórica que potencializa a estrutura narrativa do romance. Entretanto, o lingüista russo a estuda

\footnotetext{
${ }^{11}$ Enquanto para Benjamin o conceito de experiência é fundamental, para Bakhtin este conceito, ou antes, a importância de seu sentido se traduz na enunciação uma vez que esta, para o lingüista russo, é a manifestação da linguagem vivenciada.

${ }^{12}$ Para Bakhtin, esta particularidade é uma das principais causas para que não se tenha desenvolvido uma poética ou um criticismo do romance comparável ao que existe a respeito do poema. (conf. MACHADO: 1995: 81)
} 
como um desdobramento dialógico. Cabe ressaltar que a apropriação estilística exercida pelo dialogismo e seus desdobramentos - neste caso, a ironia - é a base do conceito bakhtiniano de paródia.

Neste sentido, podemos entender a paródia não apenas como um recurso estilístico que intensifica as tensões romancescas, como a entende Lukács, mas também como um expediente que acentua sua característica de forma inacabada. Não obstante estes aspectos, a paródia - como podemos notar na citação acima - é a base da teoria sobre a meta-ficção.

Mas, o conceito de meta-ficção, não devemos única e exclusivamente a Bakhtin, ele está intimamente relacionado ao seu primeiro uso, a "metafísica":

Metaficción es, evidentemente, un neologismo, formado a partir de la preposición griega meta (meta) que significa "junto a, después, entre": detrás, más allá, en medio de. Como es sabido, su uso actual como raíz significante es de estirpe filosófica, y parte de una mera anécdota clasificatoria, mencionada en numerosas ocasiones por los historiadores de la Filosofía. Cuando Andrónico de Rodas hubo de ordenar los tratados de Aristóteles, nominó Metafísica a aquellos que, aunque diferenciados, estaban topológicamente detrás, más allá o en medio de la Física, aún cuando el mismo filósofo de Estagira se refiriese a esos mismos tratados como prima philosophia [...]. (OREJAS: 2003: 24)

Seria uma intriga romancesca se não fosse a mais prosaica ironia do destino. $\mathrm{O}$ termo "metafísica" surge, justamente, a partir da intromissão de um leitor / compilador na organização do texto aristotélico. É no mínimo curioso advertir que é na origem do termo metafísica que o leitor passa a ser o elemento chave para a estruturação da metaficção.

Não devemos, com efeito, prescindir do fato de que Bakhtin é, antes de tudo, um ávido leitor e que, primeiramente, não teoriza sobre as origens romancescas, mas sobre 
aspectos lingüísticos; em seus trabalhos, portanto, podemos vislumbrar uma inquietante busca pelas raízes clássicas dos termos, das estruturas literárias e da linguagem.

Não obstante as ponderações de alguns estudiosos, como Carlos Javier García, no sentido de chamar-nos a atenção para o fato de que o uso do prefixo "meta" é arriscado uma vez que contém "múltiples usos y acepciones" e que "en metafísica y metalenguaje su significado no coincide" (1994: 30), entendemos que tanto a metafísica como a metalinguagem e, por conseguinte, o metacriticismo se valem do procedimento reflexivo em sua constituição; conforme, mais uma vez, esclarece-nos Francisco G. Orejas:

Si $[\ldots]$ "metalenguaje es el lenguaje que se habla de un lenguaje, de este modo convertido en objeto de investigación", la metafísica es aquella arte de la filosofía que estudia el ser en cuanto ser, pero constituida como prima philosophía y, por ello, implicada en la reflexión de primer nivel sobre la ciencias - en el sentido aristotélico - o filosofías "particulares": se trata de una filosofía de la filosofía, de primer nivel pero, y por esa misma razón, de segundo grado. E1 propio Aristóteles, en la Metafísica, que se inaugura con el célebre postulado relativo a que "todos los hombres tienen naturalmente el deseo de saber", define la filosofía primera, la metafísica, como "ciencia teórica de los primeros principios y de las primeras causas"; es decir, ciencia de las ciencias (filosofías) de principios $o$ particulares, evidente correlato del metalenguaje concebido como lenguaje que se ocupa de otros lenguajes particulares o lenguajesobjeto. (2003: $26-7)$

Ainda que o termo "metafísica" tenha se difundido ao longo do tempo, principalmente durante o Renascimento, o uso de outros termos relacionados ao prefixo "meta" (meta-ficção, meta-teatro, meta-política etc.) - não obstante o uso do termo metacriticismo e do conceito de "meta-narrativa" que Bakhtin faz em seus trabalhos já nos anos 30 sem necessariamente utilizar este termo - começam a surgir e a se difundir somente já bem entrada a segunda metade do século XX.

O termo "meta-ficção", não obstante seu conceito ser utilizado anteriormente por diversos estudiosos europeus, foi cunhado pelo norte-americano William Gass, em um 
ensaio do crítico publicado em 1970. É a partir deste ensaio que surgem outros estudos interpretativos acerca do termo e do conceito que se difunde amplamente no meio acadêmico.

À raiz "da ficção que se sabe ficção", portanto, surgem novos estudos que não se eximem de acunhar outros termos como literatura del agotamiento, de John O. Stark; novela autoconsciente, Robert Alter quem considera que o Quixote é o começo de uma revolução copérnica na prática e teoria da mimesis; a novela autogeneradora, de Steven Kellman; a sobreficción, de Raymond Federman; a novela reflexiva, de Michael Boyd; a antinovela, termo usado inicialmente por Sartre no prólogo à Portrait d'un inconnu, de Nathalie Sarraute; a aliteratura, de Claude Mauriac, quem dá um sentido favorável ao prefixo "a" do termo. Convém voltarmos às ponderações de Francisco G. Orejas tece a este respeito:

En cualquier caso, no estamos sólo ante una cuestión terminológica sino también, por así decir, topológica. La reflexión de los teóricos continentales no se limita a lo que podríamos considerar metaficción en sentido estricto, metanovela, novela autoconsciente, autogeneradora o reflexiva, sino que alcanza a un espacio más vasto y se sitúa en un horizonte más amplio, el del conjunto de las relaciones entre textos, que Mijail Batjin [sic] denomina polifonía o dialogismo, Roland Barthes metaliteratura, Julia Kristeva intertextualidad, Gérard Genette hipertextualidad y - cierto que más restrictivamente - Jean Ricardou y Lucien Dällenbach mise en abyme $^{13}$ o relato especular. (2003: 44)

Assim, podemos aferir que os estudos dedicados à "ficção que se autoreferencia”, ainda que inovem no termo que utilizam para se referirem à meta-ficção e não partam dos estudos realizados por Bakhtin, Lukács ou Benjamin, reforçam a idéia e

\footnotetext{
${ }^{13}$ Esclarecemos que o termo mise en abyme foi primeiramente usado por André Guide no Jounal 18891939. (apud OREJAS: 2003: 61).
} 
os conceitos que estes estudiosos já haviam desenvolvido ${ }^{14}$, como nos esclarece Julia

Kristeva:

Pero en el universo discursivo del libro, el destinatario está incluido únicamente en tanto que propio discurso. Se fusiona, pues, con ese otro discurso (ese otro libro) con respecto al cual escribe el escritor su propio texto; de suerte que el eje horizontal (sujetodestinatario) y el eje vertical (texto-contexto) coinciden para desvelar un hecho capital: la palabra (el texto) es un cruce de palabras (de textos) en que se lee menos otra palabra (texto). En Bajtín, además, esos ejes, que denomina respectivamente diálogo y ambivalencia, no aparecen claramente diferenciados. Pero esta falta de rigor es más bien un descubrimiento que es Bajtín el primero en introducir en la teoría literaria: todo texto se construye como mosaico de citas, todo texto es absorción y transformación de otro texto. En lugar de la noción de intersubjetividad se instala la de intertextualidad, y el lenguaje poético se lee, al menos, como doble. (1978: I, 190)

Seguindo os passos de Kristeva, em seus estudos sobre o romance a partir da teoria bakhtiniana, Gerárd Genette (1989: 9-17) em sua obra Palimpsestos: la literatura en segundo grado ${ }^{15}$, ampliará o conceito de intertextualidade para o de transtextualidade, estabelecendo, para tanto, cinco tipos de relações transtextuais. A intertextualidade, que se caracterizaria pela citação, plágio, cópia e alusão. A paratextualidade, que seria a parte pragmática essencial para a interpretação da obra e que se refere ao título, subtítulo, prefácio, prólogo, epílogo, notas, entre outros, e até declarações do autor relativas à obra. A metatextualidade, cujo paradigma é a relação entre obra e crítica. A hipertextualidade, ou seja, a forma lúdica como os artifícios e

\footnotetext{
${ }^{14}$ Não é nosso objetivo entrar na questão do "etnocentrismo" anglo-americano senão para assinalar que os estudos que começaram a serem desenvolvidos por seus pesquisadores já haviam alcançado, nos quarenta anos que antecedem o seu aparecimento, ampla difusão e aprofundamento nas pesquisas desenvolvidas pela crítica européia.

${ }^{15} \mathrm{O}$ subtítulo dado por Genette, entretanto, também faz uma clara referência ao trabalho de Barthes, $O$ grau zero da escritura (1953). Não nos esqueçamos que tanto Kristeva como Genette são discípulos de Barthes. Em seu estudo, analisando a obra de Mallarmé, este grande mestre francês assinala a destruição, ou ainda, a aniquilação da linguagem, cujo cadáver, em certa medida, seria a Literatura. De objeto do olhar, a linguagem passa ao plano do fazer e, logo, ao seu estado destrutivo e, naquele então (a obra é publicada em 1953) pondera o estudioso depois de atravessar todos os estados de solidificação, ela alcança o seu último avatar: a ausência, ou, "o grau zero da escritura". Notamos, portanto, um esforço de Genette no sentido de dar continuidade às ponderações de seu mestre e assinalar outros graus da linguagem na evolução da narrativa moderna.
} 
convenções do gênero e de sua tradição são urdidos através de uma hiper-consciência: as relações hiper-textuais se estabeleceriam entre um texto B - hipertexto - e um texto anterior A - hipotexto -, desta forma, a Odisséia seria o hipotexto da Eneida, por exemplo. E, finalmente, a arquitextualidade, na qual o jogo de palavras aludiria à relação com o conjunto de categorias gerais das quais depende o texto em sua singularidade.

A noção de meta-fiç̧ão - e por extensão meta-narrativa, meta-romance etc - de experiência, de intertextualidade, de mise en abyme e de todos os outros termos que se referem à "ficção que se auto-referencia", como podemos notar, radica naquela noção primeira expressa na origem do conceito de "metafísica". A do autor / narrador como leitor e vice-versa. Por outro lado, também afirma a noção do texto / contexto como mosaico de citações, conforme pondera Kristeva na citação acima.

É através deste mecanismo que se abre o jogo estrutural para que nós leitores compiladores - possamos atuar de forma deliberada na constituição da fabula ${ }^{16}$, uma vez que a trama também demanda a nossa experiência de leitura. Como nos esclarece Adorno:

Quando em Proust o comentário está de tal modo entrelaçado na ação que a distinção entre ambos desaparece, o narrador está atacando um componente fundamental de sua relação com o leitor: a distância estética. No romance tradicional, essa distância era fixa. Agora ela varia como as posições da câmara no cinema: o leitor é ora deixado do lado de fora, ora guiado pelo comentário até o palco, os bastidores e a casa de máquinas. $(2003,61)$

\footnotetext{
${ }^{16}$ Entenda-se por fábula "un tecnicismo que denomina la serie de las acciones que integran la historia relatada, no en el orden artificial en que aparecen en la obra (que es la intriga), sino en el orden cronológico artificial en que los hechos se encadenarían si en realidad se produjeran: Los formalistas rusos fueron los primeros en diferenciar fábula e intriga (o trama o argumento), considerando a la primera como material básico de la historia, y al argumento la historia tal y como era presentada por el relato, tal y como era contada. Al transformarse en argumento la materia prima de la fábula (Sklovski), adquiere una estructura narrativa artística que produce un efecto estilístico.” (BERISTÁIN: 1997: 207)
} 
Ao lermos uma obra e nos submetermos à leitura que o autor faz de outra(s) obra(s), estabelecemos na cadeia de re-leitura, um vínculo com a tradição, seja ou não ele de subversão; de certa forma não deixamos de concretizar o conceito de utopia borgiana, de uma Literatura em transfusão ab aeterno:

En el vocabulario crítico, la palabra precursor es indispensable, pero habría que tratar de purificarla de toda connotación de polémica o de rivalidad. El hecho es que cada escritor crea a sus precursores. $\mathrm{Su}$ labor modifica nuestra concepción del pasado, como ha de modificar el futuro. En esta correlación nada importa la identidad o la pluralidad de los hombres. (BORGES: 1989, II: 89-90)

Borges, antes de qualquer ponderação que possamos fazer, reforça neste fragmento a idéia que subjaz a todas as teorias aqui visitadas: a da concepção de que todos os autores são um único e que todos os livros não passam de um vasto Livro, o Livro infinito. Como Borges mesmo diz ao tomar "la declaración de Mallarmé: El mundo existe para llegar a un libro" (IDEM: 191), ou ainda, parafraseando Guimarães Rosa, para chegar a "O livro O”. 
"No sucedió en realidad, pero es probable que alguien se hubiera salvado alguna vez de sus cantos, aunque nunca de su silencio. Ningún sentimiento terreno puede equipararse a la vanidad de haberlas vencido mediante las propias fuerzas."

Franz Kafka, El silencio de las sirenas

Ulisses retornou repleto de espaço e de tempo.

Ossip Mandelstam

O canto das sereias é, ao mesmo tempo, aquela poesia que deve desaparecer para que haja vida, e aquela realidade que deve morrer para que haja literatura. O canto das sereias deve cessar para que um canto sobre as sereias possa surgir. Se Ulisses não tivesse ouvido as sereias, se tivesse perecido ao lado de seu rochedo, não teríamos conhecido seu canto: todos os que tinham ouvido tinham morrido e não puderam transmiti-lo. Ulisses, privando as sereias de vida, deu-lhes a imortalidade. E Homero, o aedo cujo canto é tão belo que o confundimos com o das sereias, pode contar-nos a sua história como se fossem elas a fazêlo.

Tzvetan Todorov, Poética da Prosa 


\section{Capítulo II}

\section{1 - A alteridade: do mythos ao logos, uma interpretação narrativa}

Para Adorno e Horkheimer a Odisséia testemunha a passagem do mythos ao logos. Esta afirmação, presente no estudo A Dialética do Esclarecimento (1985), não se restringe a um movimento intelectual ou ao período determinado em que foi escrita - a Segunda Grande Guerra. Tem um sentido muito mais amplo e radical. Para entendê-lo melhor, faz-se necessário resgatar o significado dos termos representativos dessa passagem.

Mythos e logos, em suas origens, pertenciam a campos semânticos adjacentes e se referiam ambos à palavra, à fala, ao discurso (VERNANT: 1992, 171/221): enquanto logos significava palavra, discurso, linguagem e, mais tarde, passou a ser traduzida por razão, a palavra mythos, por sua vez, designava uma modalidade característica discursiva, a do relato e a da narração. A primeira se firmou no âmbito da argumentação e a segunda no do discurso proclamado pelo poeta. Vejamos então como ocorre na referida obra homérica, a transição do discurso à argumentação, ou antes, do relato à razão.

Homero nos conta, no canto XII da Odisséia, que o astuto Ulisses, para ouvir o irresistível canto das sereias sem perecer, fez-se amarrar ao mastro de sua embarcação, instruindo seus companheiros a taparem os ouvidos com cera e a jamais soltarem as amarras que o prendiam. Durante a travessia, fulminado pelo en-canto abismal das sereias, o comandante gritou inutilmente aos companheiros para que lhe libertassem dos 
laços. É desta maneira que o lendário grego conseguiu se safar do até então invencível canto mitológico e pôde cantar, tal qual um aedo, sua peripécia aos feáceos.

Essa cena, memória ancestral de pujança simbólica vigorosa, alucina o estudioso com a polifonia interpretativa literária e filosófica que desencadeia e, ao mesmo tempo, impressiona pelo lugar comum que ocupa na cultura ocidental.

O lugar comum, como símbolo da travessia por excelência e da superação de adversidades para um merecido retorno ao lar, ganha envergadura quando se leva em consideração que é este o episódio divisor de águas da Odisséia uma vez que, a partir dele, Ulisses ganha voz narrativa e inicia, de fato, o seu regresso ao tão anelado lar.

Mas se por um lado este episódio se vincula a uma meta-narrativa, por outro e intrinsecamente ligado a ele, há um nítido afastamento do homem de sua devoção mítica em favor de sua individuação. Neste sentido a Odisséia se caracteriza como uma história de formação - Paidéia ou, em outras palavras, Bildung -, ao traçar o percurso de um herói cuja "experiência humana se desenrola num mundo temporal cujo limite último é a própria morte”. (COSTA: 2005, 25)

Seduzidos pelo canto de Ulisses, esquecemo-nos das Sereias e desviamos nossa atenção aos percalços e perigos de seu vagar. E as sereias, essas "musas da morte e do esquecimento" (HARTOG: 1996, 37)? Ao lado de Orfeu e dos argonautas, Ulisses é o único herói a escapar do poder mágico e mortal de seu canto. E elas, como reagem diante de seu fracasso $?^{17}$

\footnotetext{
${ }^{17}$ Adorno e Horkheimer $(1985,64)$ também nos chamam a atenção para este aspecto - como já tivemos a oportunidade de aludir no capítulo anterior -, referindo-se ao fato de que "É possível ouvir as Sereias e a elas não sucumbir: não se pode desafiá-las. Desafio e cegueira são uma só coisa, e quem as desafia está por isso mesmo entregue ao mito ao qual se expõe. A astúcia, porém, é o desafio que se tornou racional". Os estudiosos vêm neste ato a dialética da servidão e do sacrifício, uma vez que em Homero "arremessado" e "astucioso" são equivalentes, a astúcia é vista como "o desdobramento subjetivo dessa inverdade objetiva do sacrifício que ela vem substituir" $(1985,59)$ e assim, o herói a quem se destina a sedução, emancipa-se com o sofrimento $(1985,43)$, no ato de se fazer atar ao mastro e ouvir o canto sedutor das Sereias.
} 
A narrativa homérica, ao não se manifestar sobre o destino dessas mortíferas contra-musas (HARTOG:1996, 37), relega à tradição seu fim lendário: derrotadas, precipitaram-se ao mar. Mas o imaginário encantatório que a Odisséia deixou em aberto vai além:

O motivo das sereias assumiu na tradição mítico-poética formas, matizes e sentidos dos mais variados. Todo o imaginário que compõe o mito poético das sereias aparece ao longo dessa tradição sob a forma de enigma. A complexidade do mito e as suas variações e mudanças impedem, portanto, que se chegue a uma visão acabada. A própria representação das sereias transformou-se radicalmente, das figuras mais antigas de mulher-pássaro às imagens mais recentes e conhecidas de mulher-peixe. (COSTA: $2005,68)$

Esses temíveis seres da antiguidade perpassam a Idade Média para povoar o imaginário masculino em suas viagens desbravadoras marítimas e embelezar o cenário dos poemas épicos delas originados. E, ainda hoje, longe dessas odisséias marinhas, sua imagem ecoa em metáfora urbana de beleza física sedutora.

Mas, voltando ao plano narrativo, Ulisses "herda" o território discursivo ao implacavelmente silenciar as sereias e esta herança se legitima sob o signo do sacrifício. Sacrifício dialético que se converte em subjetividade: o canto que se eleva enaltece sua sobrevivência ao martírio e ao flagelo do corpo, duramente castigado que se submete, enfim, ao logos (ADORNO et HORKHEIMER: 1985), ao mesmo tempo em que confere ao esquecimento, ao menos discursivo, o devir das arrebatadas contra-musas.

Se a supremacia do sacrifício ulissiano no espaço narrativo evidencia a construção da cultura sobre os escombros da vida pulsional e da sujeição do homem, transversalmente relega a um segundo plano o sacrifício feminino. Instaurada a racionalidade civilizatória - o logos -, o homem se constitui como sujeito e configura a sua história como a de renúncia, sujeição e mutilação. 
[...] na inverdade da astúcia, a fraude presente no sacrifício torna-se um elemento de caráter, uma mutilação do herói astuto arrojado pelo mar e cuja fisionomia está marcada pelos golpes que desferiu contra si mesmo a fim de se autoconservar. (ADORNO et HORKHEIMER: 1985, 61)

Escolhendo de forma ilustrativa o fragmento da morte das sereias do poema homérico, os dois filósofos frankfurtianos trazem à luz que o "esclarecimento" diz respeito, antes de tudo, ao horror ao desconhecido e ao desejo de controlá-lo, ao medo diante da natureza e da morte e ao impulso de autoconservação, que estão na raiz da constituição do sujeito racional e da ordem civilizada. Seja da natureza, seja de si mesmo ou do feminino, a estratégia de conquista da subjetividade, portanto, é uma forma de sujeição racional. Neste sentido, constatamos que o logos masculino também emerge da usurpação do feminino. Se pensarmos em termos do legado cultural ocidental, esta sujeição racional também é uma característica marcante na narrativa brasileira.

Lucia Helena Vianna Carvalho (1990), em seu instigante estudo de doutorado, promove uma leitura da sujeição das figuras e das vozes femininas aviltadas e, muitas vezes, silenciadas ao longo das tramas romancescas.

Nos romances de autoria masculina as imagens representativas do feminino - significante da alteridade em relação ao masculino - ocupam o lugar de uma impossibilidade "Diadorim era o impossível", sentencia o texto de Guimarães Rosa. A seu modo, Madalena também, reafirma o texto de Graciliano. E assim Inocência e Iracema e Capitu... Nesses romances escritos por homens, a mulher é uma ausência, somente entrevista na Morte. [...] Como sempre vem associada a uma ameaça, a sua presença atrai um outro significante -a violência. Esta acaba voltando-se inevitavelmente contra a própria mulher que termina alijada, enterrada ou expulsa do romance, constituindo-se mesmo numa espécie de recalque cultural. (CARVALHO: 1990, 180)

Ao longo dos anos, como se pode notar, há um perdurar da cena das sereias silenciadas para que, como um paradoxo, ela possa existir literariamente sob a voz 
masculina enquanto metáfora de sua alteridade. Esta imagem diáfana, entretanto, é criteriosamente moldada ao timbre masculino que, diametralmente, entoa o seu réquiem. ${ }^{18}$ "Oblíqua e dissimulada", "bicho esquisito", "burra e estúpida", “impossível”: “a louca do sótão”. Em palavras de Lucia Helena (1990, 185) "tudo aquilo que em si mesmo eles não suportam reconhecer”.

Como nos mitos recriados a partir da Odisséia, esta translúcida imagem feminina, silenciada pela voz heróica viril, ecoa e se perpetua na polifonia de nossa memória discursiva, a ponto de se tornar uma das questões mais inquietantemente abordadas ao se tentar fundamentar uma crítica da literatura produzida por mulheres. Em outras palavras, tudo aquilo que em si mesmos eles não suportam reconhecer, reconhecer-se-á como a tônica da auto-afirmação da identidade Outra ${ }^{19}$. É curioso notar que alguns críticos, em seu julgamento inicial, não tenham conseguido separar os “domínios da arte" dos "domínios da vida", como podemos ponderar a partir das leituras feitas por Lúcia Castello Branco:

A idéia de ler o texto da mulher, buscando identificar ali traços que apontem em direção a uma especificidade da escrita feminina surge-me, a princípio, como uma inquietante provocação. Não há como manter o "distanciamento crítico" quando o objeto de análise corre o risco de se misturar ao sujeito, quando o corpus de pesquisa é um corpo flutuante em que é preciso tocar sem reter, interferir sem ferir. "Ver o sexo de minha mãe: isso me chocara. Para mim, não havia corpo que existisse menos do que o dela; mais ainda, não existia”, afirma Simone de Beauvoir diante da imagem da mãe semimorta. Como acercar-se da escrita feminina sem o sentimento constrangedor de algo muito antigo, muito familiar, que retorna, e a constatação de um estranho vazio que nos escapa e nos

\footnotetext{
${ }^{18}$ Um interessante paralelo é possível de se tratar a partir do estudo de Nicole Loraux, Maneiras trágicas de matar uma mulher: Imaginário da Grécia Antiga. Neste ensaio, a autora traça um perfil das personalidades e da imagem construída para as personagens femininas da tragédia grega, a partir da constatação de que nenhuma das personagens femininas morre em cena, sua morte ocorre antes, ocorre discursivamente através de um relato minucioso feito por alguma personagem ou pelo coro. Mais uma vez, a morte das personagens femininas, apesar de extremamente trágica, não ocupa o espaço cênico, é relegada a um segundo plano, no caso específico do drama da tragédia clássica, o discursivo.

${ }^{19}$ Consideramos ao longo do desenvolvimento deste subitem o estudo de Lucia Helena Carvalho (1990, 146-7), no qual a alteridade masculina é a identidade feminina. Portanto, Outro, com maiúscula, se refere ao feminino, à mulher, enquanto que outro, com minúscula, caracteriza a alteridade feminina masculina.
} 
arrebata como uma aparição? (BRANCO et BRANDÃO: 1989, 111)

Esta dificuldade se justifica, por outro lado, na medida em que a crítica sedimentada - em grande parte masculina e acostumada àquele universo -, incorria em julgamentos e afirmações visivelmente sectários ${ }^{20}$.

Por sua vez, Lucia Helena Carvalho (1990: 133, 174) recuperando e criticando este sectarismo expresso - difundido principalmente durante o século XIX sob a metáfora que as estudiosas Sandra Gilbert e Susan Gubar procuraram sintetizar como "louca do sótão" -, nos esclarece que:

A literatura produzida por mulheres nos últimos séculos, deixa ver, nas personagens dissonantes que põe em cena, o impulso feminino para livrar-se do confinamento social e literário, através de estratégias por meio das quais busca definir-se como "ser", capaz de pensar a arte e a sociedade.

A estudiosa nos alerta, ainda, ao fato de que a mulher-escritora, deixando de lado a crítica, ao se reconhecer tal qual sujeito narrativo, não mais identifica a falta que subjaz na consolidação do sujeito como uma castração - como nos tempos da reflexão freudiana. Ela, antes, reconhece nesta falta um vazio desde o qual se faz ouvir a sua voz e se abre "uma alternativa de discurso que se vem inserir nos jogos de linguagem da cultura do mundo" e, conseqüentemente, instaura a sua "condição de existência" (CARVALHO: 1990, 175).

Esta condição de existência abrange as mais variadas esferas - social, literária, mítica e cultural. Lucia Helena nos aponta, ainda, como exemplo máximo desta convulsiva crise de identidade da narrativa feminina, a obra de Clarice Lispector e problematiza a questão da re-construção da voz e imagem femininas, estabelecendo

\footnotetext{
${ }^{20}$ Lucia Castello Branco (BRANCO et BRANDÃO: 1989, 95) é quem nos esclarece tal conduta reiterada, ilustrando com o seguinte exemplo tomado da Literatura Portuguesa através dos textos de M. Moisés: "Vê-se que pode ser aproximada [Florbela Espanca] dos grandes sonetistas da língua (...), embora deles difira numa série de pontos (resultantes, no geral, de ser uma mulher de por isso cantar apenas o Amor)".
} 
como prisma de análise da obra da referida autora o romance Uma aprendizagem ou o Livro dos prazeres.

Vista a partir desta perspectiva, cabe salientar, a prosa feita por escritoras não se opõe a dos escritores. Se deixarmos de lado a infindável discussão sexista, que impõe ainda no séc. XXI para o nosso espanto - territórios literários e rótulo de domínio, percebemos que ao trabalharem o ponto de vista feminino de maneira desmistificadora e problemas narrativos cuja perspectiva se focaliza, muitas vezes, a partir do ponto de vista de uma personagem feminina, as escritoras ultrapassam um possível pejorativismo em benefício de uma conduta que amplia o caráter mimético literário, antes apenas reservado à perspectiva masculina.

\section{2 - O fio puxado da renda: a obra clariciana e a crítica}

A "renda" presente no título, não por acaso, remete ao enredo, à trama, à metáfora do outro feminino ${ }^{21}$ latente na Odisséia e, principalmente a esta, brilhantemente sugerida por Ana Maria Portugal e que pode ser aludida à crítica desenvolvida a partir da obra de Clarice Lispector:

E o que é a RENDA?

Não mais que uma linha, cordão ou fita, que contorna buracos, fazendo desenhos.

Com esse contorno desfilam flores, folhas, arabescos, gregas, uma infinidade de formas, mas o buraco continua lá.

E o que acontece se, por acidente, o fio é puxado?

Não sobra nada dos desenhos, apenas o fio. A renda, com seus desenhos, é devolvida, em sua condição de buraco, ao espaço vazio. (apud BRANCO et BRANDÃO: 1989, 141)

\footnotetext{
${ }^{21}$ Lembrando aqui, que o feminino representado por Penélope é aquele que complementa o masculino Ulisses, uma vez que não fere a ordem estabelecida.
} 
A importância da renovação narrativa trazida por Clarice é inegável, não obstante a dificuldade que se interpõe, desde o início, em enquadrá-la nos moldes préestabelecidos.

Alfredo Bosi (1997, 440-5), consciente das mazelas existentes entre crítica e teoria romancesca e seguindo a formulação de Lucien Goldman, cuja abordagem genético-estrutural do romance moderno pressupõe a dialética tensão entre o escritor $e$ a sociedade, levanta uma nova hipótese interpretativa para a narrativa brasileira.

Segundo Bosi, a tensão dialética presente em nossa narrativa, ou pelo menos nos romances produzidos de 1930 até o final da década de setenta - o ano da primeira publicação deste volume de Bosi é 1979 -, permite distribuir as obras “em, pelo menos, quatro tendências, segundo o grau crescente de tensão entre o 'herói' e seu mundo".

Através dessa visão, o estudioso enquadra os romances de Clarice Lispector e Guimarães Rosa, na quarta tendência, entre os "romances de tensão transfigurada", nos quais:

O herói procura ultrapassar o conflito que o constitui existencialmente pela transmutação mítica ou metafísica da realidade. (...) O "conflito" assim resolvido, força os limites do gênero romance e toca a poesia e a tragédia. $(1997,442)$

Em outras palavras, o "conflito" assim resolvido, em torno de uma única variável - o herói, ou antes, anti-herói romancesco -, coloca num mesmo campo interpretativo a duas produções narrativas bastante controversas, com enviesados universo crítico e gosto público, a de Guimarães Rosa e a de Clarice Lispector.

Consciente de que há outras variantes a partir das quais se poderia propor a leitura da narrativa brasileira - ambiente e ação, são os exemplos citados -, Bosi se justifica proporcionando-nos a possibilidade de contemplar a obra desses dois grandes narradores brasileiros, sob um prisma inovador. Por um lado, desde suas inovações 
unívocas, da ruptura e superação da "entidade" tipológica "romance" no cerne mesmo da criação literária. E por outro, a partir da interpretação polifônica que esta ruptura proporciona na transposição própria da autonomia autoral: da história coletiva rosiana e da individual clariciana. A aguda escolha da palavra transfiguração, referindo-se à tensão romancesca causada pela obra de ambos escritores, põe em relevo "uma fortíssima vontade-de-estilo que os impele à produção de objetos de linguagem a que buscam dar maior autonomia possível” (BOSI: 1997, 444 - todas os itálicos são tomados do texto).

Se Bosi vê a narrativa de Lispector como uma mimesis da "história individual", que projeta uma "transmutação mítica ou metafísica da realidade" provocada pela tensão entre o herói e o seu mundo, pontua também a trajetória do conflito inventivo de ruptura narrativa e a classifica como "mitopoética". Ora, são vários os estudos que vão à contramão desta afirmação e defendem uma desmitificação da narrativa clariciana, reiterando, em princípio, seu caráter parodístico e meta-ficcional com um uso apurado da linguagem, que a aproxima, de fato, da linguagem poética. Regina Pontieri (1999, 65), neste sentido, observa que este tipo de julgamento categórico decorre da escolha "de um centro de interesse a partir do qual se analisam as obras".

Lucia Helena Carvalho (1990), com efeito, defende criticamente em sua tese de doutorado que a fina ironia e a paródia são recursos recorrentes na obra de Clarice e, discordando das posições que toma Márcia Lígia Guidin (1990) quem em sua dissertação de mestrado os relega a um plano secundário, pontua que estes são os principais mecanismos usados em Uma aprendizagem.

As controvérsias interpretativas iniciadas já com a publicação de seu primeiro romance, Perto do coração selvagem (1944), de uma certa forma, tendem a persistir e, por sua vez e em alguns casos, a promover o desmantelamento de prestigiadas críticas e 
teorias. Parece ser esta a vocação e a provocação da obra clariciana. Como bem nos orienta Rosenbaum $(1999,153)$ "Teríamos que construir, para melhor abarcar a prosa moderna de Clarice Lispector, algo semelhante às concepções de Hugo Friedrich para a lírica da modernidade". Entretanto, parte dos estudiosos, numa atitude extrema, parece querer puxar o fio da renda crítica já constituída, para estabelecer um novo padrão interpretativo.

Recuperemos este fio pelo viés da estrutura romancesca. Uma das discussões, debatida à raiz da chave interpretativa da tradição estrutura romancesca surgida a partir do Quixote é a lançada por Carlos Fuentes (2000). Este ensaísta mexicano, ao traçar uma linha interpretativa dessa tradição na atualidade, posiciona dialeticamente a narrativa lusa e hispânica.

Por um lado, ele nomeia a tradição do romance moderno ${ }^{22}$ - cervantina - de $L a$ Mancha: a que "se sabe ficção e, mais ainda, celebra-se como ficção", cujo texto "não tem outra vida afora a de seu texto, feito à medida, em que é escrito e lido", que "diz o que ignoramos", é "reflexiva" e apresenta personagens que são "leitores ideais".

Por outro lado, denomina a outra vertente narrativa como sendo a de Waterloo: a que segue as correntes realista e de costume - de Balzac a Zola -, psicológica e naturalista - de Stendal a Tolstoi -, tão em voga na época. Em outras palavras, trata-se de uma literatura que "afirma-se como realidade", "oferece fatias de vida", "surge do contexto social", "lê o mundo" que focaliza e diz "o que já sabemos".

À tradição de La Mancha, Fuentes vincula Tristam Shandy, de Laurence Sterne (1713 - 1784), Jacques o Fatalista, de Denis Diderot (1713-1784) e Memórias Póstumas de Brás Cubas, de Machado de Assis (1839-1908).

\footnotetext{
${ }^{22}$ Ao citarmos ao longo desta tese o termo "romance moderno", estaremos seguindo os parâmetros de Carlos Fuentes, quem se vale da teoria e crítica literária, em boa parte hispanista e contemporânea, para considerar o Quixote, de Cervantes, como um marco para a instauração do romance produzido do começo do séc. XVI até a atualidade.
} 
Mas, em que medida a narrativa brasileira e, mais especificamente, a machadiana se beneficia da narrativa cervantina? Na medida em que ela também se sabe ficção e se torna o espaço da utopia ficcional, esclarece-nos Fuentes. É o caso da personagem Brás Cubas que, não apenas se sabe ficção, como vai além, auto-intitula-se "defunto-autor" e nós, de "leitores desocupados" do romance cervantino, passamos a ser o "verme" que rói "as frias carnes" do seu cadáver, ou seja, do romance. É com humor cáustico, traduzido pelos instrumentos cirúrgicos: "a pena da galhofa e a tinta da melancolia", que Machado nos coloca na condição de "vermes". É por isso que o nosso riso o é "nervoso", já que nos faz reconhecer nossa miséria no outro. Eis aí o nosso "legado".

A estratégia para tal aproximação - narrador-leitor - é estrutural. O narrador faz questão de nos incluir e excluir; é como leitores que nos vemos entre o arrebatamento catártico do desengano e o da "divina comédia" para a qual ele nos funcionaliza: "Não se irrite leitor com esta confissão" “(...) enfim eu escrevo as minhas memórias e não as tuas, leitor pacato".

Esse jogo dialético, escritor-narrador, na narrativa machadiana que se sabe ficção através do "diálogo explícito ou implícito entre o narrador e o leitor" (COSTA VIEIRA: 1998, 69), também se faz presente na obra de Clarice Lispector.

Cabe revisar que se trata de uma escritora já do séc. $\mathrm{XX}^{23}$ à qual Fuentes não se refere e que pensamos ser, mais do que pertinente, vinculá-la à tradição de La Mancha. $\mathrm{O}$ ato de vincular a narrativa clariciana à tradição de La Mancha, se por um outro lado preenche as possíveis lacunas deixadas por Bosi, por outro, permite que a filiemos a

\footnotetext{
${ }^{23}$ Fuentes se refere a Machado como escritor do final do XIX.
} 
uma tradição já presente na Odisséia, nos moldes, também, da leitura de Adorno e Horkheimer $^{24}$.

O recurso que grande parte da crítica da obra clariciana assinala como recorrente na obra da autora, como já tivemos a oportunidade de assinalar, é o da paródia, o mesmo recurso pelo qual são conhecidas a obra cervantina e a machadiana.

Neste sentido, Olga de Sá $(1993,19)$ nos esclarece que "a repetição reiterada e o paradoxo" também são recursos permanentes no estilo de Clarice Lispector que “constituem também armação estrutural de sua ficção". A partir desta constatação, a estudiosa estabelece dois pólos interpretativos para a análise de sua obra: o epifânico e o paródico. O primeiro serve, em palavras de Sá, “de transição ou passagem para a outra face da escritura clariciana", ou seja, para o paródico.

Já Regina Pontieri (1999, 71-2) estabelece, como "centro de referência" para a análise da obra clariciana, os conceitos de carne e quiasma de Merleau-Ponty. Estes conceitos - segundo a estudiosa que contesta o estudo de Sá - permitem ir além da "necessidade de estabelecer pontos de partida" - como é o caso da paródia, defendida por Sá - já que

(...) a realidade do par importa mais do que cada um dos lados. E é justamente esse, ao meu ver, o caso da obra de Clarice. Assim, $A$ Cidade Sitiada poderia ser o avesso de Perto do Coração Selvagem, que poderia ser o avesso de A Hora da Estrela, que poderia ser o avesso de Água Viva etc. Pois cada uma é somente um momento na constituição de uma escritura total que se faz, até certo ponto, como dinâmica de reversibilidade e jogo de diferenças. E cada uma leva em conta todas as outras para se erigir como singularidade.

Seja através da "parodia", seja através de uma "dinâmica de reversibilidade e jogo de diferenças", a forma estabelecida como ponto de partida para o estudo da

\footnotetext{
${ }^{24}$ E, também a Bakhtin, entre outros teóricos. Voltaremos a esta problematização teórica, de forma mais ampliada, no Cap.III.
} 
narrativa clariciana, ambas reforçam a estratégia que Fuentes aponta como característica da tradição de La Mancha: a ficção que se celebra como tal e que se auto-referencia ${ }^{25}$.

Já na primeira página de seu romance inaugural, Perto do coração selvagem (1944), Clarice sugere no ato de escrever à máquina a meta-linguagem da construção narrativa: a obra se escreve enquanto se lê. Conforme Alfredo Bosi $(1997,479)$ : “não há um começo definido no tempo nem um epílogo repousante (neste sentido é uma obra aberta, como aberta ao passado da memória e ao futuro do desejo é a corrente da consciência)".

Esse pólo paródico, como afirma ainda Olga de Sá, somente ganhará mais vulto a partir de seu terceiro romance $A$ cidade situada (1949) e atingirá seu amadurecimento com A Hora da Estrela (1977). Pontieri - como se pode notar na citação acima - lê esta estratégia ficcional como uma dinâmica de reversibilidade que acentua a peculiaridade de cada obra que constitui o todo.

Tal qual na obra cervantina - e também na machadiana -, um dos pontos de contato para que a ironia se efetive é o "complexo autoral" "26 a construção da estrutura autor-narrador em camadas como espelhos que se refletem mas que, não inadvertidamente, celebram-se como simulacros irônicos da trama ficcional estabelecida pela hierarquia do poder. Arguta metáfora da estrutura da sociedade.

Esta estratégia clariciana, também podemos vislumbrar em alguns de seus contos. É o caso de "Cinco relatos de um tema", publicado primeiramente no Jornal do

\footnotetext{
${ }^{25}$ Neste sentido, se na narrativa de Clarice, a obra posterior é sempre o avesso da anterior e vice-versa conforme nos afirma Pontieri - ou uma parodia da anterior - como nos afirma Sá -, a segunda parte do Quixote, a partir destes critérios, não poderia ser lida como uma paródia ou um avesso e vice-versa da primeira parte?

${ }^{26}$ Esta expressão foi utilizada, com relação à obra clariciana, por Daniela Mercedes Kahn $(2000,94)$ que analisando $A$ hora da Estrela em sua dissertação de mestrado, percebe que esta narrativa se configura em três níveis de autoria: "Clarice escritora - Clarice Lispector autora e personagem de Clarice escritora Rodrigo S. M. personagem de Clarice(s) e autor da história de Macabéa. Deparamo-nos portanto não com um autor e sim com um complexo autoral, cuja estrutura de camadas sobrepostas, denuncia a indiferenciação interna de sua organização, estabelecendo uma correspondência perfeita com a estrutura do universo ficcional."
} 
Brasil (26/07/1969), nome com o qual também aparece na coletânea póstuma $A$ Descoberta do Mundo (1984). Entretanto, aparecerá como "A Quinta História", em $A$ Legião Estrangeira (1964) e Felicidade Clandestina (1971).

Trata-se, na verdade, do desdobramento das formas de narrar e interpretar o narrado. A tessitura se compõe da história de uma mulher que envenena baratas, a história que conta a história da mulher que envenena baratas e as possíveis formas de se narrar e de se ler esta história. Há desde o início, uma articulação perfeita entre conteúdo e forma, linguagem e metalinguagem, narrativa e meta-narrativa neste conto que, à medida que se faz contar, também se propõem como leitura.

O modelo invocado, logo de início, ao igual que no texto cervantino, também é um modelo árabe, nesse caso o das Mil e Uma Noites: "Embora uma única [historia], seriam mil e uma, se mil e uma noites me dessem". O duelo da palavra com a morte, enquanto narrativa ficcional que se eleva à condição de realidade, ganha nova dimensão no texto de Clarice: se para Scherazade cada narrativa representa um adiamento da morte, a narradora de "A Quinta História" sabe que sua palavra é incapaz de deter a marcha inexorável do tempo, elemento este, entendido como o da experiência narrativa e narrada. Por tanto, se o conto se conclui, condena-se à morte.

Por esta razão, esta narrativa se anuncia como uma subversão da ordem e da lógica narrativa do conto convencional. Ela ficcionaliza o leitor como personagem e ao evidenciar a distinção entre "o eu que vive a história", “o eu que relata a história" (KAHN: 2000, 25 - negritos do texto) e o eu que a interpreta, ainda que estas esferas possam representar a mesma pessoa, elas também se constituem em um avatar espacial, uma vez que este se caracterizam como o território ideal de constituição / construção da ficção. Não obstante todas estas manobras, o leitor - elemento da terceira esfera - tem 
mobilidade interpretativa e, além disso, tem poderes no sentido de indicar o destino da narração.

Os limites da experimentação dos elementos intrínsecos a uma narrativa - autor, narrador, personagem, tempo, espaço, leitor -, estabelecidos pelo primeiro romance moderno, o Quixote ${ }^{27}$, neste conto de Clarice Lispector se traduzem através da discussão da crise dos limites da própria ficção. A intervenção do leitor-narrador, esfera lábil, tem um propósito que vai além do estético, uma vez que prepondera, como resultado, a liberdade que se vislumbra na história que está por vir, completada pelo inconcluso, pela impossibilidade, ou ainda, pelas possibilidades que cada leitor lhe dará. De fato, parábola utópica dos limites lábeis de produzir e apreender a esfera receptiva da ficção, ou ainda, das camadas sociais.

O leitor, arrastado pelas manobras discursivas ao interior do texto, divide-se entre o magnetismo proporcionado pela narrativa que o ficcionaliza e o olhar crítico do que se lhe apresenta. É sabido que todo texto literário pressupõe um leitor. Clarice, em sua meta-narração, deixa explícita a função que o leitor ocupa em toda sua obra.

\footnotetext{
Como Vieira $(1998,29)$ assinala, "Clarice Lispector estabelece um cruzamento entre o fazer literário e a existência humana, revelando o que há de comum entre eles sem, entretanto, desviar seu olhar do cotidiano". É deste entrecruzamento que surge a preocupação clariciana com a recepção. O leitor, sob a ótica da própria autora, ocupa uma condição de elemento narrativo - um outro ${ }^{28}$, elemento representativo da alteridade - que, recebendo o texto, não só influenciará o seu fazer literário, mas também será o ponto fulcral da epifania narrativa:
}

Outra coisa notei: basta eu saber que estou escrevendo para um jornal, isto é, para algo aberto facilmente por todo mundo, e não para um livro, que só é aberto por quem realmente quer, para que, mesmo sem sentir o modo de escrever se transforme. (LISPECTOR: 1984, 156)

Este fazer literário, que evolui sob o signo da metalinguagem, à medida que se constrói transversalmente confunde-se com a própria construção da personagem e

\footnotetext{
${ }^{27}$ Seguimos ainda o raciocínio de Carlos Fuentes.

${ }^{28}$ Esclarecemos que as considerações sobre "alteridade" utilizadas por Maria Helena Carvalho e referidas na nota de pé de página número 3 referem-se ao contexto ali tratado. Ao referirmos ao "outro" dentro da estrutura narrativa que analisamos ao longo desta tese, temos como pressuposto um "outro eu" sem marcas sexistas e que não está em posição de voz atuante, mas que, decisivamente, influi na sua concretização.
} 
se deixa arquitetar pela interpretação do leitor. Assim como os conflitos das personagens "muitas vezes são superados por questões pertinentes ao fazer literário" (VIEIRA: 1998: 33), a efetiva superação apenas se dará com a anuência do leitor: é a ele a quem cabe preencher os vazios, ou antes, dar sentido aos silêncios que permeiam a obra. É a ele, por exemplo, a quem compete dar sentido á dialética presente já no título de Uma aprendizagem ou os Livros dos Prazeres (1969). Em outras palavras, dar sentido à odisséia monológica ou dialógica(mente). Assim posto, esta odisséia, com efeito, transforma-se em construção narrativa e formação da personagem - bildungsroman -, e ambas somente se efetivam por meio de um leitor ativo.

Apesar de a crítica de então já manejar com gosto a teoria da "obra aberta" de Umberto Eco (CARVALHO: 1990, 152-3), quando Clarice Lispector publica Uma aprendizagem agita e divide as opiniões. O romance que começa inusitadamente por um vírgula e termina com dois pontos - uma ruptura visível a qualquer regra ou convenção, o que confere uma abertura inconteste à obra -, provoca um certo desconforto numa tendência que "ora voltando-se para a análise comparativa dos textos de Clarice com os de Joyce, ora lançando-se nas projeções metafísicas de base heideggeriana", "não deu relevo à questão crucial desse livro que ousa desnudar de maneira radical a intimidade profunda da mulher". (CARVALHO: 1990, 153)

Mais que desnudar a intimidade profunda da mulher, este romance clariciano desnuda e reverte a intimidade profunda da estrutura romancesca, parodiando ou fazendo uma leitura do avesso das convenções teóricas, do mito e da mimesis.

\section{3 - Um romance que é "o meio do caminho"}


A maneira descontínua de narrar e a força poética de Clarice Lispector são atributos que, conferidos ao seu romance inaugural (NUNES: 1989, 11), recriam-se a medida e proporção de uma reinvenção contínua de aprofundamento arrebatador na densidade psicológica e na estrutura romancesca.

Como Scherazade, a encantadora e hábil narradora das Mil e uma noites, e Ulisses que, além de cantar tal qual um aedo as suas peripécias prende a atenção do ouvinte-leitor, a personagem-narradora clariciana nos envolve e nos enreda através da sedução de seu relato e do encanto de seu discurso. A respiração de sua narrativa e o seu vigor poético, assim postos, revelam-se como uma estratégia que preconiza o momento certo da pausa e da interrupção, da retomada e do recomeço, a habilidade para imprimir o ritmo exigido pelo contado, a manutenção cautelosa do tempo no cerne de sua convenção, a interrupção que alimenta o desejo pela continuidade ao mesmo tempo em que adia a morte, ou antes, o final do romance. A arte de narrar e a discussão existencial que ela promove, guardam grandes afinidades com a astúcia - a metis dos gregos -, a mais famosa qualidade de Ulisses e de Scherazade.

Estas qualidades de narradora exímia também ecoam de forma arrebatadora na operação polifônica. Portal de entrada para Uma aprendizagem, o fragmento IV, I do Apocalipse nos abre um "universo", cujo tema não é particularmente bíblico, perpassa uma tradição literária ocidental de diametrais périplos de subidas ao céu e descidas ao inferno.

Esta referência se torna mais pungente na medida em que o nome do personagem que conduzirá a odisséia narrativa é idêntico ao do mítico argonauta, Ulisses. Este herói da conhecida epopéia grega que, fadado a naufragar pelos mares desce ao inferno para conquistar a volta ao seu tão anelado lar, na narrativa clariciana, converte-se em um professor de filosofia universitário. 
Consciente de sua herança do logos que emerge da usurpação do feminino, o Ulisses clariciano se redime impulsionando a odisséia feminina de formação - bildung na medida em que descobre e aceita a sua própria alteridade - tudo aquilo que em si mesmos eles não suportam reconhecer -, em uma heroína que tem nome de sereia, Loreley.

O "inferno" ao qual esta contra-musa empreende sua viagem, todavia, é muito mais tangível. É o aprofundamento nas entranhas do ser: Ulisses propõe como ponto de partida, que Loreley busque a resposta à pergunta mais temível que se possa fazer-se: quem sou eu?

O tema da viagem de conhecimento, inspeção e descoberta alcança na literatura de nossa língua releituras emblemáticas e mais acordes a subidas ao paraíso, que a descidas ao inferno. Um de seus momentos fulcrais de caída às profundezas do Ades está no canto X de Os lusíadas.

Já no poema drummondiano “A Máquina do mundo” essa possibilidade se abre ante a perplexidade do leitor de forma silenciosa, em meio às montanhas mineiras e, paradoxalmente, transmite um tom de desencanto "sem deuses nem mitos (só a memória destes), mas nem por isso menos enigmático e temível" que aquele que se apresentava no canto camoniano (BOSI: 2003, 110).

Em ambos poemas, segundo Alfredo Bosi (2003, 110), a relação do “eu” com o "outro" alcança uma tensão visível que se funde com o indizível e o entredito, que lançam ao leitor a sua concretização.

Nos versos do poeta brasileiro, entretanto, se nos oferta a possibilidade do vislumbrar em meio a um continuum. O "eu" está caminhando e pára. Tal como no romance clariciano, como leitores, ingressamos num momento sugerido. No poema drummondiano ele se apresenta através da conjunção aditiva “e”, que inicia o primeiro 
verso, sugerindo - calando o "antes"? - a busca por um começo. Neste suspense, o "eu" se depara com a "máquina" que se abre. Temos a oportunidade de vislumbrá-la através de suas "retinas fatigadas de tanto mentar". Não obstante, seu poder de atração é tamanho que parece que sua aparição já se significa como silêncio na perplexidade do sujeito que a contempla. O "eu" drummondiano, contudo a repele e volta ao seu vagar. Em contrapartida, não é o que à primeira vista acontece no romance clariciano uma vez que a máquina se abre através também de um continuum, representado pela vírgula seguida de um verbo em gerúndio e nós, leitores, é que somos os espectadores. Detenhamo-nos na narrativa clariciana ${ }^{29}$.

Se Uma aprendizagem ou o Livro dos Prazeres se significa, estruturalmente, nos e entre dois silêncios, estes silêncios, entretanto, não apenas se caracterizam pelos possíveis significados que adquirem esses dois pólos estruturais, mas também estão presentes ao longo da narrativa tal qual a máscara representativa da górgona: revelandose, latentemente, em formas diversas.

É no meio desta trajetória - por assim dizer, experimental, ou ainda, de experimentação para a concretização ou não do universo romancesco - que o leitor se transforma em elemento narrativo - personagem? - que lhe ditará uma das opções presentes no desafio esfíngico do título: Uma aprendizagem ou o Livro dos

\section{Prazeres?}

\footnotetext{
${ }^{29}$ Lúcia Helena $(1991,26)$ também faz referência ao "sentimento do mundo" que, a seu ver, transparece no volume de contos Laços de Família; segundo seu ponto de vista, Lispector fixa no referido volume "uma camada específica de sensibilidade pequeno-burguesa figurada no embate com as representações de poder inconscientemente internalizadas e tornadas institucionais". Ao comparar o relato clariciano ao poema drummondiano, não temos senão a intenção de perceber a prosa poética clariciana que, ao nosso ver, aproxima-se à poesia drummondiana numa referência (in)direta e, assim, inseri-la no contexto da tradição temática literária da alteridade. Esperamos, a partir desta característica, enriquecer nossa análise. Cabe-nos, neste momento pontuar uma vez mais que, outra possibilidade de influxo que vemos aqui é o da narrativa joyceana. Entretanto esta, ao subverter a cronologia se desmorona por um abismo narrativo cuja estrutura também corrobora a constituição mesma do sujeito, enquanto que na narrativa clariciana, começamos pelo abismo interior, que se estrutura a medida em que a personagem também vai se encontrando e encontrando o outro. Benedito Nunes $(1989,79)$ assinala que o experimentalismo de $A$ Paixão segundo G.H. iria ao encontro da narrativa joyceana enquanto que Uma aprendizagem, a contramão uma vez que a narrativa "oscila entre unidades monologais e unidades dialogais".(itálicos do texto).
} 
O leitor (ECO: 1986), enquanto elemento, constitui-se como aprendiz - leitor crítico - ou um mero leitor passivo - ou ingênuo - que acompanha a personagem principal e, por esta razão, é responsável pela concretização ou não da opção de prazer referido no título. A epifania corresponderia, portanto e em última instância, a um elemento de catarse narrativo, o que se constitui estruturalmente em uma esfera triádica lábil: narrativa-personagem-leitor ${ }^{30}$. Vejamos como esta esfera se dinamiza ao longo da narrativa.

A "aprendizagem", referida no título em forma de unidade - "Uma aprendizagem" -, se em um primeiro momento parece ser a base dessa união triádica, o jogo discursivo da aprendizagem - do monólogo ao diálogo no texto enquanto estrutura narrativa, do preenchimento dos vazios que o leitor terá que fazer, como vértice destinatário da aprendizagem -, ensaio joyceano às avessas, corrobora $\mathrm{o}$ aprofundamento introspectivo necessário à busca interior, às perguntas latentemente existenciais.

Como assinala Benedito Nunes, esse maniqueísmo, que aqui caracterizamos como triádico, é um artifício narrativo clariciano recorrente. De Perto do coração selvagem a O livro dos prazeres é possível vislumbrá-lo no jogo dialético contínuo, ou ainda, na dianóia do Eros filosófico narrativo:

\begin{abstract}
"Autoconhecimento e expressão, existência e liberdade, contemplação e ação, linguagem e realidade, o eu e o mundo, conhecimento das coisas e relações intersubjetivas, humanidade e animalidade, tais são os pontos de referência do horizonte de pensamento que se descortina na ficção de Clarice
\end{abstract}

\footnotetext{
${ }^{30}$ Rosenbaum (1999: 98 - negritos nossos) pensa em uma relação similar ao estabelecer um centro de interesse a partir do qual analisa parte da narrativa clariciana e, com efeito, afirma "O exercício de crueldade, nos textos de Clarice Lispector, evolui de modo a enredar as personagens e a própria narrativa em jogos perigosos, onde a fruição de prazer se mescla aos movimentos destrutivos do sujeito e da palavra. Daí privilegiarmos na abordagem da escrita clariciana a categoria do sadismo, certamente sem nela esgotar seu amplo espectro temático e discursivo, mas tendo como pano de fundo das análises o aproveitamento literário dado às relações sádicas na tríade leitor-texto-personagens".
} 
Lispector, como dianóia intrínseca de uma obra na qual é relevante a presença de um intuito cognoscitivo, espécie de eros filosófico que a anima. (NUNES: 1989, 99 - itálicos do texto)

Os "pontos de referência do horizonte de pensamento" aos quais se refere Nunes são a base latente existencial desta estrutura narrativa: o monólogo inicial se caracteriza pela pulsação do fluir, "respirar discursivo" de consciência da personagem principal em sua odisséia introspectiva.

Se a erupção discursiva inicial transborda como a transposição do mundo interior da personagem, como apontado pelo estudioso; notamos também que se estrutura através de uma montagem escrupulosa do caos e é neste sentido que, ao nosso ver, aproxima-se da poesia lírica moderna.

Cabe elucidar que esta interpretação de Uma aprendizagem ${ }^{31}$, já rendeu algumas reflexões. Lúcia Helena $(1991,37)$ lê que esta erupção monológica inicial se aproxima mais a um "insight poético" que a uma narrativa propriamente dita. Daí sua explicação para o fato de criticarem esta obra por sua "escrita desigual". Mas a forma, na obra clariciana, significa-se como conteúdo. A pontuação que $U A$ apresenta inicialmente é "singular" e significativa, como se expressasse a cadência poética ${ }^{32}$ (travessões, dois pontos etc.). Os espaços em branco entre as linhas e os pensamentos cuidadosa e pretensamente (des)ordenados servem como mecanismo para insinuar hesitação, pausas, enfim, silêncios significativos que algumas vezes se verbalizam através da inclusão referências explícitas - ou exclusão - referências implícitas.

\footnotetext{
${ }^{31}$ De agora em diante, para melhor fluidez do texto desta tese, utilizaremos a sigla $U A$ ao referirmos a Uma Aprendizagem ou o Livro dos Prazeres e aludiremos ao número da página citada. A edição utilizada é a Rio de Janeiro, Rocco, 1998.

${ }^{32}$ Em advertência, Lispector escreveria sobre sua escrita: "A pontuação é a respiração da frase, e minha frase respira assim. E se você me achar esquisita, respeite também. Até eu fui obrigada a me respeitar" "Ao Linotipista" in A Descoberta do Mundo, p. 89.
} 
A linguagem de $U A$, com efeito, recria a vivência emocional nas escolhas sintáticas e semânticas e, neste sentido, ela "toca a poesia e a tragédia" (conforme já ponderado e citado anteriormente - 1997, 442).

Entretanto, para o entendimento deste "mosaico" narrativo, a astúcia do leitor é requisito indispensável. Cabe a ele a comunhão com esta pulsão etérea das palavras:

(...) rainha egípcia? não, toda ornada como as mulheres bíblicas, e havia também algo em seus olhos pintados que dizia com melancolia: decifra-me, meu amor, ou serei obrigada a devorar, e agora pronta, vestida, o mais bonita quanto poderia chegar a sê-lo, vinha novamente a dúvida de ir ou não ao encontro de Ulisses - pronta, de braços pendentes, pensativa, iria ou não ao encontro? (17-negritos nossos)

A simultaneidade de idéias que a narrativa imprime, como se fosse elemento de ruptura da coerência, aliada aos pretensiosos descuidos coesivos discursivos, não apenas exigem do leitor uma sintonia, que o impacta num primeiro momento, mas sobretudo, confere-lhe uma autoridade de condutor dos significados, com a finalidade de conferir certo sentido aos vazios que, convenientemente, operacionam a forma da estrutura narrativa ao mesmo tempo em que atua como o elo lábil de alteridade funcional do leitor.

No fragmento acima, a mistura de imponência, castidade e vulgaridade, feita através da apresentação de imagens significativas - "rainha egípcia", "mulheres bíblicas" e "olhos pintados", respectivamente -, sugere vários sentimentos contraditórios pelos quais passa a personagem. No entanto, apenas um deles nos é revelado explicitamente: melancolia ${ }^{33}$, acrescentando-lhe um outro significado ao olhar

\footnotetext{
${ }^{33}$ Convém já aproveitar o fragmento citado de Benedito Nunes e também assinalar que o acréscimo se deve a uma "diferenciação de temporalidade". E como o crítico bem assinalou, o "tempo" é um dos pontos fulcrais na obra de Lispector. Entretanto, cabe aqui colocar em relevo que a estrutura narrativa também é uma posta em cheque da temporalidade enquanto constituição do sujeito. O que interessa é o presente em detrimento do passado e do futuro, conforme veremos mais adiante.
} 
enigmático da esfinge, mas sem a perda de seu significado inicial, acentuando-lhe, antes e ainda mais, a característica silenciosa; a conjunção "e" em suspenso - que proporciona uma "desigualdade rítmica" em palavras de Benedito Nunes, em palavras de Lispector, prepondera a "respiração da frase", ou seja, a antromorfização da estrutura -, deixa em suspenso, ao leitor, o significativo silêncio de seus pensamentos ou suposições de pensamentos alheios, abismo este interrompido pela volta a uma realidade material exterior, a ação concluída durante o divagar: "agora pronta, vestida".

Mas a imagem hesitante, sugerida na estrutura narrativa que $\mathrm{o}$ fragmento apresenta através de uma atropelada descrição, é apenas um dos avatares que se multiplicam ao longo da narrativa e que se concentram principalmente na primeira parte, quando Loreley, a argonauta principal, confronta-se com Ulisses, sua alteridade masculina em "Mais uma vez, nas suas hesitações confusas"(18).

Esta primeira parte da narrativa, conveniente e previamente denominada " $\mathrm{A}$ Origem da Primavera ou A Morte necessária em Pleno Dia”, põe em relevo a fase em que se encontra a personagem - momento de transformação - e, tal qual a dicotomia presente no título da obra, oferece-nos uma outra possibilidade interpretativa. Quem assinala esta tendência ao "contra-canto" em "tom menor" é Olga de Sá $(1993,20)$, quem aponta que tal qual Cortázar, Clarice desgasta "a linguagem, denunciando o ato de escrever" e neste trabalho tanto "o ato de escrever como o ato de ler são questionados, (...), em agoniado confronto com o ser e o viver."

Este confronto, como indica a estudiosa, já se faz presente no título de suas obras de forma contrastiva, ao que ela imprime a feliz denominação de "contra-canto" 34 .

\footnotetext{
${ }^{34}$ Sá chama a atenção para a presença de uma especificidade que causa ao leitor, já no título, um certo estranhamento. Há já a intencional precisão daquele "tom menor". Alguns dos exemplos são: A cidade / sitiada, A maçã / no escuro. Embora a estudiosa cite Uma aprendizagem / ou o livro dos prazeres, com essa especificidade divisória para comprovação de sua teoria. Ao nosso ver, o paradoxo, ou antes, o "contra-canto" em palavras da autora, alcançaria no título da obra que estamos analisando dois níveis de disjunção.
} 
Esta designação, simular à de François Hartog (1996) para nomear o canto das sereias, ao nosso ver reforça, neste romance clariciano, o caráter de subversão do modelo de sujeição instituído, como vimos, pelo modelo clássico.

Se por um outro lado o título Uma aprendizagem ou o Livro dos prazeres apresenta uma disjunção, passível de ser interpretada como uma adivinhação, a resolução deste enigma, ou ainda, a decisão por um dos semas é um ato que compete ao leitor resolver. Com efeito, é neste jogo dialético que já de início percebemos o vazio, o silêncio que cobra uma solução.

Nos moldes de análise de Sá $(1993,173)$ é que, de forma mais deliberada, esta disjunção ganha um outro sentido na medida em que a estudiosa a correlaciona a um canto primeiro: O livro / dos prazeres - paródia talvez de O cântico / dos cânticos. Lembremos que, o livro bíblico que consagra o amor erótico é, por esta razão, também uma audível dissonância presente entre os demais relatos sagrados.

No entanto, não percamos de vista que Benedito Nunes avalia que este romance também se constitui na e

"[...] pela variação do discurso indireto, com sua desigualdade rítmica e seu espaçamento, aquela e este correspondendo a uma diferenciação de temporalidade, desde $\mathrm{o}$ passado remoto $\mathrm{e}$ impessoal, de onde a personagem vem, ao passado próximo de um acontecimento que a instala em sua intimidade pessoal [...]."(1989, 80 - negritos nossos)

Se esta "desigualdade rítmica", como já tivemos a oportunidade de apontar a partir das palavras da própria autora, reflete uma manobra discursiva que viabiliza a esfera lábil do jogo discursivo da aprendizagem, por um outro lado, esta cadência rítmica é a identidade da narrativa que a faz destoar ${ }^{35}$ dos seus demais livros. Ressaltemos, ainda, que é este jogo que propicia a realização - ou não - da epifania do

\footnotetext{
${ }^{35}$ Estamos pensando aqui, também, numa reinvenção do discurso narrativo a partir dos seus pares, levando em consideração conceitos paródico (Sá) e de carne e quiasma (Pontieri).
} 
prazer. Portanto, o traço de indecisão da personagem se instaura semanticamente na narrativa enviesada pelos seus pensamentos que, como outro ponto de desequilíbrio em convivência com a sua percepção no começo do romance, viabiliza a aprendizagem ou a leitura do livro.

Neste sentido, se o cronotopo se instaura, inicialmente, no movimento da tessitura rítmica do leitor que acompanha e arma a partir do fluir de consciência de Loreley, este movimento espaço-temporal atinge um caráter lábil e duplamente subjetivo: as marcas temporais representativas da constituição da narrativa abarcam, também, a constituição de um sujeito narrativo e a percepção do leitor em si, enquanto sujeito atuante nesta função. Aquele, por sua vez, vive no limiar das fronteiras temporais (passado - presente - futuro) que muitas vezes se con-fundem e lhe impulsionam à estaticidade - o mesmo signo drummondiano que encerra "A Máquina do Mundo": de mãos pensas -, projetando-se em uma prece que entremeia "certo sensibilismo de tom romântico à entonação elevada e eloqüente, seguindo por um discurso de "faz de conta", retalhos de discursos de contos de fada"(CARVALHO: 1990, 154) cujas cadências rítmica e sonora, simetricamente, aproximam-nos do pulsar da personagem:

(...), faz de conta que ela não ficava de braços caídos de perplexidade quando os fios de ouro que fiava se embaraçavam e ela não sabia desfazer o fino fio frio, (16)

Esta propensão à estaticidade, que a personagem apresenta na sua relação discursiva monológica ${ }^{36}$ inicial, vai sendo superada por um delinear de fabulação, apesar das re-caídas estrondosas que aos poucos vão se transformando em hesitações silentes

\footnotetext{
${ }^{36}$ Pensamos ser esta a característica primeira que apresenta Loreley como um componente do jogo metanarrativo. Pensando na interpretação triádica que propomos para a análise da obra, esta seria uma preparação prévia para o leitor que também pretende, mas ainda está hesitante, realizar a aprendizagem.
} 
(...), ele dissera uma vez que queria que ela, ao lhe perguntarem seu nome, não respondesse "Lóri" mas que pudesse responder "meu nome é eu", pois teu nome, dissera ele, é um eu, perguntouse se o vestido branco e preto serviria,

então do ventre mesmo, como um estremecer longínquo de terra que mal se soubesse ser sinal de terremoto, do útero, do coração contraído veio o temor gigantesco duma forte dor abalada, do corpo todo o abalo - e em sutis caretas de rosto e de corpo afinal com a dificuldade de um petróleo rasgando a terra - veio afinal o grande choro seco, choro mudo sem som algum até que ela mesma, aquele que ela não havia adivinhado, aquele que não quisera jamais e não previra - sacudida como a árvore forte que é mais profundamente abalada que a árvore frágil - afinal rebentados canos e veias, então - (13-4)

O leitor crítico, atado a este mais que vislumbrar, a esta dinâmica de movimentos aos que auxilia na trama dos nós, que aparentemente não estão presentes ${ }^{37}$, forma o elo necessário para que o romance se realize e renasça a cada leitura, na “Origem da Primavera". Já o leitor passivo o relega à "Morte Necessária em Pleno Dia".

A prática da idéia de que o tecido do tempo é lacunar e a continuidade temporal é uma trama intrinsecamente relacionada à constituição do sujeito denota, antes de qualquer interrupção da leitura, que avançar é enfrentar ou adiar a morte.

Ao leitor de $U A$, inquieto e espantado, o narrador oferece em seu cronotopo, assim como o texto bíblico citado na epígrafe, uma espécie de "máquina do mundo" drummondiana. O texto se abre, enquanto narrativa, durante o tempo que lhe parece necessário para que nós leitores, qual espectadores privilegiados, observemos a trajetória do outro: um eu que se coloca em confronto e na posição de um outro.

Precipitar-se ao abismo do ser é arriscar-se a tomar a água de uma das fontes, a do esquecimento (Lethe) ou da memória (Mnemosyne). Uma Aprendizagem é a "Máquina do Mundo" que nos oferece esta possibilidade e, desta forma, impõe-se diante

\footnotetext{
${ }^{37}$ Salientamos, uma vez mais, que a dinâmica narrativa confere ao leitor um papel ativo na narrativa: é ele quem lhe imprimirá, decifrará tanto o "sentido" estrutural quanto o da constituição do sujeito (personagem). Desta forma, o leitor ao fazê-lo "poderá, 'num exercício de coragem', realizar suas próprias reflexões sobre sua vida; poderá, como ela [a autora], se analisar e se construir" (VIEIRA: 1998, 86), ou seja, realizar sua própria epifania.
} 
nós como "uma pedra no meio do caminho". O como sair desta experiência depende de nossa metis.

\section{4 - De Sereia a Penélope. Do canto à trama}

A odisséia de Loreley, em um primeiro momento como pudemos ver, alinha-se em razão do que se conta e da forma como esta ação se dá ao longo de sua jornada. A estrutura narrativa, por um outro lado, pauta-se também na construção do "ser", construção esta que se dá na configuração do tempo e do espaço da travessia na esfera lábil triádica (narrativa-personagem-leitor).

Neste sentido, sua trajetória, ao igual que a de Ulisses analisada por François Hartog (2005:16), importa menos como trajeto concreto e mais como "operador discursivo e esquema narrativo", como "resolução de um problema ou resposta a uma questão", uma vez que tempo e espaço são esferas lábeis representativas do fazer literário. Mas a questão, ou antes, as questões que a narrativa clariciana assim exposta suscita vão um pouco além das levantadas pelo estudo de Hartog sobre a obra homérica, uma vez que, $U A$ subverte as convenções em sua viabilização mimética, sejam elas no nível teórico, fabular ou mítico.

Como bem se sabe, toda reestruturação, todo deslocamento significativo, toda transição de um limiar - e, principalmente a proposta em $U A$, - reclamam a sua tradução e inovação em linguagem. Rosenbaum $(1999,153)$ nos chama a atenção para o fato de que o repertório de análise da obra clariciana "inclui termos como incomunicabilidade, desmontagem, paradoxo, obscuridade, deformações, desconcretização". A linguagem aqui tramada, além de apresentar todas essas tessituras como já pudemos vislumbrar, reflete uma urdidura aparentemente centrada na fabulação 
da personagem principal, Loreley. Esta personagem mimetiza, no nível da fabulação, o universo de uma mulher da burguesia agrária em decadência:

Também não dissera a Ulisses de como melhorara a penosa sensação de estar solta o fato de estar solta mesmo: o pai perdendo o grosso da fortuna, ela mudara-se sozinha de Campos para o Rio, comprara o pequeno apartamento onde vivia, sustentada regiamente pela mesada do pai. Com quatro irmãos homens, e ela filha única, o pai lhe mandava o que ela quisesse. Com um terço da fortuna que restava dava para eles viverem como ricos, mas felizmente para ela acabara-se a possibilidade de viajar sem parar pela Europa.(49)

Tivera cinco amantes e, na relação com todos eles, fora ela quem conduzira o enredar e o desenredar da relação. Ulisses aparece como a válvula propulsora para reverter esta situação. Mas como se não bastasse, a este fabular se soma o nome próprio das personagens que é, em si, uma aproximação vertiginosa a um outro nível, o amplo e rico universo da tradição mítico-narrativa. E as personagens, por sua vez, não desconhecem esta sua herança. Além de Ulisses, repetidas vezes, reconhecer em Loreley a sua ancestralidade ${ }^{38}$, é ele quem lhe revela sua essência:

- Loreley é o nome de um personagem lendário do folclore alemão, cantado num belíssimo poema por Heine. A lenda diz que Loreley seduzia os pescadores com seus cânticos e eles terminavam morrendo no fundo do mar, já não me lembro mais de detalhes. Não, não me olhe com esses olhos culpados. Em primeiro lugar, quem seduz você sou eu. Sei, sei que você se enfeita para mim, mas isso é porque eu já seduzo você. E não sou um pescador, sou um homem que um dia você vai perceber que ele sabe menos do que parece, apesar de ter vivido muito e estudado muito. (97)

\footnotetext{
${ }^{38}$ Acrescente-se o fato de Loreley, como já tivemos a oportunidade de assinalar, comparar-se às mulheres antigas, Ulisses também o faz quando a compara à sereia heiniana, ou quando vê nela rasgos antigos, como nas páginas 58 ("Você é tão antiga"), 89 ("Teu rosto, Lóri, tem um mistério de esfinge: decifra-me ou eu te devor") e 98 ("Você é uma mulher muito antiga"). A narrativa também resgata esta faceta de nossa personagem na descrição que aprensenta após seu primeiro banho de mar: "Já não precisa de coragem, agora já é antiga no ritual retomado que abandonara há milênios.” (79)
} 
Ao passo que o narrador onisciente ${ }^{39}$ também resgata a imagem ancestral ulissiana, sob os olhos de Loreley:

Lóri só tinha um medo: de que Ulisses, o grande Ulisses cuja cabeça ela segurava, a decepcionasse. (145 - negritos nossos)

Esta composição em camadas, ao reiterar a característica de construção mise en abyme da narrativa clariciana - como já tivemos a ocasião de mostrar com relação aos níveis da narrativa e interpretação, nos quais esta particularidade se evidencia por meio de uma transposição triádica -, no nível fabular e mítico, como não poderia deixar de ser, adquire outra forma exemplar de construção. O mise en abyme aqui se esboça na medida em que a constituição de ambas personagens se conduz pelo que suas próprias referências narrativas míticas trazem ao texto, ao mesmo tempo em que as desconstrói como tais.

O mito da sereia Loreley surgiu em 1801, quando Clemens Brentano, tido como o "pai" da beldade loira, relatou pela primeira vez sua história durante uma viagem pelo Reno. Mas ao que parece, foi Heinrich Heine quem definitivamente a imortalizou em seus versos. A Loreley de Heine é uma moça de uma beleza sobrenatural que, abandonada por seu amado, passou a seduzir mortalmente com seu canto de lamento a todos que dela se aproximavam. Condenada por esta razão a viver reclusa, três cavalheiros foram incumbidos a levá-la a um convento distante. No caminho, entretanto, Loreley se detém imaginando ver seu amado que regressava e se precipita de um rochedo ao Reno. Desde então, como implacável sereia, aparece no alto do rochedo que leva seu nome e entoa seu melancólico canto quando algum barco se aproxima. O

\footnotetext{
${ }^{39}$ Berta Waldman $(1992,52-3)$ é quem nos orienta na definição do narrador clariciano: "Na medida em que se identifica extremamente com as personagens, ele diz o que elas diriam, e o que elas dizem em discurso direto é o que o narrador poderia dizer. Com isso, o diapasão narrativo é dado pelo discurso "indireto livre", espaço de enunciação neutro, a meio caminho do 'eu' e do 'outro"”.
} 
barqueiro, totalmente hipnotizado pelo canto, naufraga nas rochas da ilha e se deixa devorar pelas ondas marinhas.

A referência a este mito, feita pelo Ulisses clariciano, se por um lado se entrecruza com o daquela mesma sereia cujo canto o lendário Ulisses herdou ao sair vitorioso de sua travessia - signo da sujeição do logos, como tivemos a oportunidade de verificar -, por outro, em nível fabular, em várias ocasiões se vincula à referência mítica heiniana para reconstruí-la a partir do signo da alteridade ulissiana, Penélope. Em outras palavras, desvincula-se do seu canto de sedução para primar o jogo de sedução do tramar, do des-enredar da escrita, da palavra, alteridade do silêncio suplantado.

Mas, como se realiza esta passagem da sedutora sereia subjugada para a da ardilosa "eterna esposa"? E como esta se mimetiza em meta-narrativa?

Tal como ocorre na Odisséia, a transformação de Ulisses em narrador através de um "rito iniciático" que coroa a sua trans-formação em herói, Loreley também terá que superar a sua odisséia mediada pela aprendizagem cujo "rito iniciático" é a metáfora mesma do ato de "se escrever".

mas nada se passara dizível em palavras escritas ou faladas, era bom aquele sistema que Ulisses inventara: o que não soubesse ou não pudesse dizer, escreveria e lhe daria o papel mudamente (15)

A con-formação inicial descritiva revela, por sua vez, o seu primitivismo ancestral ("rainha egípcia" e "mulher bíblica" são algumas das referências explícitas como já nos referimos) ao passo de uma linguagem de truncamento monológico. As referências ao mundo marinho e à comunhão da personagem com sua natureza se destacam na medida em que seu canto mítico se silencia para a instauração do diálogo, necessário entre o casal de amantes e para restaurar a construção do romance. 
Já no primeiro banho marinho, realizado em tom heróico às cinco da manhã, Loreley comunga qual Vênus em um "ritual" sensual diametralmente sagrado e pagão: “Avançando, ela abre as águas do mundo pelo meio. Já não precisa de coragem, agora já é antiga no ritual retomado que abandonara há milênios" (79, negritos nossos). O mar e a maresia transpõem a masculinidade tão demandada por seu corpo: "E era isso o que estava faltando: o mar por dentro como o líquido espesso de um homem"(80). Este mesmo corpo que tinha dificuldades em reconhecer sua "forte herança agrária vinda de longe em seu sangue" (42), a recuperará na figura de Ulisses "O que chamava terra já se tornara o sinônimo de Ulisses, tanto ela queria a terra de seus antepassados".

Mar mítico e sagrado. Em sua assimilação se vislumbra uma das facetas da aprendizagem no encontro com seu próprio desconhecido:

Sim, os peixes já estavam lá, amontoados, prateados, de escamas faiscantes, mas de corpo encurvado pela morte. Os pescadores continuavam a esvaziar na areia novas redes onde os peixes ainda se mexiam quase mortos. E deles vinha o forte cheiro sensual que o peixe cru tem. Lóri aspirou profundamente o cheiro quase ruim, quase ótimo. Só a própria pessoa podia exprimir a si própria o inexprimível cheiro do peixe cru - não em palavras: o único modo de exprimir era sentir de novo. E, pensou ela, e sentir a grande ânsia de viver mais profundamente que esse cheiro provocava nela. Quem sabe, divagou, ela vinha de uma linha de Loreleys para as quais o mar e os pescadores eram o cântico da vida e da morte. Só outra pessoa que tivesse experimentado, saberia o que ela sentia, pois de quase tudo o que importa não se sabe falar. (99)

Yudith Rosembaum (1999, 19-20) entreviu no procedimento dialético clariciano de constituição da subjetividade e construção narrativa uma representação literária do sadismo. Neste sentido, conforme a estudiosa, a pulsão de morte surge como um “movimento disruptivo que lança as personagens para um confronto com o mundo, denunciando em cada uma delas a ameaça da estagnação". Em vários momentos, 
entrevemos estes movimentos em $U A$, aqui associados ora às "mãos pensas" drummondianas, ora à necessidade de superar essa estaticidade. Tal superação, como denunciado pelos frontispícios de Augusto dos Anjos e Paul Claudel, ocorre dentro dos parâmetros estudados por Rosembaum.

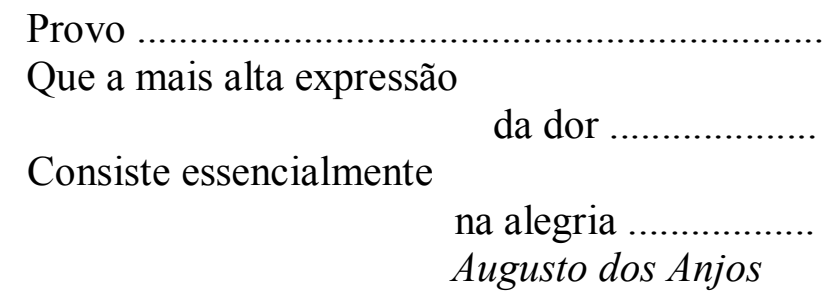

Jeanne:

Je ne veux pas mourir! J'ai peur!

Il y a la joie qui est la plus forte!

Paul Claudel

Assim pensada, a dianóia - ou dialética, conforme Rosembaum - do processo de construção do sujeito feminino e sua constituição na narrativa, se ocorre por meio da assimilação do sagrado para alcançar o terrenal - de aceitação de sua natureza para posterior superação -, também promove através da ironia, a perversidade. É com fina ironia que o narrador traça a posição que Loreley se delega ante "o grande Ulisses". Ora, durante a maior parte do romance seguimos o fluxo de consciência, o "pensar" de Lóri, quem declara diversas vezes "que pensar não lhe era natural"; enquanto a figura de Ulisses é diligentemente ocultada pelas ausências "necessárias" para que a narrativa se estruture nesta elipse ou, antes, nesta transposição. De fato, como propõe Rosenbaum $(1999,42)$, “é preciso pensar a questão do sujeito em Clarice à luz de uma concepção não mais vinculada ao cogito cartesiano". Afinal de contas, a ancestralidade da sujeição 
feminina se reflete aqui, sobretudo e ironicamente, na classe social representada por Loreley $^{40}$.

Terra ancestral e remota. É de suas origens agrárias, representadas pela figura dos cinco homens da família, que foge nossa heroína. Reencontrá-la, reencontrar-se e reconhecer-se, todavia, somente será possível na figura mítica, sagrada e profana, mise en abyme vertiginoso, que os substitui.

Lóri só tinha um medo: de que Ulisses, o grande Ulisses cuja cabeça ela segurava, a decepcionasse. Como seu pai que a sobrecarregara de contraditórios: ele a transformara ela, sua filha, em sua protetora. E ela, na infância, não pudera olhar sequer para o pai quando este tinha uma alegria, porque ele, o forte, o sábio, nas alegrias ficava inteiramente inocente e tão desarmado. Oh Deus, o pai se esquecia por uns momentos que era mortal. E obrigava ela, uma menina, a arcar com o peso da responsabilidade de saber que os nossos prazeres mais ingênuos e mais animais também morriam. nesses instantes em que ele esquecia que ia morrer, ele transformava menina em Pietà, a mãe dos homens. (145)

Mas os movimentos para esta transposição de papéis seguem o ritmo das descobertas, ou seja, o movimento de um adágio. E se faz do duo ao uníssono. "Nós é", diz Loreley ao final. Mas não sejamos prestíssimo: a odisséia demandada, do mythos ao logos, por várias vezes aparece metaforizada em quadros que passam por um processo de racionalização, como este:

Agora lúcida e calma, Lóri lembrou-se de que lera que os movimentos histéricos de um animal preso tinham como intenção libertar, por meio de um desses movimentos, a coisa ignorada que o estava prendendo - a ignorância do movimento único, exato e libertador era o que tornava um animal histérico: ele apelava para o descontrole - durante o sábio descontrole de Lóri ela tivera para si mesma agora as vantagens libertadores vindas de sua vida mais primitiva e animal: apelara histericamente para tantos sentimentos contraditórios e violentos que o sentimento libertador terminara desprendendo-a da rede, na sua ignorância animal ela não sabia sequer como,

\footnotetext{
40 A ironia da perversão clariciana se avulta ainda mais se tivermos presente a análise que Adorno e
} Horkheimer fazem da Odisséia. 
estava cansada do esforço de animal libertado. (15)

A passagem catártica pelo primitivismo e sua superação, ao suscitar a racionalização funcional da natureza de sua condição humana, revela o começo da compreensão e aprendizagem da sedução demandada pelo outro. O Eros filosófico, aqui evocado, prepondera a escrita ao canto. Neste sentido, a sonoridade do canto vai abrindo passo ao tramar silencioso. A sereia cede lugar à penelopeia ${ }^{41}$. Sugestivamente, este desabrochar se intitula "Luminiscência".

Mas a provação e o sacrifício se fazem necessários.

E houve a noite de terror. Ela ouvia passos indo e vindo. Olhou pela fresta da janela e viu que era o mesmo homem meio doido, com braços compridos de macaco, que durante o dia a seguira. Os passos vagarosos que vinham e iam e voltavam. Lóri sabia que ele esperava por ela. Pela fresta viu que ele fumava e pacientemente andava para cá e para lá.

Ela não suportou mais e telefonou para Ulisses. (33)

Como nos indica Pontieri (1999, 72-3) ao analisar A cidade sitiada, outro pólo dianóia em palavras de Nunes - a ser levado em consideração na obra de Clarice Lispector é o corpo e espírito. Nesta passagem de $U A$, como podemos notar, já seduzida por Ulisses, Loreley passa a mimetizar a imagem masculina como uma grotesca representação de seu estado de espírito e, junto a ela, constituem-se os avatares de sua alteridade. Bem sabemos que, desvencilhada do homem que a perseguira, Lóri se vale dos mesmos artifícios que usara instintivamente com este para conscientemente seduzir Ulisses. É o corpo que se evidencia aqui, enquanto o estado de espírito se revelara na imagem do homem seduzido:

\footnotetext{
${ }^{41}$ Segundo Adélia de Meneses $(1995,201)$ "Penélope: aquela que tece. Seu próprio nome (grego: Penelopéia) revela sua vocação 'pene', fio de tecelagem e, por extensão, trama, tecido (daí o nosso pano, do latim 'pannus'). E o substantivo grego 'penelope' significa dor. Tudo se explica quando pensamos que ela vivia na nostalgia $(=$ dor do retorno: 'nostos' $=$ volta, 'algia' $=$ dor $)$ de Ulisses, e que o pano que ela tecia (que tem a ver com a morte: era uma mortalha para Laertes, o pai de seu marido) era a garantia de sua fidelidade, como que vedava o acesso de sua sexualidade aos pretendentes que a assediavam. Fidelidade e sedução articuladas".
} 
- Lóri, está tudo bem. Foi um homem que você ficou olhando muito, possivelmente distraída, e ele com esperança acompanhou você esperando que você abrisse a porta.

- Venha até a porta.

Ele foi.

-Quer tomar um café? perguntou ela como pretexto para fazê-lo entrar.

Ele ficou no limiar. Ela estava de pé, em camisola curta e transparente. Ele ia dizer: "pode dormir descansada, eu dissuadi o homem a meu modo". Mas antes de dizer isso ele parou inteiramente, com os lábios apertados, e olhou-a de alto a baixo. Afinal disse:

- De dia telefono para você.

Com o desespero de fêmea desprezada, ouviu o carro dele se afastar. (33-4)

É também em seu "limiar", diante da indiferença de Ulisses, que Lóri conclui que seu canto sedutor lhe era intransponível. Teria que tramar um discurso silencioso que o tocasse, que irresistivelmente o enredasse. A arte de sedução, passa a ser trilhada, então, através da metis no uso da palavra e, esta arte, inclui também o saber usá-la em sua alteridade:

O que se passara no pensamento de Lóri naquela madrugada era tão indizível e intransponível como a voz de um ser humano. Só o silêncio da montanha lhe era equivalente. (35- negritos nossos)

E o que se segue, depois de uma madrugada em claro, é a decisão de escrever a Ulisses. Mas, sobre o quê? Sobre a ausência, sobre o silêncio que o vazio faz ouvir e origina a condição de sua existência ${ }^{42}$. Em outras palavras, "a alteridade que engendra o feminino é o homem" (ROSENBAUM: 1999, 58-9) e, sua figura, "por excelência, será a palavra, o discurso, o ato da linguagem", o que nos abre passo para o entendimento da estrutura deste romance.

Como bem se sabe, a figuração feminina da astúcia associa-se quase sempre à arte da tecelagem:

\footnotetext{
42 Tal como já tivemos a oportunidade de assinalar, em palavras de Lucia Helena Carvalho, Lucia Castello Branco e Ruth Silviano Brandão, no apartado 2.1.
} 
(...) Pandora (a primeira mulher), tecelã, que aprendeu a arte das fiandeiras com a deusa Atena, cujo epíteto é exatamente Atena Penitis, a "tecelã". Mas há também Ariadne, que desafia a deusa Atena a arte da tapeçaria e acaba transformada em aranha. E há as Parcas, que tecem a trama dos destinos humanos. Todas, mulheres. (MENESES: 1995, 200)

Por outro lado, o estatuto ambíguo, ou antes, a dianóia do feminino tanto na Odisséia como nas Mil e uma noites e no poema de Heine - ora acolhedor e traiçoeiro, ora atraente e perigoso - reserva certa afinidade com as imagens e o vocabulário relativo à arte de tecer: trama, teia, malha, rede, tramar, urdir, enredar, forjar. Esta combinação metafórica aproxima astúcia, trama e narrativa na figura da personagem feminina, manipulada por uma autora ${ }^{43}$.

Ao urdir os fios do tecido narrativo, o narrador trama e enreda, tal como faz a tecelã habilidosa em seu ofício. Ao recriar ou reescrever, através destas várias facetas, os vários mitos em seu ponto mesmo de contato, Clarice tece a rede do imaginário e da fabulação de onde nasce e toma forma a mimesis, para, neste mesmo sentido, em um movimento mise en abyme, subvertê-la na metáfora narrativa, em meta-narrativa.

\section{5 - A assombração do silêncio: "o núcleo último da pessoa"}

Benedito Nunes (1989: 13), explorando o inventário crítico que se formou a partir do primeiro romance de Clarice Lispector, não deixa de perceber os traços de Joyce e Woolf na narrativa clariciana; entretanto, pontua:

\footnotetext{
${ }^{43}$ Concomitante a redação de UA, Clarice escreve diariamente como colunista para o Jornal do Brasil (1967-73). É a partir da leitura dos textos publicados em sua coluna, coletados no volume A Descoberta do Mundo, que temos a clara noção de que vários de seus textos escritos em primeira pessoa $(E u=$ Clarice Lispector) são totalmente inseridos nas falas das personagens ou na narrativa onisciente de $U A$.

${ }^{44}$ Clarice Lispector, apud BORELLI: 1981, 14
} 
Ora, o que liga o romance de Clarice Lispector a esses autores é menos uma técnica ou um procedimento particular do que os processos comuns - o monólogo interior, a digressão, a fragmentação dos episódios -, que sintonizam com o modo de apreensão artística da realidade na ficção moderna, cujo centro mimético é a consciência individual enquanto corrente de estados ou de vivências.

Este centro mimético, como já tivemos a oportunidade de verificar, deflagra-se no "esgarçamento" da linguagem e se constitui como uma metáfora do fazer literário: com seus volteios poéticos agônicos, a narrativa de $U A$ dramatiza o universo do sujeito outro feminino no momento crítico de sua construção, ou seja, em plena crise ${ }^{45}$. Estes movimentos, de respiração da frase, necessariamente implicam na relativização do tempo, ou ainda, na visualização do fragmentário processo de assimilação do tempo para a constituição do sujeito e da narrativa.

O romance se abre em plena Primavera. Esta referência temporal, que se traduz também em experiência pictórica narrativa, é a porta de um ciclo sazonal que projeta as fases pelas quais texto e personagem perpassam. Entretanto, ao cumprir o percurso e voltar à Primavera o ciclo não se encerra, antes, tanto o romance, enquanto estrutura, como a personagem, em sua busca formativa, e o ciclo sazonal chegam ao seu clímax.

Mas, se por um lado, essa cronologia da fabulação narrativa é perfeitamente factual, obedecendo à configuração de um tempo cuja aparente e impecável linearidade mimética pode, pretensamente, nos dar a sensação de que a narrativa se constitui de um fluxo continuum, contribuindo, neste sentido, para sua percepção os movimentos disruptivos que abrem e encerram a narrativa; por outro, não deixa de se alimentar daquele que é o tempo outro, o não linear: o tempo lacunar da construção subjetiva e,

\footnotetext{
${ }^{45}$ Valemo-nos aqui da arguta ponderação de Rosenbaum $(1999,24)$ com relação a este aspecto da narrativa clariciana: "Devemos entender 'crise' aqui no sentido etimológico decorrente do verbo grego crino: 'escolher, distinguir, discernir, decidir, julgar [...]', sendo a crise (e daí, também a crítica) justamente o ato ou a faculdade de "peneirar' (crivo), separar e, portanto, julgar determinada situação." Rosenbaum, por sua vez, extrai suas referências de S.J. Isidro Pereira. Dicionário Grego-Português e Português-Grego. Porto, Livraria Apostolado da Imprensa, 1976, p. 333.
} 
portanto, da construção da narrativa contemporânea, cujo paradigma precursor, como assevera Nunes, é a obra de Joyce e Woolf.

Uma Aprendizagem, por sua vez, ao focalizar a angústia da experimentação do sujeito, a "experiência da memória, o ato de reviver o desaparecido (e, portanto, o descontínuo), de enfrentar a morte" (BRANCO: 1994, 28) e, sobretudo, o ritmo de dilatações, saltos e rupturas para a captação do porvir, aos poucos se transforma no "fluxo do instante". Se não bastasse, acrescenta-se a estas duas instâncias, o tempo mítico referido a cada uma das personagens.

Ao longo desse complexo temporal, que tem como base a captação de como personagem e narrativa chegam ao seu fluir vida-a-vida, podemos observar os pontos de contacto de sua compleição. Neste sentido, como não poderia deixar de ser, o tempo vivencial e o do enunciado não coincidem, antes se chocam até os limites de sua inextricável constituição. Uma mostra exemplar desse embate é o parágrafo que abre o capítulo que sucede o monólogo inicial:

Haviam-se passado momentos ou três mil anos? Momentos pelo relógio em que se divide o tempo, três mil anos pelo que Lóri sentiu quando com pesada angústia, toda vestida e pintada, chegou à janela. Era uma velha de quatro milênios. (22)

Os minutos se eternizam e a advertência se reflete na metáfora mesma da vacuidade que ecoa no cotidiano da personagem: "Enquanto isso era verão. Verão largo como pátio vazio nas férias da escola" (23). O tempo e a climatologia se misturam a seu estado de espírito: "Lóri não percebe que o tremor é seu, como não percebera que aquilo que se queimava não era o fim da tarde encaracolada, e sim o seu calor humano. Ela só percebe que agora alguma coisa vai mudar, que choverá ou cairá a noite.” (25). E o contrabalanço da pseudo-inatividade subjetiva é preconizado por uma narrativa, muitas vezes, lacônica ao mesmo tempo em que paradoxalmente precisa: "No dia seguinte 
tentou pacientemente de novo o crepúsculo. Estava à espera. Com os sentidos aguçados pelo mundo que a cercava como se entrasse nas terras desconhecidas de Vênus. Nada aconteceu." (30). Ao passo que, inicialmente, o tempo se aproxima e se choca com a instauração subjetiva, com a aprendizagem, ele vai se dissolvendo em referência pontual das profundas mudanças da personagem e da narrativa.

Com os complexos temporais em plena atividade narrativa, a inércia interior como vimos na referência às "mãos pensas" -, reflete o quão mais fácil é o apegar-se à comodidade de uma vida sem maiores arroubos, ao mesmo tempo em que denuncia na palidez melancólica das palavras a imagem construída e a ansiada: "sentou-se pra descansar e em breve fazia de conta que ela era uma mulher azul porque o crepúsculo mais tarde talvez fosse azul" (14), esta dissonância muitas vezes se consolida mais enfaticamente: "Não - não fazia vermelho. Era a união do dia com a sua hora mais crepuscular. Era quase noite e estava ainda claro. Se pelo menos fosse vermelho à vista como o era nela intrinsecamente. Mas era um calor de luz sem cor, e parada.” (22).

Nesta pugna entre ação e imobilidade - revelada pela disjunção temporal - para, enfim, optar pela primeira e empreender sua odisséia de descoberta interior, os minutos de flagelo lhe trazem a sensação de serem horas intermináveis (33) como no paradoxo de Zenão de Eléia; o limite entre passado e futuro parece se perpetuar no seu íntimo, devido à falta do que representa a sua trajetória agora iniciada: "E ela ansiava por ele porque exatamente ele lhe parecia ser o limite entre o passado e o que viesse" (41). Um passado repleto de viagens, cujos cenários sinistros ao mesmo tempo em que, momentaneamente obliteram a sua nova situação, obrigam-na a enxergar-se melhor:

Ela falara de Paris mas não da terra chamada Paris. Falara de como o inverno lá era cheio de trevas no crepúsculo e de como nevava neve ruim [...]. Contara por alto que um dia, ao escurecer, começara numa esquina a chorar de manso. Não havia ninguém por perto, e então ela começara a falar sozinha: "O Deus que me ajude nessas trevas geladas que são as minhas." (45 - negritos nossos) 
Como na estrutura do próprio romance - do monólogo ao diálogo, do mythos ao logos - Loreley terá que realizar um trabalho de sondagem íntima de seu passado para, somente após a sua superação, reestruturar dialogicamente seu presente. Esta não é uma tarefa fácil, o próprio Ulisses reconhece:

[...] pensei que poderia agir com você com o método de alguns artistas: concebendo e realizando ao mesmo tempo. É que de início pensei ter encontrado uma tela nua e branca, só faltando usar os pincéis. Depois é que descobri se a tela era nua era também enegrecida por fumaça densa, vinda de algum fogo ruim, e que não seria fácil limpá-la. Não, conceber e realizar é o grande privilégio de alguns. Mas mesmo assim não tenho desistido. Não, continuou ele falando como se ela não estivesse ali, não é mesmo com bons sentimentos que se faz literatura: a vida também não. Mas há algo que não é bom sentimento. É uma delicadeza de vida que inclusive exige a maior coragem para aceitá-la. (52 - negritos nossos)

Uma vez que Lóri deve passar por um processo de "purificação"46 ou "reencontro", o artifício narrativo, por sua vez, deve se pautar em imagens que recriam as suas ações. Esperar, urdir, seduzir são algumas das astúcias que, necessariamente, serão re-aprendidas e moldadas à demanda do logos literário.

Esperar. Enganam-se, inicialmente, Lóri e o leitor ao supor que o ato de esperar se equivale à estaticidade. Ainda que a personagem se enrede, a princípio, em uma expectativa promissora, sua latência logo se faz sentir: "A urgência é ainda imóvel mas já tem um tremor dentro.”(25) e, advertidos desde o início, sabemos que é Ulisses quem, em sua própria odisséia, a espera; portanto, se há alguma imobilidade, ela é ulissiana. Esta reversão de papéis implica, sobretudo, na mudança do referencial. Tratase, como sabemos, de uma bildung feminina.

\footnotetext{
${ }^{46} \mathrm{E}$ aqui, o mise en abyme proporcionado pelos seus vários encontros com o mar e os pescadores, nos oferece uma dimensão do processo de purificação.
} 
Urdir. A traição de Penélope é antológica. Sua devoção e fidelidade ao marido, a levam, num ardiloso jogo, a valer-se da tradição para usurpá-la. Para resistir aos pretendentes aqueus, o estratagema para ganhar tempo, curiosamente, é a falaciosa obrigação a que se submete de tecer uma mortalha para seu sogro, como se o seu desígnio para reencontrar-se com Ulisses fosse, pura e simplesmente, a fidelidade projetada em uma mortalha: a "garantia de sua fidelidade, como que vedava o acesso de sua sexualidade aos pretendentes que a assediavam. Fidelidade e sedução articuladas".(MENESES: 1995: 2001). Sua urdidura - ressalte-se, a sua "tramóia" pressupõe uma mortalha. A sua própria?

Seduzir. Ora, o Ulisses clariciano, ao passo que espera Loreley em sua trajetória de descobertas, não se exime, tal qual o Ulisses homérico, de seus furtivos encontros amorosos. Somente, à metade desse caminho (p. 96), passa a dedicar-se ao re-encontro com aquela que enreda e desenreda e que, com esta urdidura, se desvencilha da trama dos pretendentes que a perseguem, para enredar Ulisses em seus laços narrativos. Levando-se em consideração os despudores anteriores declarados ${ }^{47}$, a fidelidade de Loreley, ao longo da narrativa, é tão antológica quanto à de Penélope. Suas energias estão voltadas a dar outro significado a sua espera: de depositária da esperança à espectadora que assimila os atos, passos, gestos e palavras de sua alteridade em benefício próprio e, rapidamente, atuante e segura no uso da mesma metis ulissiana.

Nesta roupagem nova, o tempo, como já salientamos, projeta-nos em sua mimesis a estruturação da personagem e da narrativa. O complexo temporal, gerador da angústia do re-conhecimento e da construção subjetiva, cede lugar à percepção do tempo como o seu próprio fluir; o espaço interior vertiginosamente transborda ao exterior:

\footnotetext{
47 Sobre os (des)pudores de Penélope, remetemos ao estudo de Adélia Prado de Meneses(1995). Do poder da palavra: Ensaios de Literatura e Psicanálise, op. cit.
} 
Então estranhou-se a si própria e isso parecia levá-la a uma vertigem. É que ela própria, por estranhar-se, estava sendo. Mesmo arriscando que Ulisses não percebesse, disse-lhe bem baixo:

- Estou sendo... (71)

Mas, qual o caminho que a leva a alcançar este estado de serenidade que, em consonância com a forma narrativa, se dilatará em um continuum presente (no exemplo acima, no gerúndio do verbo)?

Ao observar Ulisses e seguir regiamente alguns de seus atos e lições, Lóri aprende que a escrita e o silencio e, logo, a escrita do silêncio e a essência silente das palavras, presentes nas orações a "o Deus" e na convivência cotidiana consigo mesma e com a sua alteridade são a demanda primordial para o avançar de sua jornada. Avançar, mas também retroceder. Curiosamente, o ato de tecer e destecer como metáfora correspondente à memória e ao esquecimento e, por extensão, à mimesis da atividade narrativa, revela-nos os movimentos que conjugam os contrários. O diurno e o noturno, a vida e a morte, a palavra e o silêncio, a união e a perda. Este jogo dialético, entretanto, somente se viabiliza na medida em que seus pressupostos vão se acomodando, ocupando o lugar e mudando o aspecto daquela "tela enegrecida". E nos quadros desta ocupação pulsa uma narrativa com traços gritantes de pintura contemporânea.

Berta Waldman, Ligia Chiappini, Olga de Sá e Regina Pontieri, entre outros estudiosos, já se detiveram no aspecto pictórico da obra clariciana assinalando, sobretudo, a importância que a plasticidade e, por extensão, a sua simbologia ocupam no âmbito de sua estrutura narrativa. A escritora mesma é quem admite: "Acho que o processo criador de um pintor e do escritor são da mesma fonte. [...] O texto deve se exprimir através de imagens e as imagens são feitas de luz, de cores, figuras, perspectivas, volumes, sensações" (apud BORELLI: 1981: 70). Lembremos, ainda, que 
Clarice também se aventurou pelo mundo das artes plásticas, dedicando-se, já no final da vida, a experiências com a pintura.

Sobre esta fase, há um instigante estudo de Lucia Helena Vianna Carvalho (2003) que, ao comparar a produção plástica clariciana com o diário da pintora mexicana Frida Kahlo, pontua que as obras de ambas se consagraram nacional e internacionalmente não só pelo mérito excepcional de ambas, mas também, pela marca exótica, ambígua, excêntrica e a singularidade da personalidade que ambas cultivaram e "pela capacidade que tiveram de serem elas próprias artífices da imagem que queriam perpetuar de si mesmas". Acentuando o fato de que ao se auto-referencializarem e teatralizarem a sua existência, inventando-se a si próprias como personagens, ambas criaram uma 'persona' de si, “conquistando um lugar não somente no mundo das artes e da cultura, mas na memória coletiva de sua gente".

Apesar de o objeto de análise a que nos propomos aqui ser diverso do tratado por Lucia Helena, o que nos chama a atenção em seu estudo é o fato de que podemos perceber que, como algumas de suas personagens, Clarice parecia cultivar uma máscara, ou ainda, querer perpetuar a imagem de uma 'persona' diversa, talvez, da sua verdadeira identidade. A estudiosa, centrando-se neste aspecto, se por um lado lança um olhar sobre Clarice Lispector como personagem, por outro nos chama a atenção para o aspecto expressionista de seus quadros, aspecto este também amplamente abordado por outros estudiosos na escrita anterior a esta fase.

Mas, o que notamos em $U A$ é a aventura por uma gama plástica um pouco mais ousada. Neste sentido, a "máscara", como elemento narrativo plástico e funcional que denota a forma como se estrutura o romance, mostra a teatralização da vida social representada pela personagem, ao passo que estabelece e revela as fases de sua superação num jogo de composição pictórica. 
Assim, se o primeiro ímpeto da personagem Loreley é o de querer permanecer com sua máscara, representada sob a imagem de uma personalidade difusa, aos poucos, vemos que esta imagem vai cedendo e diluindo-se em representações mais expressionistas a medida em que a personagem vai se desprendendo de sua 'persona'. Vejamos como, plasticamente, ocorre esta mudança.

A primeira imagem narrativa, que se nos apresenta tal qual a primeira fase de Picasso, é a do tom de uma melancolia extremada de mulher azul: "ela era uma mulher azul" (14); entretanto, na medida em que a expressão avança, sua aparência adquire a personificação dúbia de uma rainha egípcia e mulher bíblica (17). Esta representação exterior se choca com a interior, de vermelho intenso que, por sua vez, colide com a luminosidade que a circunda (22). Este quadro inicial, que poderíamos classificar como pós-impressionista, que vai se carregando de cores resplandecentes, fornece-nos mais que a amplitude da personagem, aproxima-nos do imaginário psicológico da narrativa através não só de uma descrição apurada, mas também da sinestesia que desperta em nós leitores.

Diametralmente a esse quadro, Lóri manipula a sua imagem, a sua máscara social. Ao escrever a Ulisses, projeta-se em uma imagem diferente, em total comunhão com seu interior:

"Existe um ser que mora dentro de mim como se fosse casa dele, e é. Trata-se de um cavalo preto e lustroso que apesar de inteiramente selvagem - pois nunca morou nunca em ninguém nem jamais lhe puseram rédeas nem sela - apesar de inteiramente selvagem tem por isso mesmo uma doçura primeira de quem não tem medo: come às vezes na minha mão. Seu focinho é úmido e fresco. Eu beijo o seu focinho. [...]."

Ela sorriu. Ulisses ia gostar, ia pensar que o cavalo era ela própria. Era? (28-9)

E a resposta à pergunta que fica no ar surge poucas páginas depois: “a fé pode ser um grande susto, pode significar cair no abismo" (32). Avançando neste abismo, 
vemo-nos diante de um grito tão expressionista e devastador como o de Munch. O quadro se monta em um mise en abyme vertiginoso, o grito da mulher rejeitada pelo homem que a abandonou em silêncio se faz representar através da palavra escrita que, por sua vez, pratica plasticamente imagens fatasmagais:

É tão vasta a noite na montanha. Tão despovoada. A noite espanhola tem o perfume e o eco duro do sapateado da dança, a italiana tem o mar cálido mesmo se ausente. Mas a noite de Berna tem o silêncio. (36- negritos nossos)

Mas, ao pintar com palavras o cenário de seus medos e mágoas, tantas vezes silenciados em seu íntimo, mais que aliviá-la e lhe servir de mecanismo de sedução, fazlhe perceber que já avançara em sua aprendizagem; tal mecanismo também nos alerta para o cenário que, verdadeiramente, compõe a sua essência.

Se Berna é a representação violenta do silêncio, o vazio desde o qual brotará a sua "condição de existência" e tudo "não era pensado: era vivido, com uma ou outra rápida passagem de luz de holofote na noite iluminando o céu por um átimo de segundo de pensamento e escuridão" (43), por um outro lado, Paris reflete que esta existência se compõe de "trevas geladas" (45).

Reconhecendo-se, Loreley - como vimos - deixa de se chocar com o tempo exterior e passa a tentar domá-lo em seu interior. Por outro lado, a assimilação do silêncio como demanda de sedução discursiva se transforma em comportamento que the auxilia nesta nova fase temporal: "Mas Lóri já o conhecia: este ar vinha de que ele tranqüilamente treinava instante por instante um modo de abrir caminho", portanto, em ato reflexo, Lóri "manteve-se em silêncio, deixando que ele bebesse em silêncio, sem olhá-lo"(58). O tempo do discurso, então, converte-se na representação de seu fluir "Estou sendo" -, e, muitas vezes, em plataforma de crises de angustiosa ansiedade. Esta 
envolvente comunhão se faz perceber na imagem subseqüente. A de seu reencontro com o mar.

Vai entrando. A água salgadíssima é de um frio que lhe arrepia e agride em ritual as pernas.

Mas uma alegria fatal - a alegria é uma fatalidade - já a tomou, embora nem lhe ocorra sorrir. Pelo contrário, está muito séria. $\mathrm{O}$ cheiro é de uma maresia tonteante que lhe desperta de seu mais adormecido sono secular. (79 - negritos nossos)

É como o nascimento de Vênus que Loreley ressurge: “espantada de pé, fertilizada" (79), "com as conchas das mãos cheias de água" (80). E, a partir desta experiência, não mais se reconhecerá em sua máscara de outrora:

É que, depois de anos de relativo sucesso com a máscara, de repente - ah menos que de repente, por causa de um olhar passageiro ou de uma palavra ouvida do chofer - de repente a máscara de guerra da vida crestava-se toda como lama seca, e os pedaços irregulares caíam no chão com um ruído oco. E eis rosto agora nu, maduro, sensível quando já não era mais para ser. E o rosto de máscara crestada chorava em silêncio para não morrer. (86)

E eis que, mesmo advertida por Ulisses do risco, Lóri decide ir com ele ao Posto 6. Ali, entre os peixes mortos, ela sente a sua essência vibrar e comungar com o que vê. A natureza morta resplandece vida:

Sim, os peixes já estavam lá, amontoados, prateados, de escamas faiscantes, mas de corpo encurvado pela morte. Os pescadores continuavam a esvaziar na areia novas redes onde os peixes ainda se mexiam quase mortos. E deles vinha o forte cheiro quase ruim, quase ótimo. Só a própria pessoa podia exprimir a si própria o inexprimível cheiro do peixe cru - não em palavras: o único modo de exprimir era sentir de novo. $E$, pensou ela, e sentir a grande ânsia de vida mais profundamente que esse cheiro provocava. [...] Aspirou de novo a morte viva e violentamente perfumada dos peixes azulados, mas a sensação foi mais forte do que pôde suportar e, ao mesmo tempo, que sentia uma extraordinariamente boa sensação de ir desmaiar de amor, sentiu, já por defesa, um esvaziamento de si própria: (99 - negritos nossos) 
E como com a chegada do inverno "Não havia aprendizagem de coisa nova: era só a redescoberta" (100), o ritual planejado, um almoço de comunhão do sangue e animal morto - galinha ao molho pardo ${ }^{48}$ - em plena Floresta da Tijuca, parece apenas acontecer. Todavia, notemos de que forma nossa personagem vai a este encontro: de suéter e saia vermelhos, esperara Ulisses enfrente a sua casa, antes do horário para que ele a visse com seu guarda-chuva vermelho que quando aberto "parecia um pássaro escarlate de asas transparentes abertas" (101). A estreita comunhão com o sangue pardo do pássaro morto, mais uma vez, dá-se diametralmente por meio de uma imagem vivaz - como apontamos acima -, num já reflexo do fluir de sua projeção. E é neste ritual que sua personagem interior começa, mudamente, a sofrer mudanças: "Tomava café e pensava sem palavras, meu Deus, e dizer que é noite plena e que eu estou plena da morte grossa que escorre com perfume de amêndoas doces".(108 - negritos nossos)

Mas se a origem da Primavera é a morte necessária em pleno dia ${ }^{49}$, Loreley a anela e, qual Penélope, trama a sua mortalha:

Ah como queria morrer. Nunca experimentara ainda morrer - que abertura de caminho ainda tinha à frente. Morrer teria a mesma pungência indizível do bom. A quem daria a sua morte? Que seria como os primeiros calores frescos de uma nova estação." (115)

Com esta experiência, torna-se tão mais confiante que toma atitudes sem levar em consideração o que Ulisses possa pensar e, numa visível ruptura, deixa de se ver

\footnotetext{
${ }^{48}$ Alie-se a esta cena, uma passagem anterior. Ulisses chama a atenção de Loreley para a voracidade humana de alimentar-se do sangue alheio: "é preciso ao esquecer a violência que temos" (98). As palavras de Ulisses e as de Loreley, presentes nesta passagem, são as mesmas utilizadas por Clarice, em primeira pessoa, numa crônica publicada no $J B$ em 13 de dezembro de 1969 e, posteriormente, coletadas em $A$ Descoberta do Mundo. São várias outras crônicas deste volume que nos chamam a atenção para o fato de remeterem diretamente à gênese do romance, talvez para o pressuposto de ser tanto Ulisses como Loreley uma espécie de alteridade clariciana.

${ }^{49}$ As duas imagens anteriormente vistas - o contato com os peixes mortos e a forma voraz com a qual Lóri comunga com o sangue da "galinha ao molho pardo" - dimensionam a formação subjetiva da personagem na dinâmica da estruturação narrativa. Enquanto esta bordeja os limites da experimentação plástica, aquela se vale desta para recriar as imagens sugeridas pela fabulação narrativa. Conforme vimos, as sereias se constituem ambiguamente como peixe-mulher ou pássaro-mulher. A "articulação" destes pressupostos estruturais plásticos e o resgate de sua simbologia, por sua vez, reitera o modus operandi clariciano de subversão da estrutura romanesca, como veremos mais adiante.
} 
como uma projeção da alteridade ulissiana para firmar-se como sujeito. Assim, ocorre uma mudança intrínseca desde o ponto de vista do objeto de análise. A narrativa deixa de apresentar a expectativa que Lóri pensa que Ulisses lhe tem, para centrar-se na que ela tem de si. Ulisses deixa de ser o preceptor, o modelo a ser admirado e seguido.

Esta mudança implica, em termos de estrutura, numa independência de perfeita sintonia temporal (116). É a partir de então que Loreley começa a treinar o seu autocontrole (119). E, como se "fosse um pintor que acabasse de ter saído de uma fase abstracionista, agora, sem ser figurativista, entrara num realismo novo" (123). E esta fase se aproxima, na sensualidade que dá ao conjunto das formas, a uma figuração poética cesarioverdiana. É nesta sensual introjeção de imagens exteriores, que vemos que aquela "tela negra" vista por Ulisses já cede lugar a uma outra, branca e iluminada. E então, tela nua, Lóri passa a buscar uma imagem para refletir:

Então ela se perguntou, como antes fazia, já que perdia tanto as coisas que guardava: se eu fosse eu e tivesse um documento importante para guardar que lugar eu escolheria? Na maioria das vezes isso a guiava a achar o perdido.

Mas desta vez ficou tão pressionada pela frase "se eu fosse eu" que a procura da prova se tornara secundária, e ela começava sem querer a pensar, o que nela era sentir.

[...] Lóri achava que se ela fosse ela, os conhecidos não a cumprimentariam na rua porque até a sua fisionamia teria mudado. "Se eu fosse eu" parecia representar o maior perigo de viver, parecia a entrada nova do desconhecido.

No entanto, Lóri tinha a intuição de que, passadas as primeiras pertubações da festa íntima que haveria, ela teria enfim a experiência do mundo. (125-6)

A Pietà, imagem do encontro amoroso ${ }^{50}$ projetada sob a ótica de Lóri, revela-nos um outro Ulisses - totalmente diferente daquele que ela vinha mtificando narrativamente -, mais humano e totalmente tangível a sua nova condição narrativa: "Por um instante,

\footnotetext{
${ }^{50}$ Para uma análise mais detida desta imagem, retememos à tese de doutorado Cenas de amor e morte na ficção brasileira (1990) de Lucia Helena de Oliveira Vianna Carvalho, brilhante trabalho cuja publicação em espanhol the rendeu o prêmio "Casa de las Américas" em 1996.
} 
como se tivesse combinado, ele beijou a sua mão, humanizando-se". E é com a leveza de quem já depurou suas sombras que Lóri se assemelha às etéreas pinturas de Chagall (p. 147).

Devido ao domínio do tempo, a morte, tão anelada e "necessária", "perdera a glória” (p. 153). O ensaio sem estilo, ansiado por Ulisses, é a forma que adquire o romance. A narrativa, ao seguir os passos de Loreley em sua aprendizagem, nada mais faz que usurpar os alicerces do gênero: “A meu ver você não pertence a nenhuma classe Ulisses. Se você soubesse como é excitante eu te imitar." (p. 153)

É com a autoridade de quem visitou as suas próprias profundezas e adquiriu o conhecimento necessário para suportar o silêncio da própria existência que Lóri está pronta para calar o discurso ulissiano, pois aprendera retoricamente que "Amor será dar de presente um ao outro a própria solidão? Pois é a coisa mais última que se pode dar de si, disse Ulisses." 
El sueño que lo había visitado era de amor. Un amor soñado. Un amor realizado en la plenitud del sueño. Dulcinea existió plenamente, mas sólo dentro del amor de don Quijote, al que no pudo jamás desmentir. Encontró así la identidad de la persona amada. Pero su trascendencia. Y para lograrla hubo de liberar a Dulcinea de la cárcel de ese su sueño, haciéndola visible para todos al modo de una "Beatriz", mediadora que a todos llega; haciéndola descender, sin mancharla, hasta el caído; alzándola hasta la visibilidad de la gloria. Liberó su sueño mismo llevándolo a la conciencia, donde se hizo voto, voluntad, finalidad que arrastra la persona. Y en este sentido, don Quijote se inventó a si mismo. Condujo su sueño en libertad entre la realidad. Pero como la realidad no lo albergaba, hubo de transformar la realidad del único modo que le era posible, soñándola. Su acción es libre, es un despertar. Y su sueño fue a dar a la realidad envolviéndola.

María Zambrano, El sueño creador

"La leyenda quiere explicar lo que no tiene explicación.

Como nacida de una verdad, tiene que volver a lo inexplicable".

Franz Kafka, Prometeo

- Ulisses, você se lembra de que uma vez me perguntou por que eu voluntariamente me afastara das pessoas? Agora posso falar. É que não quero ser platônica em relação a mim mesma. Sou profundamente derrotada pelo mundo em que vivo. Separei-me só por uns tempos por causa de minha derrota e por sentir que os outros também eram derrotados. Então fechei-me numa individualização que se eu não tomasse cuidado poderia se tornar em solidão histérica ou contemplativa.

Clarice Lispector, Uma aprendizagem 


\section{CAPÍTULO III}

\section{1 - A oltridade: do mythos à mimesis meta-ficcional}

Walter Benjamin, em “O Narrador”, texto de 1936, chama-nos a atenção para o fato de que:

el arte de la narración está tocando su fin. Es cada vez más raro encontrar a alguien capaz de narrar algo con probidad. ¿No se notó acaso que la gente volvía enmudecida del campo de batalla? En lugar de retornar más ricos de experiencias comunicables, volvían empobrecidos. Diríase que una facultad que nos pareciera inalienable, la más segura entre las seguras, nos está siendo retirada: la facultad de intercambiar experiencias. $(1991,112)$

Este anúncio do esgotamento das possibilidades narrativas, pautado na perda da faculdade de intercambiar experiências, entretanto, denuncia que a idéia do declínio do romance alardeado pelos estudos de Benjamin além de visivelmente apontar uma concepção de experimentalismo do gênero intimamente relacionada ao "fim" modernidade, flagra uma concepção do gênero romancesco, por vezes, rígida e estática.

Praticamente duas décadas depois, em 1954, Adorno volta sobre a concepção benjaminiana para rever entre alguns pressupostos, o posicionamento do narrador:

Basta perceber o quanto é impossível, para alguém que tenha participado da guerra, narrar essa experiência como antes uma pessoa costumava contar suas aventuras. A narrativa que se apresentasse como se o narrador fosse capaz de dominar esse tipo de experiência seria recebida, justamente, com impaciência e ceticismo. Noções como a de "sentar-se e ler um bom livro" são arcaicas. Isso não se deve meramente à falta de concentração dos leitores, mas sim à matéria comunicada e à sua forma. Pois contar algo significa ter algo especial a dizer, e justamente isso é impedido pelo mundo

\footnotetext{
${ }^{51}$ Ou seja, o fim de uma das etapas do processo de modernização.
} 
administrado, pela estandardização e pela mesmice. Antes de qualquer mensagem de conteúdo ideológico já é ideológica a própria pretensão do narrador, como se o curso do mundo ainda fosse essencialmente um processo de individuação, como se o indivíduo, com suas emoções e sentimentos, ainda fosse capaz de se aproximar da fatalidade, como se em seu íntimo ainda pudesse alcançar algo por si mesmo: a disseminada subliteratura biográfica é um produto da desagregação da própria forma do romance. $(2003,57)$

Portanto, as crises da modernidade, longe de propiciar o fim do romance, refletiram-se e promoveram inventivas renovações nas diversas estruturas dos gêneros literários. Talvez por esta razão, o grande estudioso frankfurtiano tomando como referência o Dom Quixote cervantino - aliás, a comprovação cabal de que o romance é o reflexo deste mundo em crise -, pondera que "Escribir una novela significa colocar lo inconmensurable en lo más alto al representar la vida humana. [...] la novela informa sobre la profunda carencia de consejo, del desconcierto del hombre viviente." (1991, 115) . Ponderações estas, também retomadas por Adorno:

O romance foi a forma literária específica da era burguesa. Em seu início encontra-se a experiência do mundo desencantado no Dom Quixote, e a capacidade de dominar artisticamente a mera existência continuou sendo o seu elemento. O realismo era-lhe imanente; até mesmo os romances que, devido ao assunto, eram considerados "fantásticos", tratavam de apresentar seu conteúdo de maneira a provocar a sugestão do real. No curso de um desenvolvimento que remonta ao século XIX, e que hoje se intensificou ao máximo, esse procedimento tornou-se questionável. Do ponto de vista do narrador, isso é uma decorrência do subjetivismo, que não tolera mais nenhuma matéria sem transformá-la, solapando assim o preceito épico da objetividade. $(2003,55)$

Se a narrativa moderna ${ }^{52}$ inaugura com um emblemático e dialético romance recriação mimética de um universo em crise que não somente rompe com a tradição ao

\footnotetext{
${ }^{52}$ Se por um lado estamos aqui retomando as concepções trabalhadas no capítulo anterior, a partir dos estudos de Carlos Fuentes, por outro, os termos modernismo, modernização e modernidade aqui referidos são empregados de acordo com as definições de Néstor García Canclini em seu artigo "La modernidad después de la posmodernidad" (in Modernidade: vanguardas artística na América Latina. São Paulo: Memorial / Unesp, 1990) a saber: a modernidade é uma etapa histórica, a modernização é o processo social que trata de ir constituindo a modernidade, e os modernismos, os projetos culturais que se relacionam com diversos momentos do desenvolvimento da modernidade e / ou capitalismo. Cabe aludir
} 
mesmo tempo em que a referencia, mas que também, valendo-se do recurso metanarrativo, fragmenta discursos e revela a cisão entre razão subjetiva e mundo desencantado - a sua perpetuação, como vimos no capítulo anterior, viabilizar-se-á pelo mesmo viés, o da atualização deste mesmo recurso dialético. Não é, portanto, despropositadamente, que Benjamin denuncia a sua descrença quanto à preservação inalienável da faculdade de intercambiar experiências, tal como ocorria na obra cervantina. Retomando as suas palavras, Adorno revê esta "descrença" como sinônimo da decadência do preceito épico da objetividade.

O tecido da experiência transmissível, cerne da narrativa épica de outrora, que pressupunha uma íntima relação entre vida e palavra, com o advento do romance moderno se desfaz como representação de uma realidade intrínseca à sua própria dimensão. Assim, figura do homem produzido pela modernidade revela, cada vez mais, um depauperamento da experiência suscetível de ser narrada. Na opinião de Benjamin $(1991,135-161)^{53}$, é a emblemática narrativa de Franz Kafka que, através de experimentos miméticos, ressalta uma forma peculiar de recriação narrativa cuja tensão imprime o choque entre a experiência tradicional e a vivência moderna e, desta forma, ao nosso ver, renova a operação mimética cervantina.

A experiência mimética kafkiana e a tensão por ela gerada, como por sua vez nos esclarece Marthe Robert (2006, 187-8), aplicam-se simultaneamente a vários modelos: mitos, contos de fadas, romance de aventuras, narrativas folhetinescas ${ }^{54}$. Não

que os estudos de García Cancline se baseiam nos de Marshal Berman (1986), os quais também levamos em consideração.

53 O ensaio "Franz Kafka" é de 1934, entretanto, conforme aponta Inácio Costa (2005), nele já podemos perceber as idéias que nortearão "O narrador", dois anos depois.

54 "La misma mezcla, con dosis variadas y a veces nuevos ingredientes, interviene en la composición del Proceso, que es una novela policíaca (cuyo enigma no es el criminal, sino su ausencia), al mismo tiempo que la exégesis de un documento jurídico o religioso (Exégesis de la Leyenda), cuyo contexto nos es desconocido. En todos los relatos cuyo héroe es un animal que habla (el caso del ratón en Josefina la Cantante, el heriré de Investigaciones de un Perro, etc.) se trata evidentemente de fábulas, pero $L a$ Metamorfosis es también un cuento (La Bella y la Bestia) y El Topo Gigante (El maestro de Escuela del Pueblo) tiende al mismo tiempo hacia el mito fabuloso y el reportaje científico. Epígono y Proteo, Kafka 
obstante, ao mesmo tempo em que estes modelos são fielmente reproduzidos, também são drasticamente distorcidos, o que provoca uma desestabilização narrativa, peculiaridade esta inerente à narrativa kafkiana.

Por esta razão, a obra de Kafka se parece a tudo ao mesmo tempo em que refuta a totalidade, uma vez que é na aparência que subjaz a ruptura. Neste sentido, Benjamin (1991, 161) caracteriza "La verdad sobre Sancho Panza" como "una anotación que no sólo por ser una interpretación resultó ser la más perfecta".

No referido texto, o escritor tcheco recria o ilustre cavaleiro cervantino como uma fabulação de Sancho Pança: don Quixote, um pobre demônio que atormenta Sancho, torna-se inofensivo depois de ler livros de cavalaria e, desta forma, concede-lhe um divertimento para toda a vida. Ao re-elaborar e ao mesmo tempo descaracterizar a base dialética quixotesca, o texto kafkiano se insere em uma emblemática tradição paródica, reforçando, tal qual o texto cervantino, o elemento de subversão: a imitação irônica e o seu deslocamento / distanciamento desconstrutivo. Além do aspecto irônico paródico, o aparente também se presta como elemento base para o chiste. Benjamin pontua que este elemento é de tal relevância na obra kafkiana que chega a constituir a chave para o seu entendimento $(1993,251)$.

Por outro lado, ao resgatar as "forças arcaicas" (BENJAMIN: 1987, 154) em Prometeo, El silencio de las sirenas e Poseidón, Kafka - tal qual Borges que, anos depois, explicitamente reconhece a influência kafkiana - recorre às peripécias do narrador cervantino para aproximar-se do sedutor encantamento das palavras de viejas crónicas (La Muralla China), sin olvidar las fábulas, apólogos y parábolas que son de alguna manera su primer modelo de escritura, ni los géneros recientes de los que toma prestadas sus glosas eruditas o su misterio degradado (el enigma policial). De ahí el carácter inimitable de su obra, que se parece a todo, y esto es precisamente lo que menos muestra: un viaje sin fin a través de los siglos y los libros" $(2006,188)$. 
Scherazade, nas suas noites com o rei Xariar, e do canto irresistível de Ulisses, no banquete do rei Alcínoo.

Como para o objeto de estudo desta tese é a desconstrução kafkiana do relato homérico que nos interessa, concentremo-nos em El silencio de las sirenas (título conferido ao texto pelo amigo e testamenteiro Max Brod); este relato, cabe salientar, não deixa de ser um modelo exemplar da operação mimética kafkiana: ao retomar um dos mitos fundadores de nossa civilização, Kafka o transforma em uma fabulação narrativa. Se, conforme Benjamin $(1991,141)$, neste relato kafkiano "Ulises está en ese umbral que separa al mito de la leyenda", para Kafka $(1983,1322)$, "La leyenda quiere explicar lo que no tiene explicación" e "Como nacida de una verdad, tiene que volver a lo inexplicable." Portanto, ao se referir ao Ulisses mítico, Kafka confere ao relato um fundo de "verdade" - entenda-se aqui como sinônimo da "experiência" benjaminiana - e é esta verdade, a do relato do Ulisses-aedo, que ele subverte. Neste sentido, o narrador kafkiano representa uma outra voz narrativa, a da experiência / vivência literária. O mito perde, assim, suas características para se transformar em uma lenda ou conto de fadas e, desta forma, o relato coloca abaixo a totalidade épica em favor da ruptura fragmentária, desde este ponto de vista, mimesis da sociedade abarcada.

É já no início do relato que a desconstrução irônica coloca em cheque a sobriedade do relato homérico. A tão afamada metis ulisiana se transforma em picardia infantil "Existen métodos insuficientes, casi pueriles, que también pueden servir para la salvación.”(1983, 1323 - negritos nossos).

O Ulisses kafkiano, não só se faz amarrar ao mastro como também tapa diferentemente do que ocorre na Odisséia - os próprios ouvidos com cera. A narrativa ironicamente assinala esta conduta: "Contento con sus pequeñas estratagemas, navegó en pos de las sirenas con inocente alegría" (1983, 1323 - negritos nossos). Com este 
gesto ineludível, o texto referido, em choque com o novo relato, perde-se ante a alteridade que este destaca em suas várias perspectivas.

Ulisses, o mítico "marido eterno", deixa de ser o herói viril, herdeiro do canto das sereias; o logos, portanto, não nasce sob o signo do sacrifício. O jogo de gêneros também não é casual. Se na Odisséia a experiência é transmitida diretamente pelo canto herdado, no relato kafkiano, por sua vez, ela é mediada pelo narrador: a astúcia do narrador kafkiano corresponderia em igual medida à ulissiana. Com efeito, a reciprocidade é verdadeira. Ulisses deixa sua função de herói e passa a ser visto como um astucioso narrador. Com relação à metis do narrador ulissiano, o relato atinge a ousada ironia de colocar em dúvida a sua "veracidade": "No sucedió en realidad, pero es probable que alguien se hubiera salvado alguna vez de sus cantos, aunque nunca de su silencio"(KAFKA: 1983, 1324 - negritos nossos).

Mas, se já no início o distanciamento do narrador confere ao relato um tom de análise crítica ao mito referido, aos poucos, a narrativa em si mesma ganha as formas de um conto, aproximando-se dialeticamente, também através do distanciamento, do narrador e de uma tradição de reminiscência oral: "La tradición añade un comentario" (KAFKA: 1983, 1324). Este jogo narrativo, portanto, reforça a idéia de que a "tradição" além de referendar o relatado, também contribuiria para esclarecer algum ponto obscuro; o que acontece, entretanto, é o contrário. À raíz deste jogo, subjaz a diegese do próprio conto de fadas, como nos esclarece Benjamin:

El cuento de hada nos da noticias de las más tempranas disposiciones tomadas por la humanidad para sacudir la opresión depositada sobre su pecho por el mito. En la figura del tonto, nos muestra cómo la humanidad se "hace la tonta" ante el mito; [...]; en la figura del sagaz nos muestra que las preguntas planteadas por el mito son simples, tanto como la pregunta de la Esfinge [...]. Hace ya mucho que los cuentos enseñaron a los hombres, y siguen haciéndolo hoy a los niños, que lo más aconsejable es oponerse a las fuerzas del mundo mítico con astucia e insolencia. (De esta manera el cuento 
polariza dialécticamente el valor en subcoraje, es decir, la astucia, y supercoraje, la insolencia.) El hechizo liberador de que dispone el cuento, no pone en juego a la naturaleza de un modo mítico, sino que insinúa su complicidad con el hombre liberado. El hombre maduro experimenta esta complicidad, sólo alguna que otra vez, en la felicidad; pero al niño se le aparece por vez primera en el cuento de hadas y lo hace feliz. (1991, 128-9 - negritos nossos)

Portanto, ao subverter a estrutura dos gêneros para discutir a cisão da mimesis existente entre palavra e experiência, dentro desse seu modo peculiar de estabelecer um diálogo literário entre as estruturas e a mimesis literária, Kafka não somente recupera o sentido de procrastinação contido na epopéia, mas, sobretudo, o faz para the conferir uma outra dimensão, a da reflexão mise en abyme da meta-narrativa, ou seja, da mimesis fragmentária contida na memória literária.

Desta forma, Kafka dissolve toda idéia de totalidade à qual pudesse corresponder a coerência de uma ordem narrativa, para dar lugar ao mundo fragmentado que sugere a idéia da inapreensível experiência subjetiva. (ROBERT: 2006, 188).

Mas e as sereias? Qual é o lugar destes monstros marinhos no relato kafkiano? Elas possuem duas "armas": o canto e o silêncio. Este último, inovação kafkiana neste relato, constitui-se como o centro transgressivo do mito. Muito mais poderosa que o canto, esta é a arma que as sereias usam, em vão, contra Ulisses em sua mítica passagem. A razão para que as contra-musas escolham esta implacável arma se divide em duas hipóteses: talvez o silêncio fosse a única arma capaz de aplacar o poderoso inimigo ou, ainda, seduzidas pelo aspecto de felicidade que estampava o rosto de Ulisses, elas tivessem se esquecido da canção.

Ora, não poderia haver ponderação mais contraditória. São guerreiras implacáveis ou deidades seduzidas? A ambigüidade que se instaura, requer, além da experiência, a metis do leitor para decifrá-la. 
O narrador - mimeticamente ulissiano - não termina seu relato antes de nos esclarecer que o fato de as sereias não terem acesso ao "foro íntimo" de Ulisses as salva da morte, pois se soubessem de sua "tramóia" pueril, teriam perecido.

Ulisses, com efeito, não herda na fabulação kafkiana o canto das sereias; ele, antes, usurpa de sua posição de "herói" astucioso para transmitir o intransmissível: o momento em que mais se aproxima das sereias é aquele no qual ele está mais distante, preso introspectivamente ao seu ato narcísico "las sirenas se esfumaron en su horizonte personal, y precisamente cuando se hallaba más próximo, ya no supo más acerca de ellas". Ulisses, assim, faz do silêncio das sereias o seu canto. E, o narrador, adverte "Ningún sentimiento terreno puede equipararse a la vanidad de haberlas vencido mediante las propias fuerzas."

A ruptura com a tradição, nos termos propostos por Benjamin, leva-nos a pensar que Ulisses não apenas teria representado a farsa para não perecer, mas também para que as sereias não sucumbissem. Ou, por um outro lado, já que a narrativa se prende ao mundo ulissiano, as sereias teriam também dissimulado sua falta de consciência - uma arma mais implacável ou deixar-se seduzir? - para que, talvez, seu canto não padecesse distorções em "voz" alheia e, assim, num devir, pudessem alcançar uma posição central para, enfim, propagá-lo.

A escolha do silêncio não é aleatória. Segundo a narrativa kafkiana Ulisses pereceria ao ouvir o canto que, certamente, transpassaria a cera; daí que as sereias sacrificam a sua voz / canto. Não é, portanto, a voz masculina que silencia a feminina, é ela que se silencia e, o que Ulisses propaga é uma pseudo-voz, ou antes, o que se propaga como canto é o silêncio, fica o “dito pelo não dito". Cabe-nos, então, o trabalho de resgatar os "verdadeiros" sentidos de canto e silêncio. 
A voz feminina, em boca masculina, está presente tanto no berço da narrativa literária como nas primeiras palavras e canções ouvidas e posteriormente reproduzidas pelo indivíduo. A voz que se ouve na mais tenra idade, mais que seduzir se faz necessária aprender como "arma" discursiva para a sobrevivência.

A presença desta voz feminina na literatura ocidental, por sua vez, parece perpetuar o silencio e o devir das sereias kafkianas. Dos gregos, temos como herança mais notícias de Safo que propriamente suas poesias. Entre os romanos, a voz feminina não passa de uma diáfana presença em alguns poetas líricos.

Neste sentido, é interessante notar que embora a Literatura Espanhola tenha, já em sua origem, uma expressiva polifonia feminina (BLANCO AGUINAGA et alii: 2000, 57), raros são os estudos que remetem a estas vozes como parte constitutiva da literatura nacional ${ }^{55}$; quando o fazem se concentram, por sua vez, no "eu lírico" da voz feminina ou, por outro lado, empenham-se em retratar algum "traço peculiar" desta literatura produzida pelas mulheres, como se estivesse a espera de uma decodificação que a conduzisse ao patamar da Literatura propriamente dita. Esta característica atravessa historicamente os estudos sobre a Literatura Espanhola:

El tiempo de recuperación y reconocimiento de la presencia de mujeres (algunas) creadoras en el espacio y en el tiempo de Al Andalus necesariamente tiene que sustentarse en las denominadas fuentes históricas. Hecha excepción de algunos arabistas que a principios de este siglo se acercaron al papel genérico de las mujeres de Al Andalus y también a la construcción, a veces lírica y siempre distorsionadas, que las orientalistas ofrecieron de las mujeres en el Islam, es sólo en estas últimas décadas cuando un no muy nutrido grupo de investigadoras (y algún que otro investigador) inician y encauzan un verdadero proyecto de identificación y recuperación de las mujeres en Al Andalus, tanto desde la perspectiva de las relaciones sociales como desde la singularidad de algunas figuras. (OBRA et RODRÍGUEZ DE AZA: 2000, 103-4)

\footnotetext{
${ }^{55}$ Tal exclusão se torna sintomática de uma forma geral tanto na crítica e na ensaística, como nos estudos sobre a Literatura Espanhola ao extremo de haver, às margens desta estrutura estabelecida, uma outra estrutura, em grande parte constituída por mulheres, empenhada em estudar a chamada Literatura Femenina. Claro indício de uma disputa / celeuma sexista da crítica literária que adquire força no final dos anos 80 .
} 
Por outro lado, como assinala Rosa Rossi (in DÍAZ DIOCARETZ et ZAVALA: 1999, 24), "en pocos casos como en el amor cortés aparece claramente que la "mujer" es fruto de una codificación masculina". Com efeito, se na Celestina já encontramos uma crítica aos valores propagados pelo amor cortês, Cervantes, por sua vez, também ironiza e avulta ainda mais esta crítica ao criar uma Dulcinéia cuja codificação masculina de ideal cavalheiresco choca-se com a sua realidade mimética. E o que dizer das demais personagens femininas cervantinas que se valem destas mesmas codificações como simulacros das convenções sociais para teatralizarem seu papel e, assim, roubarem a cena?

Mas, se poucas são as mulheres que produzem durante o século de ouro, os manuais, por sua vez, incorrem na mesma falta de referência ou na total omissão, como a praticada com as poetas de $\mathrm{Al}$ Andalus ${ }^{56}$. Esta questão, que percebemos como um problema de linha ideológica na concepção e historicidade praticada pelos manuais de literatura espanhola, adquire mais "legitimidade" com o passar do tempo. Já bem entrado o século XX, com a publicação do romance Nada, de Carmen Laforet, e com o prestigiado prêmio Nadal que esta obra recebe - e, a partir dela, outras tantas escritas por mulheres -, a narrativa espanhola amplia seu universo de escritoras e de novas tendências narrativas que coexistem paralelamente.

\footnotetext{
${ }^{56}$ Conforme Carmen Toledo $(2000,29)$ "Dejando aparte algunos ejemplos curiosos por insólitos de la aportación a la literatura de mujeres de épocas más que pretéritas como es el caso de (...) Teresa de Jesús o Sor Juana Inés de la Cruz, tenemos que pasar página hasta el siglo XIX para encontrarnos con apellidos ilustres, muchas veces camuflados bajo seudónimos que ocultan la condición femenina de quien escribía (...) Cecilia Böhl de Faber (Fernán Caballero), Gertrudis Gómez de Avellaneda o Emilia Pardo Bazán. Desgraciadamente más recordadas por sus vidas que por sus obras, por sus amoríos y desengaños que por sus novelas. Hasta nuestro siglo no van a aparecer figuras femeninas cuyo quehacer narrativo se sobreponga de una vez portadas de lo que hasta entonces se había tomando como un extraño fenómeno, el de la mujer novelista".
} 
Entretanto, a crítica, estagnada em seu tempo e idiossincrasia, opta por ler estas obras sob um olhar mais histórico que propriamente literário, enquadrando-as, muitas vezes, nas várias generaciones de autoras españolas ${ }^{57}$.

Entretanto, cabe salientar que, já no final do XIX, há uma tentativa perceptível de ruptura desta tendência nos estudos sobre o Quixote e na retomada da prática do romance meta-ficcional - El primo Manso, de Galdós, Niebla, de Unamuno -, numa feroz crítica ao romance realista e, por conseqüência, à crítica literária. Esta tendência inventiva, fruto da tradição do romance moderno e, principalmente, da narrativa espanhola, buscando renovar-se através de uma tradição perdida com o final do Barroco, revela-se como um mecanismo de reflexão irônico e subversivo que provoca o leitor que, por sua vez, transforma-se em um dos pilares ativos e críticos da mimesis. Reivindicando a imaginação criadora e sua celebração, a meta-ficção recupera a arte e o gosto de fabular.

Voltamos, então, aos parâmetros propostos por Benjamin. Ao saber-se ficção e instaurar-se como tal na tradição da verdade / experiência literária, a meta-ficção estremece as bases da realidade e de sua mimesis, "para sacudir la opresión depositada sobre su pecho por el mito".

Sob este embate entre mythos, logos e mimesis o romance El silencio de las sirenas, de Adelaida Garcia Morales, propõe-se, já na referência ao relato kafkiano, como uma subversão do mythos, para uma reescritura do logos, a partir de seu vínculo à tradição mimética da meta-ficção, cujas raízes cervantinas são inegáveis.

\footnotetext{
${ }^{57}$ Se Azorín havia instituído uma nova nomenclatura para as tendências literárias que surgiam, o "generacionismo" e ainda que duramente criticado constituiu-se como uma nova forma de "acondicionar" obras e autores, a crítica que se debruça sobre a literatura produzida por mulheres também se valerá desta mesma terminologia para referir-se ao âmbito autoral feminino.
} 


\section{2 - Uma literatura feminina? A obra de García Morales e a crítica}

Jean Canavaggio em sua Historia de la Literatura Española (1995, 321-3), ao referir-se à obra de algumas escritoras espanholas, entre elas Adelaida García Morales, e ao colocá-las sob o subtítulo "La Literatura de las Mujeres", pondera:

Sin pretender encerrar a las mujeres en un gueto, como se hace en algunas historias literarias, reagruparemos bajo un mismo epígrafe un conjunto de importantes producciones femeninas que deben su unidad a la opción por determinados temas. (321)

Com esta ponderação, como já advertimos, notamos que a literatura produzida por mulheres é estudada, como tal, pela sua particularidade / peculiaridade. Neste caso, Canavaggio se apressa em justificar a sua classificação em um grupo a parte, fazendo alusão à temática comum que a obra das escritoras apresenta ${ }^{58}$. Entretanto, quando verificamos quais seriam os temas que formam esta unidade, percebemos que, de uma forma geral, são amplos e que são similares aos abarcados por outros escritores (homens) como por exemplo "inquietudes de su tiempo", "novela de tesis", "estudio del ambiente social", "explotación del itinerario psicológico de la mujer" (1995, 322). Razão pela qual deduzimos que pelo fato de focalizarem um universo de personagens femininas e por serem escritas por mulheres, obras e, conseqüentemente, escritoras são relegadas, quando delas se ocupam os estudos, a um gueto ou a qualquer outro espaço

\footnotetext{
${ }^{58} \mathrm{O}$ estudioso, citando a obra de Cristina Fernández Cubas, adverte que a referida escritora "rechaza, sin duda con razón, que se le llame "feminista"'. Entretanto, ao resenhar uma de suas narrativas, não justifica tal posição. Notemos que, não obstante citar os romances Mi hermana Elba, Los altillos de Brumal, Canavaggio prefere resumir o enredo de El año de gracia, que trata da história de Robinsón, ou seja, uma personagem masculina. Cabe aqui acrescentar a este respeito as palavras de Geraldine C. Nichols $(1995,198)$ : "La narrativa de mujer en España padece de la misma binaria suerte que el sexo femenino en el discurso hegemónico: no es "narrativa", es "narrativa femenina", es lo no-normal, lo anormal. Se la ve en bloque; su diversidad y riqueza es invisible. Cualquiera que comprara, que leyera ¿quizás esto es mucho pedir?- un cuento de Ana Moix y una novela de Rosa Montero, o una narración de Adelaida García Morales, otra de Luisa Echenique y una tercera de Esther Tusquets, no podría en conciencia decir que se parecen. Y eso que todas las nombradas escriben en castellano [...] A pesar de la patente variedad de esta narrativa, mucha de la crítica la corta por el mismo patrón."
} 
reservadamente assinado à margem do canon estabelecido, como o próprio estudioso se apressa em afirmar ou corrigir-se ${ }^{59}$.

A “contradição" presente no estudo de Canavaggio se avulta ainda mais quando trata da obra de García Morales, mais especificamente, do romance El silencio de las sirenas:

En esta novela pasamos de la tentación incestuosa de la protagonista de El Sur, a la historia de una mujer solitaria y muda, que sólo mediante hipnotismo consigue expresarse. Está enamorada de un hombre que no aparece jamás, y esa pura ausencia hace que lo ame más todavía. Si su confidente trata de interponerse o acercarla a la realidad, irrumpe la tragedia, como le ocurre a Don Quijote, que muere reconociendo al fin su locura y el peso aplastante de la realidad: el personaje de García Morales irá a morir a lo alto de una montaña, escapando de un mundo que le da miedo. Este relato de prodigiosa densidad, escrito en un estilo amortiguado, murmurado al borde del mutismo y de la herida, logra la forma perfecta de la confidencia. $(1995,323)$

Da recepção de El Sur, cujo sucesso o estudioso relaciona linhas antes ao fato de ter sido adaptado ao cinema, à pequena resenha de El silencio de las sirenas, Canavaggio perturba o estudioso que se pergunta como um romance pode ser comparado ao Quixote, ter uma prodigiosa densidade e, ao mesmo tempo, estar incluído no rol da literatura de las mujeres devido à similaridade e unidade temática que suas obras aportam.

Algumas ponderações no sentido entender o des-vinculamento da prosa escrita por mulheres do canon estabelecido, que em parte norteiam nosso estudo, são as de Jorgi Gracia (2000, 208-244), em cuja análise da prosa narrativa espanhola - primeiro suplemento ao nono volume de Historia y Crítica de la Literatura Española dedicado a "Los nuevos nombres: 1975-2000" -, não apenas assinala a vocação dos romances dos últimos trinta anos para um relato mais individual que coletivo, como também pondera

${ }^{59}$ Como se sabe, pelos ensinamentos da Semântica Argumentativa e da Análise do Discurso, uma negação - que não seja em resposta a uma pergunta - tem implícita a afirmação da proposição que se nega (DUCROT, 1977; GUIMARÃES, 1987) 
que o canon estabelecido, desde o pós-guerra até a virada do milênio, é deveras instável $(2000,208)^{60}$. Sobre este aspecto, Elizabeth J. Ordóñez $(1995,172)$ acrescenta que os escritores da chamada "democracia espanhola" se encontram entre duas opções igualmente "repugnantes". Por um lado, a teoria, que embora cheia de boas intenções, mostra-se visivelmente cansada e vazia de sentido e, por outro lado, o mercenarismo do mercado cultural. Gracia, por sua vez, agrega-nos ponderações bastante significativas a este respeito:

En un balance general sobre los intereses del hispanismo contemporáneo se hace difícil negar la conveniencia de estudiar la obra de Esther Tusquets, Rosa Montero o Marina Mayoral (las tres cuentan con numerosos estudios académicos). Lo menos gratificante es comprobar que estos análisis se han hecho sin que todavía se haya estudiado con algún detenimiento la obra de un extraordinario escritor, Francisco Umbral, o apenas se haya abordado el poder de novelista de Juan Marsé. [...] Y mientras parece muy recomendable que sigan afinándose los estudios de caracterización de la literatura femenina española - nunca tan abundante como lo ha sido en estas últimas dos décadas -, nada debería impedir que un escritor extraordinariamente dotado para la invención de personajes femeninos, como Álvaro Pombo, mereciese la atención académica desde ese punto de vista (o desde cualquier otro). $(2000,209)$

O impasse que em primeira instância o mundo acadêmico e o canon estabelecido pela crítica apresentam, não obstante comportarem outras instâncias, reflete, sobretudo, a demanda de mudanças requeridas na ideologia expressa na escritura da história literária espanhola e da percepção desta Literatura - "propriamente dita", como diria Antônio Candido e como já referimos anteriormente - como uma estrutura que se

\footnotetext{
${ }^{60}$ Gracia nos remete a vários fatores que contribuem para a dinâmica e volatilidade do canon, apontando, de uma forma geral, as características tanto da prosa quanto da crítica estabelecida a partir dela. Cabe destacar que um fator comum entre ambas e que contribui para a instabilidade do canon é o jornalismo (por extensão, a publicidade) e as fronteiras porosas existentes entre a universidade e a sociedade. Com relação ao primeiro, a relação mercantil que adquire a cultura e, por extensão a literatura, entre os meios de comunicação, autores, editores e público, contribuem para que alguns profissionais do ramo se incluam no rol de escritores. No que se refere ao segundo, os estudantes e a sociedade, de uma forma geral, estabelecem um vínculo estreito com os escritores através de colóquios, conferências e conversas promovidas por alguma instituição financeira ou editora, o que também contribui para o direcionamento de estudos acadêmicos. Não é por acaso, portanto, que após tantos prêmios literários, os trabalhos acadêmicos se voltem para este universo a fim de explorá-lo.
} 
viabiliza pela vitalidade de sua heterogeneidade ou vertentes. No entanto, parece que esta mudança, ainda que possamos constatar a presença de novos ares, segue a passos lentos ${ }^{61}$.

Assim, ainda que alguns manuais citem a obra de escritoras espanholas inclusive García Morales -, estas citações se vinculam ou nos remetem a estudos compendiados inicialmente em volumes sobre a literatura femenina ou, num esforço crítico que a partir do final da década de noventa começa a ganhar fôlego, em volumes dedicados a resgatar a crítica do romance espanhol atual publicada em jornais e revistas, muitas vezes, de difícil acesso à crítica especializada ${ }^{62}$ e ao público em geral.

A obra de Adelaida García Morales - e de tantas outras escritoras - está, portanto, estreitamente vinculada ao que se convencionou chamar "literatura feminina". Ainda que estejamos de acordo com o fato de que é inegável que as teorias feministas (ZAVALA: 1991, 29) - que norteiam a maior parte dos estudos dos referidos compêndios - ajudaram em grande medida a desmitificar e desvelar os usos ideológicos de análises literárias tradicionais ${ }^{63}$ - conforme vimos no estudo de Lucia Helena no capítulo anterior - e que é ineludível sua contribuição para a reescritura da crítica e mudanças epistêmicas, não compactuamos com a configuração estrutural e, principalmente, ideológica do canon da Literatura Espanhola estabelecido pela crítica histórica - presente principalmente nos manuais de história literária espanhola -, de colocar à margem a produção literária de autoras, conformando-lhes, através de um jargão de cunho expressivamente depreciativo, num lugar menor. Entretanto, por uma

\footnotetext{
${ }^{61}$ Para aprofundar no aspecto histórico do assunto, remetemos ao já citado artigo de Geraldine C. Nichols. A obra Desde la ventana, de Martín Gaite, também discute o assunto, mas o faz desde a perspectiva de sua experiência pessoal.

${ }_{62}$ Alguns exemplos de compêndios que descartam a questão do gênero são: Del Franquismo a la postmodernidad, de José B. Moleón; La nieve en el espejo: crónicas literarias, 1989-1995, de Juan Manuel González; El arte de la memoria: incursiones en la narrativa española contemporánea, de Inge Beisel.

${ }^{63}$ Faz-se necessário citar também outros estudos, ainda que não façam parte do rol das teorias feministas mas que contribuiram imensamente para entender as formas discursivas de poder, como é o caso de Foucault, Bataille, Lévi Straus, Bakhtin e Barthes.
} 
quase absoluta carência de outro material crítico, muitas vezes a ela teremos que nos reportar $^{64}$, sem, deixemos claro, visar contribuir para a manutenção de tal configuração ideológica.

Em 1981, com o lançamento de El Sur, García Morales inicia a sua trajetória literária $^{65}$. Esta primeira publicação, escrita concomitantemente ao romance El silencio de las sirenas, já apresenta características estruturais que se reiteram na diegese da obra da autora.

Narrada em primeira pessoa, esta novela ${ }^{66}$ chama a atenção da crítica em seu caráter temático - "complexo de Electra" - e clima de mistério - a morte do pai. Mas, esta narrativa de García Morales, com um olhar mais atento, permite-nos ir muito mais além do que nos sugere esta primeira interpretação.

Mañana, en cuanto amanezca, iré a visitar tu tumba, papá. Me han dicho que la hierba crece salvaje entre sus grietas y que jamás lucen flores frescas sobre ella. Nadie te visita. Mamá se marchó a su tierra y tú no tenías amigos. Decían que eras tan raro... $(1995,5)$

\footnotetext{
${ }^{64}$ Cabe aqui um esclarecimento em tom de advertência. Ainda que pouco estudada no Brasil, a obra de García Morales chamou a atenção da crítica devido à tradução ao português de El Sur e El silencio de las sirenas. Algumas resenhas foram publicadas no Brasil e Portugal, resenhas estas que se afastam do jargão da literatura feminina e que aproximam a obra da escritora a uma tradição literária espanhola.

${ }^{65}$ Ainda que começara a escrever El silencio de las sirenas em 1979, escreve e publica El Sur e Archipiélago em 1981, com esta última ganha o Premio Sésamo. Em 1983, sua obra se torna mais conhecida do público, devido à adaptação de El Sur para o cinema. Sua novela seguinte Bene, obra complementária de El Sur, é publicada junto a esta em 1985: El Sur seguido de Bene. Neste mesmo ano finaliza e publica El silencio de las sirenas, volume com o qual obtém os prêmios Herralde e Ícaro de romance. Outras obras: La lógica del vampiro (1990 - romance), Las mujeres de Héctor (1994 romance), La tía Águeda (1995 - romance), Nasmiya (1996 - romance), Mujeres solas (1996 - poesia), La señorita Medina ((1997 - romance), El accidente (1997 - conto), El secreto de Elisa (1999 romance), Una historia perversa (2001 - romance). El testamento de Regina (2001 - romance).

${ }^{66}$ Embora algumas críticas - como a de Heloisa Costa Milton - classifiquem El Sur como uma "novela curta" e "conto" - como é o caso da crítica de Linda Santos Costa -, decidimos optar pelas ponderações feitas por Massaud Moisés em seu Dicionário de Termos Literários.
} 
Adriana, a personagem narradora, já no primeiro parágrafo, situa-nos entre o futuro, o passado e o presente. A narrativa, portanto, construir-se-á sobre este tripé cambaleante $^{67}$.

Neste sentido, o relato se inclui em uma tradição romancesca de reminiscência trágica, aspecto este fortalecido pelo jogo espaço-temporal e pelo tema abordado. Passado, presente e futuro são os avatares - tripé esfíngico trágico - que regem um monólogo dirigido ao pai morto. Um único dia, como na tragédia, é o que basta para que se relate o destino oracular. A cisão com a linearidade espaço-temporal ${ }^{68}$, por outro lado, instaura-se como abismo estruturador de esferas lábeis.

Os pontos de contato com a tragédia se estreitam, ainda mais, em outro aspecto temporal: o ritmo. A medida em que a narrativa avança, podemos perceber uma musicalidade de tom fúnebre. O pai resolve enterrar o sul no norte e, por extensão, a sua vida e a de sua família, que viverá sob a sombra de sua personalidade sombria e intempestiva. Ao pé do túmulo, referido do primeiro parágrafo, o coro trágico vai tomando o tom de um réquiem. Adriana parece cantar a imagem do pai como um ato expiatório, para elevá-la, de uma vida condenada por todos ao esquecimento, à qualidade de uma experiência memorável através da construção de sua bildung. Este resgate, por sua vez, também se viabiliza através de outra voz não menos trágica, a poética.

\footnotetext{
${ }^{67}$ É interessante e elucidador aludir a palavras da autora sobre este aspecto do conto: "Creo que el tiempo tiene un lado de destrucción. Es decir, que lo que hay hacia el futuro es más bien muerte, pero también el tiempo tiene este lado de aprendizaje, de adquirir una experiencia, pero no sé porqué (sic) yo veo que es más tremendo lo que tiene de negativo, porque te acerca a la muerte y la destrucción." ( INSULA: 1985: 4)

${ }^{68}$ De tradição quixotesca e que se reflete, como vimos, de forma peculiar na narrativa kafkiana. O exemplo mais referido pela crítica, entretanto, é o romance inglês Tristan Shandy, de Lawrence Stern. Na literatura latino-americana, por outro lado, temos: Memórias póstumas de Brás Cubas, de Machado de Assis; La Guerra del Tiempo, de Alejo Carpentier e Terra Nostra, de Carlos Fuentes.
} 
A citação do verso de Friedrich Hölderlin ${ }^{69}$, “Qué podemos amar que no sea una sombra?", logo abaixo do título da novela - incorporando-se, desta forma, como parte da narrativa -, envolve com seu tom fantasmagal o relato e nos revela, de antemão, a dúvida que permeará, como ponto de equilíbrio de opostos, a narrativa: talvez o amor, que representa vida, não está vinculado a um corpo sólido e papável, mas a uma projeção diáfana e mutante, a um espectro do ser.

Adriana, seguindo os passos de Hölderlin também nos situará dialeticamente em seu limiar, entre esferas lábeis de difícil equilíbrio: a visão que temos de seu pai, não passa de uma projeção sua e vice-versa; a plataforma narrativa que objeta um futuro tem como direção o passado, refletindo um visível conflito do sujeito de localização e de instauração do presente; o masculino engendra o feminino, Adriana é uma imagem que se delineia a partir da forte presença paterna e vice-versa; a figura da mãe, representação do norte, da religiosidade e da racionalidade em oposição com a do pai, representação do sul, do misticismo (pêndulo) e da afetividade são as duas forças que con-fundem Adriana e a narrativa; a morte do pai, num pungente e egoísta ato suicida, é a presença mítica, fantasmagal e misteriosa que dá vida ao relato.

A ambigüidade da figura paterna, gerada pela protagonista e narradora, caminha sobre um abismo que representa toda a complexidade de sua formação, de sua individuação. Esta odisséia, com efeito, transforma-se em construção narrativa e formação da personagem - bildungsroman - e ambas se efetivam por meio do dialogismo e do dialético jogo de contrários que não fazem senão refletir metáforas narrativa e discursiva. Adriana, como o pai, não passa de uma sombra, um espectro: "Estaba solo sintiéndome lejos de todo. Y de pronto. Y de pronto apareció Adriana

\footnotetext{
${ }^{69}$ García Morales parece ter uma certa predileção pela obra deste poeta alemão, haja vista a referência explícita que seu romance Archipiélago (1981) faz à poesia homônima de Hölderlin.
} 
detrás de mí. [...] Creo que si los fantasmas existieran, aparecerían de la misma forma que ella".

A narrativa moderna também reflete, muitas vezes em espelhos convexos, as sombras e os espectros que ainda povoam as suas formas miméticas. Assim, não é casual que a formação e projeção de Adriana à sombra do pai se assemelhe a de uma das personagens mais emblemáticas da tragédia grega. Conforme nos esclarece Ricardo Krauel:

Electra nos sitúa ante una celebración de una feminidad “independiente", pero desde una exaltación de la masculinidad a la que aquélla habría de aparecer dialécticamente opuesta. Tal vez esa circunstancia pudiera revelarse como indicio de una autoría masculina (suponiendo que no supiéramos quién escribió el texto) o, en todo caso, como signo que denota la conformación del texto como monumento de una cultura institucionalmente masculina o patriarcal. $(1999,208)$

Em outras palavras, o mesmo se poderia ponderar com relação à Adriana. Mas o que nos inquieta neste relato são outras questões da tragédia clássica assimiladas pela narrativa moderna e presentes na narrativa de García Morales.

Como o espectador da tragédia, o leitor desta novela perseguirá com olhos ávidos o fim do relato em busca dos significados simbólicos, ou ainda, dos fatos apenas sugeridos no parágrafo inicial: o como e o porquê da morte do pai. Portanto, o "resgate do passado é a condição necessária para passar a limpo o presente, a possibilidade de uma viagem mítica de restauração da própria identidade” (MILTON: 1988, 29). Através do delinear de sua alteridade, num monólogo murmurante à beira de seu próprio abismo, numa inquietante busca por desvendar os mistérios propostos pela narrativa é que conseguiremos delinear a sombra da própria Adriana. Mistério. É este o recurso que a narrativa de García Morales transpõe à catarse trágica. É este um dos vieses pelo qual a narrativa ata o leitor. 
Nos significados e valores que o sul (Sevilha) adquire como passado do pai - na descrição de sua casa paterna com seu pátio sevilhano e do amor pungente que havia tido com Gloria Valle e não havia conseguido superar - e como presente de Adriana - no encontro com o irmão e na transposição deste ao lugar do pai, no mesmo espaço onde havia florescido e se concretizado o amor por Gloria Valle - percebemos uma leve ressonância do poema "Retrato", de Antonio Machado, no que tange à memória e à mimesis. Adriana nos conta a sua história ao sabor da história paterna, num jogo de leitura, representação e simulação de sua própria narrativa, numa astuciosa inversão de papéis:

Mi infancia son recuerdos de un patio de Sevilla, y un huerto claro donde madura el limonero; mi juventud, veinte años en tierra de Castilla; mi historia, algunos casos que recordar no quiero.

Ni un seductor Mañara, ni un Bradomín he sido - ya conocéis mi torpe aliño indumentario -, mas recibí la flecha que me asignó Cupido, dios del amor y amé cuanto ellas puedan tener de hospitalario.

Hay en mis venas gotas de sangre jacobina, pero mi verso brota de manantial sereno; $\mathrm{y}$, más que un hombre al uso que sabe su doctrina, soy, en el buen sentido de la palabra, bueno.

Adoro la hermosura, y en la moderna estética Corté las viejas rosas del huerto de Ronsard; Mas no amo los afeites de la actual cosmética, ni soy un ave de esas del nuevo gay-trinar.

Desdeño las romanzas de los tenores huecos y el coro de los grillos que cantan a la luna. A distinguir me paro las voces de los ecos, y escucho solamente, entre las voces, una.

¿Soy clásico o romántico? No sé. Dejar quisiera mi verso, como deja el capitán su espada: famosa por la mano viril que la blandiera, no por el docto oficio del forjador preciada. 
Converso con el hombre que siempre va conmigo

- quien habla solo espera hablar a Dios un día-;

mi soliloquio es plática con ese buen amigo

que me enseñó el secreto de la filantropía.

Y al cabo, nada os debo; debéisme cuanto he escrito.

A mi trabajo acudo, con mi dinero pago

el traje que me cubre y la mansión que habito,

el pan que me alimenta y el lecho en donde yago.

Y cuando llegue el día del último vïaje,

y esté al partir la nave que nunca ha de tornar,

me encontraréis a bordo ligero de equipaje,

casi desnudo, como los hijos de la mar.

Nesta primeira narrativa de García Morales, com efeito, já se faz notar uma característica estrutural peculiar e maquiavélica de seus narradores: a posse do discurso, seja ele oral ou escrito, e da história do outro para a construção de sua própria narrativa e identidade. Por um outro lado, é este o obscuro jogo dialético que enche a narrativa de mistério provocativo: o passado distante, cuja representação é o norte como sinônimo do passado de Adriana com a figura paterna que, paradoxalmente, somente adquire um significado resgatado no sul; o passado recente, a tentativa de Adriana transpor a história paterna - pela leitura e pela relação com o irmão -, na sua própria passagem pelo sul.

Talvez seja este tom de mistério provocativo que faça com que alguns críticos se abstenham em reconhecer a filiação clássica da narrativa de Garcia Morales, em termos também estruturais, e a comparem, devido ao tom confessional, à narrativa romântica ao mesmo tempo em que a aproximam à prática narrativa de Edgard Allan Poe (COELHO: 1987, 39) e Henry James (COSTA: 1989, 15).

Como podemos notar, a estrutura de El Sur compreende uma gama de possíveis filiações referenciais que vai, muitas vezes, ao sabor do repertório de quem a lê, em outras palavras, muitas vezes, aquém do dialogismo que a narrativa em si pode suscitar. 
Mais que simplesmente apresentar uma temática feminina ou sondar o universo feminino desde o "complexo de Electra", entretanto, percebemos que esta novela mantém uma profunda relação dialógica com a tradição romancesca e suscita uma inquietante pergunta: seria a narrativa atual uma mera sombra de seu passado?

A mesma indagação se faz presente em El silencio de las sirenas, romance que também mantém um paralelo entre a escritura e a sua desconstrução. Este complexo mecanismo, perfeitamente viabilizado na narrativa de García Morales, leva-nos a ver e a ler a sua obra como representativa dentro dos parâmetros de "experiência" benjaminiano e, portanto, dentro da tradição da narrativa moderna espanhola.

\section{3 - Uma narrativa que se faz narrativas}

"Dios permite que lo que no existe sea intensamente iluminado" com esta epígrafe de Fernando Pessoa, o romance El silencio de las sirenas ${ }^{70}$, a exemplo de El Sur, lança-nos num território povoado de sombras, cuja densidade narrativa e, sobretudo, a extraordinária riqueza polifônica fazem povoar o imaginário do leitor.

Escrita em primeira pessoa, a narrativa parece ser, inicialmente, um simples romance policial, uma vez que a ação descrita nos dois primeiros parágrafos se detém no detalhamento de possíveis "pistas" que impulsionam o ambiente misterioso:

Elsa se despidió de mí con una breve carta: "María, te dejo estos regalos, consérvalos si quieres. ¿Volveremos a encontrarnos? Un beso". Y se olvidó de firmar.

Sobre una mesita de madera, cubierta con un paño de terciopelo ocre, había ordenado diferentes objetos: una postal que reproducía un cuadro de Paolo Ucello: san Jorge y el dragón; una flor seca y azul que, según decía, se llamaba "Love in a mist"; una vieja caja china conteniendo una fotografía suya y la copia de todas las cartas que había enviado a Agustín Valdés; una carta que había recibido de

\footnotetext{
${ }^{70}$ As referências a esta obra se farão a partir da edição Barcelona: Anagrama, 1993.
} 
él, un retrato de Goethe contemplando la silueta recortada de un rostro de mujer; una sortija de platino con incrustaciones de diamantes; un libro: Las afinidades electivas; la reproducción de una litografía de Goya, en la que se ve a un hombre sobre una mujer que oculta su rostro con un antifaz. Al pie hay unas palabras: "Nadie se conoce". También me dejó un cuaderno, el suyo, en el que había ido escribiendo su amor, dirigido a Agustín Valdés. Y finalmente, había una carta para Agustín y que aún no había cerrado. (pp. 13-4)

A simplicidade, entretanto, dissolve-se na medida em que seguimos estas pistas, constituídas, em grande parte, por obras cuja estrutura narrativa servirá como um mecanismo de subversão do cânon que aportam. Busquemos, então, decifrá-las.

Como em El Sur, a narrativa começa pelo presente para, através de vestígios do passado (pistas), estabelecer um elo entre estes dois espaços temporais. A memória da narradora, as suas anotações e as cartas deixadas por sua amiga Elsa são também recursos estruturadores da narrativa e, como vimos, também utilizados naquela novela. A inovação está em como a autora trabalha estes elementos.

Biruté Ciplijauskaité (1988, 167-173) estabelece, como base estrutural de El silencio a presença de uma tradição narrativa semelhante às cartas amorosas. Em especial, às Cartas portuguesas. Segundo a estudiosa, o caderno-diário de Elsa (caracteristicamente epistolar), "escrito en soledad, en el que se dirige al amado ideal" (IDEM, 167) e as cópias de suas cartas, também enviadas a Agustín Valdés, caracterizam-se por uma escrita que se apóia num breve encontro no passado que assume, des-propositadamente, as proporções de uma relação amorosa, o que leva a mulher apaixonada à beira da loucura. A estudiosa se detém em comparar estar características entre a obra de García Morales e as de Mariana Alcoforado e de Mademoiselle de Lespinasse.

Seguindo este parâmetro, alguns aspectos no estudo de Ciplijauskaité adquirem certa relevância. O fato de o amor ser mais importante que o amado e que a vida: "Todo 
ello se engarzaba en el hilo de un sentimiento que quizá no fuera sino amor al Amor” (50), "Y creo que he muerto ya a todo menos a esta esperanza de amor. Si no es posible este amor, Agustín, no podré vivir.”(131). A paixão amorosa serve como força desencadeadora da criação literária, percebida por Agustín: "no me siento destinatario de sus carta" (141), "ese amor suyo, o lo que sea, como tú dices, me parece tan productivo...”(142). A partir destes pressupostos, a estudiosa compara o amor de Elsa com o que apresenta Kiekegaard em La repetición: um amor imaginário que se faz representar e realizar em um auto-diálogo, justificando a epígrafe de Fernando Pessoa. Estes aspectos desencadeiam a seguinte suposição: "Se podría decir que la novela no sólo es una historia de amor, sino también una meditación sobre la creación literaria" (IDEM, 169). Aspecto este que retomaremos mais tarde.

Embora a estudiosa assinale o processo narrativo como "re-transcrição" de um manuscrito, ela apenas o analisa a partir da ação de Maria, a narradora, de transcrever as sessões de hipnose e de definir minuciosamente o seu procedimento. Percebemos, por outro lado, que este procedimento de "re-escritura" é muito mais complexo: pode ser dividido em camadas e se impulsiona a partir deste primeiro movimento de re-datar decifrar as sessões de hipnose.

Neste sentido a narradora, como vimos com relação a El Sur, apropria-se do discurso alheio para constituir o seu próprio discurso, para preencher o vazio / silêncio de sua própria experiência:

Su repentina decisión me dejó desconcertada. La noche anterior, cuando me confirmó su marcha, sentí un silencio nuevo, más intenso, realmente perturbador. Pensé en mi vida, en el vacío que ella me dejaría con su ausencia. (162)

O ponto de partida seria, com efeito, os relatos transcritos a partir das sessões de hipnose. Este relato e sua meta-narração, por sua vez, proporcionam a inclusão de outras formas discursivas: o diário de Elsa, as cópias das cartas que esta escreve a Agustín, 
uma única carta de Agustín a Elsa, a transcrição das conversas com Elsa e Matilde e, por fim, da conversa telefônica da narradora com Agustín. A narrativa, portanto, pende mais para a palavra escrita, em termos estruturais, que para a oral.

Entretanto, a oralidade tem um papel extremamente importante, como bem assinala a estudiosa lituana $(1988,170)$. É com as palavras que Elsa constrói o imaginário da narradora e a seduz, em primeira instância, como ouvinte / leitora. E o faz, principalmente, através de palavras vocalizadas durante as sessões de hipnose: "Pues eran precisamente las palabras el único material mundano con el que iba construyendo su singular historia" (57). Por outro lado, a palavra escrita cobra sua devida importância no diário deixado por Elsa que, com efeito, apresenta todo seu confabular e, por esta razão, constitui-se como o elo que conduz o relato.

Essa con-fabulação, por sua vez, confere transcendência ao seu sentimento amoroso e se torna verossímil na medida em que Elsa vai estabelecendo a sua identidade na projeção de seus anseios nas coincidências e nas leituras referidas ao longo da narração.

Entre as coincidências, cabe fazer uma referência à maneira muito pessoal como Elsa interpreta os fatos. A forma como conhece Agustín Valdés - pela insistência de um amigo que lhe pede que lhe entregue uma carta - e o reconhecimento do enamoramento já no primeiro contato telefônico revelam, sobremaneira, a fragilidade afetiva na qual se encontra a personagem. Os vários desentendimentos entre ambos e a coincidência gerada pelo livro de Kafka, no segundo encontro, enfatizam a fabulação entorno à impossibilidade de concretização amorosa. Esta impossibilidade, entretanto, transformase, através das leituras e dos simulacros que a envolvem, em transcendência amorosa.

As expectativas de Elsa, portanto, estabelecem-se por meio da interpretação romântica de vários códigos: situações, palavras de Valdés, pinturas e, sobretudo, obras 
literárias, reiterando a epígrafe de El Sur: “¿Qué podemos amar que no sea una sombra?" Ou em palavras recopiladas do diário de Elsa, "Tú eres sólo una sombra y ése es mi mal, pues las sombras no pueden morir" (130).

No que compete à oralidade e sua transcrição é que, astuciosamente enquanto narrativa, o romance nos remete à polifonia que subverte. Em palavras de Elsa "Al parecer no somos nosotros los que manejamos los hilos de la "realidad", sino otros, como se nos dice en La Ilíada que ocurría en Troya" (64). E a alteridade desta narrativa podemos vislumbrar em: Las afinidades electivas, de Goethe, e El silencio de las sirenas, de Kafka.

Mas, antes de empreender nossa análise através desta polifonia, detenhamo-nos um pouco em outro aspecto que opera também o jogo de "caja china" deste mosaico narrativo. As imagens refletidas, ou seja, o contraste de como objeto e imagem se transmutam literariamente à maneira de espelho.

A propósito de um cartão postal com a reprodução do quadro de Ucello, Elsa pergunta a Agustín: “¿No te gustaría ser tan valiente como san Jorge?” (64) Agustín vê Elsa como um monstro (62) - "El sueño de la razón produce monstruos" nos ensina uma das litografias de Goya -, não como uma dama em perigo, que inspire proteção. Não trata, portanto, de resgatá-la de seu mundo como faz o São Jorge de Paolo Ucello. Seria Agustín a dama que não quer ser resgatada?

Este jogo de reversão da imagem também está presente na litografia de Goya deixada por Elsa. Agustín não apenas não se reconhece na projeção de Elsa, como também não manifesta qualquer interesse em corresponder ao gesto que as cartas lhe oferecem. Ele não se re-conhece em Elsa e tão pouco re-conhece Elsa. 
Estas atitudes de Agustín, calculadamente assimétricas às imagens reproduzidas pelas iconografias, reforçam ainda mais a característica ulissiana proposta a partir do relato kafkiano que empresta seu título ao romance.

Enquanto que, já no primeiro telefonema, Elsa se sente hipnotizada por Agustín, este, por sua vez, quando não demonstra uma mera delicadeza de "anfitrião", trata de deixar claro seu total desinteresse em suas desastrosas atitudes. Mas, quanto mais voltado para o seu mundo está Agustín Valdés, tanto mais Elsa se sente enfeitiçada e tentada a seduzi-lo com suas cartas. A beleza que a foto que lhe envia estampa, chega a parecer sobrenatural. Entretanto, Agustín permanece cego e surdo.

A narradora, também em função de leitor ou de narrador kafkiano, expressa sua incompreensão / sua astúcia com respeito à atitude de Ulisses:

Además, no comprendía que Agustín Valdés no estuviera ya fascinado, que las cartas, la voz, el amor de Elsa, no hubieran sido para él un canto de sirena a cuyo sentido ya tenía que haber sucumbido. Por el contrario, a Elsa ni siquiera le había prestado atención. Se había tapado los oídos con cera, igual que Ulises. (143 - negritos nossos)

E Elsa, não consciente desta sua astúcia, resiste e continua alimentando seus desvarios e, também, os da narradora quem, intrometendo-se nesta fabulação, sugere a Elsa que concretize as suas projeções. Diante da recusa da intromissão - deveras metaficional "Qué prosaica eres!" (135) -, María rompe com o seu papel de mera expectadora - leitora da tradição -, e não somente informa a Agustín da verdadeira situação de Elsa, mas, sobretudo, provoca a caída desta num abismo sem volta: como nos alerta Kafka: "De haber tenido conciencia, las sirenas habrían sido aniquiladas aquel día". 
A veces, me empeñaba en imponerle alguna sensatez, pero poco a poco yo misma me fui convirtiendo en testigo de sus ritos amorosos y entregando, igual que ella, a la persecución de una historia fantasma que parecía haber sucedido, o que podría suceder, en un tiempo mítico, en otro espacio. (78 - negritos nossos)

Ao se deixar contaminar pela visão mítica de Elsa e tentar impor o seu ponto de vista objetivo, Maria decreta o fim não somente da fabulação kafkiana; a reversão paródica, vertiginosamente, adquire outros significados, uma vez que também põe fim a fabulação goethiana: Elsa, sob a hipnose, detalhara a trama de Las afinidades electivas como sendo a sua própria experiência, como se a fabulação presente no romance do escritor alemão fosse a memória de sua vida passada.

O romance proibido entre as personagens Otillie e Edward, da obra goethiana, mantém paralelos bastante estreitos com as personagens Otilia e Eduardo, do relato que Elsa faz durante as sessões de hipnose. Esse clássico goethiano se pauta em uma teoria química presente na natureza, a da atração e repulsão de elementos químicos. As personagens se vêem vítimas desta teoria ao se burlarem e colocarem-na à prova em circunstâncias afetivas. Comprova-se, tragicamente, que as convenções sociais ou, ainda, a faculdade intelectiva do ser humano, não permite que as ações naturais se consumem sem algum dano, seja moral ou físico.

A la realidad le gustan las simetrías y los leves anacronismos, diria Borges. Elsa se vale de simetrias presentes em seus sonhos e sessões de hipnose para crer-se Otilia. Assim, se o Edward Otto goethiano relaciona as duas primeiras letras de seu nome, "E" e "O", como sinônimo de que Otillie estava destinada a Edward; Elsa fará a relação de espelho e, então, Elsa está destinada a ser Otilia. 
A Otillie goethiana é uma personagem que se caracteriza pela fragilidade física e psíquica que, por sua vez, revelam-se tanto na forma de se portar em público quanto nas atitudes: delgada, recusa os luxos que a convivência em uma família abastada lhe oferece, tem fortes dores de cabeça e se alimenta pouco (a causa de sua morte, em parte, deve-se a uma provável anorexia), escreve cartas a Edward e, também, tem o hábito de escrever em seu diário. Não suporta conviver sobre pressão, o que a impede de finalizar os estudos. Elsa, além de padecer de fortes dores de cabeça ${ }^{71}$ e se alimentar pouco, de não se importar com sua aparência, deixara de concluir os estudos no conservatório. Entre as duas, entretanto, há o ponto de contato primordial: a impossibilidade de concretização amorosa. Elsa, tal qual a personagem goethiana, tem uma acentuada inclinação para a imobilidade, para o estado contemplativo.

$\mathrm{Su}$ delicada belleza me abstraía de todo lo que me rodeaba, absorbiéndome en ella por completo. $\mathrm{Y}$, ante tan inhumana inmovilidad, pensé que quizás ella no estuviera allí, entre nosotros, sino que, de alguna manera, se habría ausentado y se movería, en aquellos momentos, en otro espacio, entre figuras de realidad imaginaria. Y no me equivoqué, según pude comprobar más adelante, al conocerla. EI reflejo era para ella lo realmente intenso. $Y$ en eso decía que consistía precisamente la vida: en intensidad. No importaba que ésta viniera más del simulacro que de lo real. $(31$ - negritos nossos)

O leve anacronismo - a história entre Otilia e Eduardo acontece em 1864 - é superado pelo suporte que a hipnose, como volta ao tempo através de sugestivas simetrias, confere. Assim, ao equivaler à fabula de Otillie e Edward a de Otilia e Eduardo, Elsa também se apropria do final trágico da personagem goethiana.

A morte de Elsa, em perfeita comunhão com a natureza, parece reforçar o conceito químico exposto por Edward e o capitão em Las afinidades electivas:

\footnotetext{
${ }^{71}$ Ambas sofrem de dores no lado esquerdo da cabeça.
} 
Al fin, en una llanura de un blanco inmaculado, descubrí a su figura, su cabello oscuro, su rostro casi cristalizado. Estaba rígida, inmóvil, adherida a la tierra y formando parte de la montaña, igual que sus plantas, sus árboles, sus rocas, sus piedras... Todo le cubría por igual con la blancura de la nieve. Desde las cumbres más altas, desde el Mulhacén y el Veleta, picos helados e inhumanos, bajaba un viento enérgico que azotaba mi cuerpo. Aquel grandioso y gélido espectáculo se apoderó de mí. Nada podía hacer ni pensar. Al fin me dejé caer junto a Elsa, sobrecogida por el poderoso silencio de las montañas y de la muerte. Y me pareció que ella ahora vibraba con la misma pulsación de la tierra. (165)

Por um outro lado, se o relato kafkiano põe em dúvida a natureza da astúcia ulissiana - se o herói sabia ou não que as sereias silenciaram - a narrativa de García Morales nos relega outra dúvida. Agustín Valdés saberá das conseqüências da revelação de sua total indiferença e permanecerá indiferente a elas? A dúvida, final relegada ao leitor, também é um artifício da narrativa goethiana, uma vez que nas últimas linhas daquele romance, o escritor alemão opta pelo termo "wenn Sie" cuja interpretação cabe tanto para um "se" (condicional) quanto para um "quando" temporal $1^{72}$.

Así descansan los amantes, uno junto al otro. La paz se cierne sobre sus tumbas. Alegres y afines figuras de ángeles los contemplan desde lo alto de la bóveda, y qué dulce será el momento, si en su vida vuelven a despertarse juntos. (GOETHE: 2005, 350 - negritos nossos)

Elsa, ao se entregar à morte, tal qual Otillie, compactua com o rol das personagens femininas que tragicamente renunciam à vida em favor da concretização amorosa além túmulo. Elsa se crê Otillie, a narradora, astuciosamente em sua mimesis, põe em dúvida a reprodução clássica dos suicídios voluntários dos casais amorosos.

Como no retrato de Goethe "la silueta recortada de un rostro de mujer", El silencio de las sirenas dirige o seu olhar para outras obras para refletir, em si e através

\footnotetext{
${ }^{72}$ Esta ponderação é feita pelos tradutores, Manuel José González e Marisa Barreno, na edição espanhola da editora Cátedra. Como se pode notar, os tradutores optaram por uma das formas e, em forma de nota de pé de página, colocaram a informação da ambigüidade deixada por Goethe. Acreditamos que esta ambigüidade contribui para incluir ao casal no rol da tradição de amantes trágicos, que na era moderna se inicia com Romeu e Julieta.
} 
de outras obras, a sua alteridade mimética. Esta figura goethiana é a metáfora perfeita do mise en abyme que se nos oferece a partir de um leitor que lê um texto, que remete a um outro texto e, assim sucessivamente, estabelecendo um alucinante jogo de "vieja caja china".

\section{4 - De Penélope a Sereia: do canto ao silêncio}

A construção da personagem Elsa, como pudemos notar, faz-se a medida em que ela se projeta, através dos sonhos e das sessões de hipnose, em outras personagens literárias. Elsa é a re-presentação destas personagens, por esta razão, quando a inocuidade de seu mundo se revela, sua presença se desintegra:

Bañado por la luz de la luna, el rostro de mi amiga parecía el de una figura de cera. Percibí en él algo inhumano, algo irreal. (157 - negritos nossos)

Mientras hablaba, lentamente, casi sin aliento, observé que había sufrido una transformación. Ahora tenía un aire de muñeca, de figura irreal. Al andar sus brazos permanecían inmóviles, rígidos, pegados a su cuerpo. Había adquirido el aspecto de una anciana, cuyos movimientos tenían que luchar contra unas articulaciones casi cristalizadas. (158 - negritos nossos)

De sua vida anterior ao seu estado catatônico, apenas temos notícia de que exercera a docência, abandonara as aulas de piano num conservatório, a casa na qual vivia pertencia a um amigo que gentilmente lhe cedera para que pudesse se curar de uma pneumonia ${ }^{73}$. Mas, a sua persona se reveste de pelo menos duas anti-faces ${ }^{74}$. A de penélope e a de sereia.

\footnotetext{
${ }^{73}$ A partir desta perspectiva, poderíamos estabelecer um paralelo com a Montaña Mágica: o mundo que mobiliza as personagens de García Morales lhe são tão intangíveis quanto o mundo, a pretensa "realidade" que as circunda.

${ }^{74}$ Como sugerem as reproduções do retrato de Goethe e da litografia de Goya.
} 
Seu lado penélope parece ser o mais prosaico. Elsa é a que espera e a que trama a narrativa. Como nos assinala Inácio Costa:

[...] no universo épico onde se situa a narrativa homérica, são recorrentes as imagens ligadas ao trabalho de tecer: o rapsodo, artesão que recolhe e costura as narrativas dispersas da tradição oral, é, por isso mesmo, cantor que costura os cantos; Palas Atena, a deusa cúmplice de Ulisses, é também uma deusa tecelã e, como tal, conduz não apenas a difícil viagem do herói mas também a trama narrativa do poema; duas outras importantes figuras femininas da Odisséia, Circe e Penélope, são igualmente exímias tecelãs e, ligadas a momentos decisivos da narrativa, remetem às inúmeras afinidade entre o trabalho de tecer e a arte de narrar. À estrutura narrativa do poema homérico é possível associar a imagem de uma trama que se tece a partir de muitos fios e muitas mãos: várias histórias narradas e diferentes focos narrativos se entretecem para compor aos poucos um múltiplo tecido narrativo. $(2005,20-1)$

Com pequenas diferenças do assinalado por Costa - e guardadas as devidas reservas, pois não estamos lidando com um texto épico, mas sim com o mito que ele aporta e sua re-leitura subversiva -, podemos notar que como na Odisséia, El silencio também se constitui de uma trama que se tece a partir de muitos fios e mãos e que a mesma história é narrada de diferentes focos e, principalmente, através de diferentes formas narrativas.

Sobre o primeiro aspecto, o foco narrativo e estrutural, Ciplijauskaité (1988, 170) salienta o caráter de espaço aberto da narrativa, que apresenta, segundo a estudiosa, três modos diferentes de perceber a mesma realidade, "yuxtaponiendo el discurso amoroso de Elsa, el comentario con miras de objetividad por parte de María, y la percepción de la realidad por Matilde y las otras mujeres del pueblo (mundo de la superstición).”

Desde o ponto de vista do segundo aspecto, o das formas narrativas, é que percebemos a intertextualidade, que a narrativa que se faz de narrativas. Podemos interpretar Elsa como uma sereia moderna. A narrativa recupera o mito para reverter, ou 
melhor, problematizar a questão da ausência: na obra homérica de um fim para as sereias, na kafkiana de recuperação da voz que se cala. A partir destas prerrogativas, Elsa, em função de sereia híbrida penélope, tece o seu canto e Agustín, em função de Ulisses, se mantém indiferente ao seu canto, parece ter tapado os ouvidos.

A repetição dos atos, como no relato kafkiano, adquire outro significado através da alteridade que a ruptura agrega à tradição. Apesar de a narrativa relegar, com este ato, a sereia / Elsa à morte, tal como podemos supor no texto homérico; este resgate do suicídio adquire o "peso da história" - como diria Borges em Piere Menard -, uma vez que ele evoca claramente a tradição de sua leitura através do texto kafkiano: o Ulisses, no caso Agustín, continua atado a seu mundo egocêntrico de “ceras y cadenas".

A subversão do relato kafkiano se pauta exatamente na mudança da voz que transmite a tradição. Trata-se de uma narradora, Maria, que em função de penélope, recupera um outra tradição de transmissão esquecida, a da voz feminina: o canto da sereia / Elsa nos é transmitido, não oralmente, mas através da escrita, uma escrita que, por sua vez, destece o relato num movimento meta-ficcional.

Notemos como os movimentos de tradição oral, presentes na épica homérica que nos chega através do texto escrito, são retomados. Kafka o faz através de uma reversão, que astuciosamente, propõe como uma alteridade do próprio relato homérico "la tradición añade". García Morales os recupera transversalmente na estrutura narrativa e no jogo de simulacros intertextual inerentes a ela.

Neste sentido, como já referimos, María além de narradora / penélope, cumpre o papel de um leitor privilegiado. É ela quem conhece a trama e é também quem lhe conferirá a cadência e a forma do discurso. O leitor adquire maior vulto quando nos apercebemos de que a leitura de María passa pelos olhos interpretativos de outro leitor: Elsa. 
É Elsa quem lê as obras de Kafka e Goethe. É ela quem, através de sua leitura e projeção interpreta a sua história e, ao fazermos o mesmo caminho interpretativo e seguirmos as "pistas" deixadas por ela e criteriosamente montadas por María, não fazemos senão reproduzir seus mecanismos de análise e associação. Parece que, como Elsa, estamos hipnotizados.

É interessante notar que a desenfreada paixão de Elsa em oposição à conduta - e também ao ato narcísico - de Agustín, é interpretada por Matilde como "mal de ojo". Currie K. Thompson em seu artigo "El silencio de las sirenas: Adelaida García Morales revisión of de femine 'seescape"” $(1992,298)$, concentra sua análise no poder que a imagem e o olhar penetrante tem em El silencio, pelo fato de que o título, enquanto a ausência de som, reforça a importância das imagens que, por sua vez, remetem ao poder dos olhos, do olhar.

Assim exposto, Las Alpujarras estão localizadas "entre silenciosas cordilleras"(14), ao chegar ali, Maria sente e descreve o vento que "crecía la intensidad del silencio que silvaba en mis oídos"(14), as montanhas têm "su silencio perfecto" (17) e, Matilde que é descrita pelos "rumores...constituidos más por silencios y miradas temerosas que por palabras" (19), afinal de contas, de acordo com a crendice, quem tem o poder de curar o "mal de ojo" também tem o de matar através dele.

Tanto a representação da morte de Elsa quanto a de Ottilie, segundo a estudiosa norte-americana $(1992,299)$, refletem o congelamento da imagem, proporcionada pelo olhar do artista, arquiteto e narrador. Ou seja, de alguma personagem, do narrador ou da intertextualidade referida na obra. A arte de reprodução mimética adquire, portanto, poderes mortais. 
A referida estudiosa nos remete ao fato de que os jogos de encenações, com os quais se divertem as personagens de Las Afinidade Electivas ${ }^{75}$, refletem imagens congeladas que se reproduzem na obra. Um dos quadros é Belisario, do pintor A. Van Dyck, ao qual o Arquiteto - personagem secundária na obra de Goethe - refere-se ao visitar o túmulo de Ottilie.

Entendemos, desde o mesmo ponto de vista da estudiosa que, por um lado, os jogos que entretinham as personagens nada mais revelam que uma crítica goethiana irônica aos simulacros sociais: os quadros que revelariam situações sociais, nada mais fazem que revelar convenções sociais. Por outro lado, a figura de Ottilie havia sido congelada pelo Arquiteto nas imagens reproduzidas nos teto da capela, lugar fúnebre por natureza; esta sim seria uma mostra clara e, por que não, oracular do final trágico de Ottilie:

Con una práctica continuada, Ottilie y el Arquitecto consiguieron más libertad en las últimas imágenes; habían mejorado visiblemente. También los rostros, cuya realización se había reservado el Arquitecto, mostraba poco a poco una cualidad especial; todos comenzaban a parecerse con Ottilie. [...] Para acabar, uno de los rostros quedó tan perfecto que pareció como si la propia Ottilie mirase desde los espacios celestiales. (GOETHE: 2005, 221-2 negritos nossos)

A Otilia que projeta Elsa em seus sonhos e sessões de hipnose, entretanto, tem

um final diferente da goethiana, mas igualmente trágico:

- La playa está vacía y hace mucho frío. En la arena, junto a mí, hay láminas de hierro cubiertas de robín. Están agujereadas. Presiento algo horrible... Un dolor insoportable. No veo nada... Se me van todas las imágenes... Ahora llega Edward. Ha envejecido muchísimo. Su pelo, muy alborotado, se ha vuelto blanco, sus mejillas están muy afiladas, sus ojos se mueven inquietos de un lado a otro con una mirada desapacible. Es la locura. Ese es precisamente su aspecto: el de un loco. Apoya sus manos en la balaustrada blanca

\footnotetext{
75 Por uma questão de clareza com relação às tramas de El silencio de las sirenas e Las afinidades electivas, ao referirmos às personagens da trama de Goethe, usaremos os nomes tal qual aparecem na obra do autor, Ottilie e Edward. Por sua vez, aos nos referirmos às personagens que aparecem no relato da personagem Elsa, de García Morales, utilizaremos Otilia e Eduardo, como aparece neste romance.
} 
que tiene delante. Desde allí contempla una playa donde se ven restos desperdigados de barcos destrozados. Allí he muerto yo. Lo sé. Y por eso él contempla ese lugar cada día. Mi muerte ha sido horrible. Él lo sabe. Pero yo no puedo recordar nada. Sólo tengo impresiones vagas y lejanas que me asustan. (112)

Com efeito, a morte descrita por Elsa se assemelha mais à morte referida no conto kafkiano. E, de fato, Elsa se vê como uma sereia e se admite como o monstro que Agustín temia: “Al dolor de perderte se unió entonces el miedo a que descubrieras mi monstruosidad: yo no era en realidad una mujer, sino una sirena". Uma sereia como as descritas na Odisséia, metade pássaro, metade peixe que, ironicamente, decide morrer não no mar, mas nas montanhas, perto do céu em perfeita harmonia com seu espaço.

Currie, no seu estudo, apóia-se em Lacan para nos aportar que "Apparently the artist's gaze is as fatal as the evil eye of the hypnotist, which deadens vision”, já que "The evil eye is the fascinum, it is that which has the effect of arresting movement and, literally, of killing life" (The Four, 115, 118 apud CURRIE: 1992. 299 - negrito nosso). Esta metáfora, empregada na interpretação deste romance de García Morales, ganha ao nosso ver uma especial e jocosa ironia: o "mal-olhado" é o estado ao qual, nós leitores, estamos fadados a entrar ao lermos um livro. Elsa, com efeito, reproduz a figura quixotesca, a flauberiana...

Não é casual, então, que tema a realidade, afinal de contas, ela mesma é um jogo de simulacros - outra comparação borgiana se faz pertinente, neste caso ao conto "Las ruinas circulares". Portanto, se o espaço físico são Las Alpujarras, o mental ou o da leitura é, com efeito, aquele que deveras im-porta significativamente: "espacios irreales" (46), "un lugar inmaterial", "ese otro lugar donde suceden los sueños" (55), “Aquella tiniebla suya de la que parecían brotar insistentes imágenes de amor y de muerte.”(67). O jogo de repetições, se por um lado aliena a personagem que busca cumprir o seu fim 
oracular, por outro, perverte, com seu livre arbítrio, as imagens já difundidas do suicídio feminino: por afogamento, um suicídio na própria alcova ou precipitando-se de uma janela $^{76}$. A sua morte se constitui de um belo quadro, a ponto de a narradora não querer desmantelá-lo.

Oscilando nas fronteiras lábeis entre o silêncio e o grito, o desespero e o protesto, este gesto de Elsa liga-se ao passado e acena, de forma subversiva, ao porvir, insinuando-se no quadro das mudanças sociais, mas, sobretudo, na forma como se concebe e se lê a estrutura narrativa e a tradição que o romance moderno aporta. É por esta solução trágica, mas ambígua, que Elsa alça-se ao plano das emblemáticas personagens femininas e se associa às figuras paradigmáticas clássicas, sempre tão vivas na nossa lembrança.

O silenciar das sereias kafkianas. A imagem poética do suicídio de Elsa entre a paisagem. Um único detalhe, por ser essencialmente subversivo, é por si só capaz de concentrar toda a força que imprime ao texto a sua forma e a sua identidade, mais do que qualquer noção de verossimilhança externa.

O olhar que congela, tal qual Medusa a terrível górgona, representa neste contexto a possibilidade de ruptura desta cadeia infinita de repetições, senão da mesma cena trágica, pelo menos de seu sentido trágico, no também possível metáfora metaficcional.

Mais que "ver" e "ser vista" - conforme propõe Currie K. Thompson - a dialética intrínseca de El silencio de las sirenas é a leitura e a suas possíveis

\footnotetext{
${ }^{76}$ Nicole Loraux $(1988,112)$, explora o caráter literário e social do suicídio na antiguidade clássica e chama-nos a atenção para o fato de que de Ésquilo a Sófocles e de Sófocles a Eurípedes, todas as mortes femininas são apenas referidas, elas não acontecem em cena: "o paradoxo da morte gloriosa das mulheres é que a única morte bela é a viril"(112); que "as noções e as escolhas intelectuais "mudam" (evoluem, diz-se)". Neste sentido, as palavras de Paul Veyne podem adquirir outro significado que não o social-histórico: "O horror pelo suicida é revelador de uma ditadura moral de todos sobre todos, e tal ditadura é comum a muitas estruturas sociais, regimes autoritários, autodisciplina militarista, censura paroquial, onde a conduta de cada um é ressentida como desafio à autoridade de todos os outros".(apud, CARVALHO $(1990,43)$
} 
interpretações, em outras palavras, "ler" e "ser lida". E mais uma vez, antevemos nesta dialética a ironia presente dicotomia romancesca homem versus mundo. Segundo Lukács,

na medida em que configura a realidade como vencedora, a ironia revela não apenas a nulidade do mundo real diante de seu adversário derrotado, não apenas que essa vitória jamais pode ser definida e será reiteradamente abalada por novas insurreições da idéia, mas também que o mundo deve sua primazia menos à própria força, cuja grosseira desorientação não basta para tanto, do que a uma problemática interna - embora necessária - da alma vergada sob os ideais. $(2003,87)$

A "vieja caja china" vazia que Elsa deixa é o silêncio, é o espaço narrativo que se cala, um convite para que o leitor possa atuar e preenchê-la de sentidos. E, como no romance, voltamos ao começo.

A epígrafe de Fernando Pessoa, presente no início da obra, pertencente ao heterônimo Álvaro de Campos, é um poema do Cancioneiro intitulado "Realidade", que envolve e também sugere a leitura interpretativa do romance (a frase, que é citada no romance, contém negritos nossos):

$[\ldots]$

Tento reconstruir na minha imaginação

Quem eu era e como era quando por aqui passava

Há vinte anos...

Não me lembro, não me posso lembrar.

O outro que aqui passava, então,

Se existisse hoje, talvez se lembrasse...

Há tanta personagem de romance que conheço melhor por dentro

De que esse eu-mesmo que há vinte anos passava por aqui!

Sim, o mistério do tempo.

Sim, o não se saber nada,

Sim, o termos todos nascido a bordo

Sim, sim, tudo isso, ou outra forma de o dizer...

Daquela janela do segundo andar, ainda idêntica a si mesma,

Debruçava-se então uma rapariga mais velha que eu, mais lembradamente de azul.

Hoje, se calhar, está o quê?

Podemos imaginar tudo do que nada sabemos.

Estou parado física e moralmente: não quero imaginar nada...

Houve um dia em que subi esta rua pensando alegremente no futuro, 
Pois Deus dá licença que o que não existe seja fortemente iluminado,

Hoje, descendo esta rua, nem no passado penso alegremente.

Quando muito, nem penso...

Tenho a impressão que as duas figuras se cruzaram na rua, nem então nem agora,

Mas aqui mesmo, sem tempo a perturbar o cruzamento.

Olhamos indiferentemente um para o outro.

E eu o antigo lá subi a rua imaginando um futuro girassol,

E eu o moderno lá desci a rua não imaginando nada.

Talvez isso realmente se desse...

Verdadeiramente se desse...

Sim, carnalmente se desse...

Sim, talvez...

\section{5 - A sinfonia do silêncio}

Maureen Tobin Stanley (s/d, 1), em seu estudo "Una Visión Alterna Ante La Dicotomía Mítica: La Hibridación De Penélope y Las Sirenas en El Silencio de Las Sirenas de Garcia Morales", seguindo a tradição da leitura crítica feminista, problematiza que a reversão e a refundição das duas figuras míticas, Penélope e Sereia na personagem Elsa, põe em voz de mulher a "contra-épica" de duas figuras secundárias para romper com a dicotomia Ave-Eva. Baseando-se em estudos da feminista francesa Hélène Cixous e de Paul Ilie, Stanley afirma que esta operação mimética da escritora "sirve para dar voz a las figuras femeninas antiguamente silenciadas" (s/d, 2).

Percebemos esta recuperação, não obstante o estudo de Stanley, através de um processo estrutural mais complexo que o de reversão das metáforas intrínsecas aos mitos explicitamente referidos. Há um cuidadoso trabalho de arquitetura da estrutura narrativa em busca do sentido pleno do canto e do silêncio sugeridos pelas figuras míticas, ou parafraseando Francisco Costa, do "como" sobre o "que".

O gesto, linguagem mimética do corpo, adquire importância como postura narrativa. É com descaro que os habitantes de Las Alpujarras olham; é com “ar" e 
atitudes de superioridade que Matilde se impõe à Maria e, com a prática de ritos, que se impõe aos habitantes; Maria conquista a amizade de Elsa pelo que não é, como hipnotizadora; Elsa, por fim, é a própria metáfora narrativa: a sua atitude alienada do mundo, que se assemelha ao espaço físico de Las Alpujarras, justapõe-se como uma das figuras mais intertextuais e subversivas entre as personagens de meta-ficção. Esta dialética - do ser no estar e do deslocamento do tempo no espaço - objetiva recuperar aquele canto silenciado pelo Ulisses-aedo, ou antes, aquela voz que ante o perigo iminente, kafkianamente, calou-se.

O espaço converte-se em peça chave transgressiva. Na odisséia de recuperação da voz silenciada, parece haver um conflito deflagrado entre o espaço narrativo e a personagem. Elsa se move entre Alemanha, Barcelona e Veneza. Nestes espaços ela se materializa, ela age. Em Las Alpujarras, entretanto, ela se concretiza através das palavras. A escolha do lugar de materialização da palavra tanto oral quanto escrita oferece, pelo menos, duas justificativas. A primeira já aportada pela descrição da narradora:

Y, sin embargo, cuando dejé atrás la venta de Las Angustias y entré en Las Alpujarras, tuve la impresión de cruzar una frontera precisa y de penetrar en un mundo extraño que se volvía hacia sí mismo, encerrado en una inquietud intemporal. (14)

Esta característica espaço-temporal estática adquire maior relevância quando recorremos ao seu aspecto histórico e místico. Último refúgio mourisco em território espanhol, a região está marcada por um peso histórico que, muitas vezes, mistura-se ao lendário, por muitos que sejam os esforços dos antropólogos e historiadores em desvinculá-los (BARRIOS AGUILERA: 2001, 85).

É este por excelência o lugar de resistência mourisca, é o lugar onde se acredita que ainda perambulam espíritos de uma tradição mística que os espanhóis querem 
esquecer ou, antes, silenciar ${ }^{77}$. Lugar ao qual podemos vincular as vozes femininas das raízes literárias espanholas. Aquelas vozes mouras de Al Andalus que esperam ser ouvidas, junto às sereias ulissiana e kafkiana. É como Scherazade que Elsa, nas sessões de hipnose que acontecem ao anoitecer, adia a sua morte, seduzindo com sua narrativa a Maria. Desta forma, vincula-se às lendárias sereias para reverter o seu silêncio. A sua história mais do que o infinito adiar da morte sugerido nas Mil e uma noites, revela-se como um relato da liberdade de expressão quanto ao seu destino, tantas vezes usurpado, silenciado, pela tradição literária, seja universal, seja nacional.

Mas, se nos detivermos um pouco mais na funcionalização deste espaço, deflagramos seu aspecto estruturador como ambiente. Las Alpujarras, conforme a descrição da própria narradora, é habitada praticamente por mulheres e, em sua maioria, já maduras. Não obstante esta especificidade e a polifonia já aludida, a trama se delineia a partir da sombra masculina, como em La casa de Bernarda Alba: drama de mujeres en los pueblos de España.

Segundo Ruiz Ramón, estudioso da obra loquiana:

El universo dramático de Lorca, como totalidad y en cada una de sus piezas, está estructurado sobre una sola situación básica, resultante del enfrentamiento conflictivo de dos series de fuerzas que, por reducción a su esencia, podemos designar principio de autoridad y principio de libertad. Cada uno de estos principios básicos de la dramaturgia lorquiana, cualquiera que sea su encarnación dramática - orden, tradición, realidad, colectividad, de un lado, frente a instinto, deseo, imaginación, individualidad, de otro - son siempre los dos polos fundamentales de la estructura dramática. (1971, 171 - itálico do texto)

Em palavras dos estudiosos Allen Josephs e Juan Caballero (2000, 72), esta “situação básica” referida por Ruiz Ramón, em La casa de Bernarda Alba, alcançou um amadurecimento da técnica dramática de uma tal forma que pode ser lida como "la

\footnotetext{
${ }^{77}$ Matilde, como personagem autóctone, revela-nos parte desta tradição.
} 
expresión más radical del tema del conflicto entre el individuo y la sociedad”. E no que tange à ação ou ao argumento, centra-se no que não acontece na casa, ironicamente presente no título da obra. Em outras palavras, todo o dramatismo está presente na linguagem, no que se diz e no que não se diz $(2000,79)$.

É a partir destas chaves interpretativas que nos parece que El silencio se aproxima desta obra maestra do escritor, poeta e dramaturgo andaluz. Na obra da escritora estremenha se deflagra, enquanto mimesis social, um conflito entre Elsa personagem principal - e Maria e Matilde, representantes, respectivamente, da sociedade a qual ela pertence, cidade, e na qual ela vive, Las Alpujarras.

Maria, com sua forma de interpretar e de agir objetivamente, instaura o conflito com a forma subjetiva e mítica de Elsa ao querer tirá-la tanto do universo mítico quanto do literário, para trazê-la a uma realidade mais tangível. Esta é um das condutas narrativas que proporciona a verossimilhança do relato e de sua personagem. Por um outro lado, é este também o ato mimético de representação do poder que silencia a voz da sereia para, depois, recuperá-lo como discurso fragmentário. Parece ser a culpa o motor estruturador do relato de Maria, desde esta perspectiva parece ser um ato de expiatório.

Já Matilde, está entre o objetivo e o subjetivo, a sua forma de interpretar o mundo parte de uma noção muito subjetiva, mística. Entretanto, no que se refere a alguns aspectos práticos, sua reação é objetiva. Se por um lado acredita no poder do mal-olhado e inclusive é capaz de curá-lo, Matilde sobrevive como pequena comerciante e se mostra cética quanto à hipnose realizada por Maria. Estas peculiaridades antagônicas que formam esta personagem também contribuem para estabelecer um choque com o mundo no qual vive Elsa. Matilde deseja curar com suas 
crendices o "mal" que atormenta a personagem. A culpa por não conseguir se converte em doação de seu nicho, um lugar digno e iluminado todos os dias pelo sol.

Não obstante a opressão que estas duas personagens representariam, é a sombra masculina que impulsiona a odisséia literária que nos proporciona Elsa. Não são as suas escassas palavras que importam para o desenvolvimento da trama, mas o seu silêncio, a sua ausência enquanto presença física. Como na obra de García Lorca (JOSEPHS et CABALLERO: 2000, 93-4), El silencio de las sirenas não é uma narrativa acerca do amor, mas de "su falta, su truncación, su ausencia, su elipse. Todo ello dentro de un sentido de mortandad hiriente e inevitable" e que marcam a repressão da individualidade ${ }^{78}$.

A relação de personagens femininas fatais é prolixa - entre elas, as clássicas, Julieta, Tisbe, Hera, Isolda - e, nem por isso, deixa de fazer parte do imaginário popular. A sublimação do amor, consagrado na morte em El silencio, entretanto, sofre uma reversão irônica. Não é o cavalheiro-servo quem morre ou se suicida. É a dama. E, talvez, ele nem saiba que foi a "válvula propulsora" do ato subversivo.

Ciplijauskaité $(1988,172)$ associa esta subversão da obra de García Morales à tradição de Liebestod e, mais especificamente à obra dramático-musical de Wagner, uma vez que no romance chama a atenção à insistência no "espaço musical", indispensável para a projeção do mundo onírico de Elsa. A data de 1864, segundo a

\footnotetext{
${ }^{78}$ A morte e a transcendência amorosa, por um outro lado, é um dos temas mais visitados na literatura universal e encontra seus ecos mais expressivos na poesia lírica espanhola e García Lorca é um de seus grandes expoentes.

O emblemático soneto "Amor constante más allá de la muerte", de Francisco de Quevedo, apontado pelos críticos como o mais belo e perfeito escrito em língua espanhola, leva-nos em outra direção ao interpretarmos o romance de García Morales em consonância com o final de Las afinidades electivas ${ }^{78}$. Principalmente se nos concentrarmos em seus versos finais:

Alma a quien todo un dios prisión ha sido, venas que humor a tanto fuego han dado, medulas que han gloriosamente ardido:

su cuerpo dejará, no su cuidado; serán ceniza, mas tendrán sentido; polvo serán, mas polvo enamorado.
} 
estudiosa, estaria intrinsecamente associada à presença de Wagner naquele país, cujo trono é ocupado por Luis II:

Es conocida su admiración por Wagner, quien reside como su invitado en Baviera de 1864 a 1865, y para cuyas óperas concibe el teatro de Bayreuth; con escenas de ellas está decorado al fresco su castillo de Neuschwanstein, castillo de muchas torres. Luis II termina su vida al ahogarse en el lago de Starnberg. Su pasión por la música, que rayó en locura, su rechazo de todo lo que no era belleza y espíritu le emparentan con Elsa y su locura de amor. (Idem)

Vemos, não obstante o paralelo feito pela estudiosa lituana, uma maior afinidade entre a personagem Elsa e sua obra preferida de Morzat, o concerto para piano número 27. Esta foi a última obra composta pelo músico austríaco e, também, a última cuja execução ele ouve antes de sua morte. Mozart, como Elsa com relação ao seu relato, deixou o seu Requiem para que alguém o concluísse.

Segundo Walter Benjamin (1991, 111-34), o narrador é um homem que dá conselhos, ele se assemelha ao antigo contador de estórias. Parece ser esta a maior herança que Elsa relega à narradora. Maria a herda de forma eficaz e a demonstra transversalmente na dissimulação, o mesmo escudo usado no relato kafkiano como a verdade outra do evento lendário relatado por Homero.

Se o Quixote se revela por sua desorientação e descompasso - numa leitura desconstrutiva do também renitente viajante Ulisses -, estes atributos se convertem em dissimulação no novo contexto mimético. O conselho, convertido em dissimulação, é de fato menos uma resposta a uma pergunta do que uma proposta que diz respeito à continuidade de uma história que se desenvolve através da polifonia. Este fingimento revela e reitera uma vez mais o descompasso entre o indivíduo e o mundo hostil ou falho de sentido. 
O jogo dialético narrativo levado a seu extremo - o paradoxo - nesta narrativa através da dicotomia palavra / silêncio inscreve, não por acaso, o esforço de exploração dos limites do ato tradicional de narrar e, por sua vez, apresenta a sua inviabilidade que não seja por meio do processo de dissimulação intertextual, polifônica.

A narradora, desde este ponto de vista, reitera o seu papel de sensor, ela o faz através de uma estratégia de renitente articulação dialética entre des-memória, reprodução / omissão das cópias das cartas e do caderno / diário deixados por Elsa. Tal estratégia expõe de forma eficaz os bastidores do processo deformativo de estruturação da narrativa. E é aí que encontramos, mais uma vez, a ironia: o relato somente nos revela o que lhe é conveniente, ou antes, o que para o narrador parece ser relevante. Portanto, compete a nós leitores, resgatar neste labirinto estrutural, as entrelinhas da manipulação discursiva.

Como nos assinala Luis Inácio Costa (2005, 293-4), com relação ao texto kafkiano, e que transpomos a esta obra de García Morales, este traço do narrador "promove uma descontextualização destrutiva e produtiva da tradição épica", o que, acrescentamos, contribui para a manutenção da experiência narrativa e, desta forma, reitera a operação kafkiana de transformar a palavra mítica em palavra-narrativa.

O tratamento dado ao tempo, que pretensamente se vincularia ao espaço de forma conveniente, dialeticamente aproxima-se na mesma medida em que se distancia do proustiano. A válvula propulsora deste movimento, o anel que se transforma em pêndulo, com certa ironia carrega em si tão somente uma lembrança fugidia, sem peso significativo que o vincule ao passado: Elsa o herdara de sua tia avó, e o anel, de tão grande, "dança" em seu dedo. Mas, ao se funcionalizar como elo que firmará o vínculo da personagem com sua característica inerentemente ficcional, adquire o valor de uma 
aliança que irmana a intertextualidade. Não é casual, portanto, que a narradora também o herde.

O jogo temporal - resgatado nas referências a Kafka e a Proust - sugere dois movimentos. No primeiro o silenciar do presente seria a prerrogativa para dar voz ao passado. No segundo, a transgressão desta voz instituiria o presente como experiência, denunciando a precariedade do eterno (mito) e estabelecendo a sua conquista. Se o outro era o tempo do silencio o presente é o de sua subversão como passado que se reflete no presente.

E como uma palavra leva à outra, uma obra leva à outra e os silêncios se afinam em um uníssono, percebemos que a dialética inicialmente gerada pelo título - El silencio de las sirenas - como referência à narrativa kafkiana, faz-se ressoar como eco: ao repetir apenas parte das palavras e forma propagadas pela tradição, Elsa e a narradora astuciosamente revertem a posição da voz feminina na tradição literária. 
Con varios vocablos rehace una palabra total, nueva, extraña a la lengua.

Mallarmé, Avant-dire

El texto no es una cosa, por lo tanto la otra conciencia, la del que lo recibe, no puede ser eliminada ni neutralizada.

Las ciencias humanas son ciencias que estudian al hombre en su especificidad, y no como cosa sin voz o fenómeno natural. El hombre en su especificidad humana siempre se está expresando (hablando), es decir, está creando texto (aunque este sea un texto en potencia).

Un acto humano es un texto en potencia y puede ser comprendido (como acto humano, no como acción física) tan sólo dentro del contexto dialógico de su tiempo (como réplica, como postura llena de sentido, como sistema de motivos).

M. Bakhtin, Problemas de la poética de Dostoiévski

- ¿Quién eres tú?

Esperó a que el eco de la voz se apagara, se imaginó a sí mismo sobre su mesa de trabajo, escribiendo la novela de su vida, y respondió:

- Yo soy el que nos escribe, el que nos narra.

Juan José Millás, El desorden de tu nombre 


\section{CAPÍTULO IV}

\section{1 - Uma estrutura, múltiplas viagens}

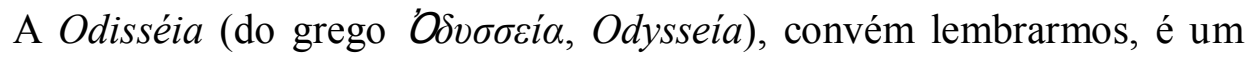
poema épico que canta o nostos, palavra grega que significa "regresso" (de onde se deriva a palavra portuguesa "nostalgia"). O título formado pelo nome Odisseu

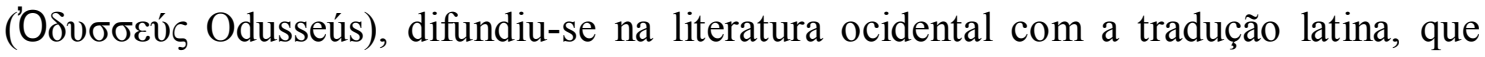
conservou o título desta épica em grego, não obstante haver traduzido ao latim o nome da personagem. Talvez pelo desconhecimento do vínculo Odisséia-Odisseo-Ulisses, a palavra "odisséia" passa a significar "viagem cheia de aventuras e peripécias", ou ainda, "série de complicações, peripécias ou ocorrências singulares, variadas e inesperadas" (FERREIRA: 1986, 1214), muitas vezes dessociada dos sentidos intrínsecos àquele universo fechado da epopéia homérica.

No romance moderno, a "odisséia", ou antes, a "viagem" - presente já no Quixote -, mais do que um tema caracteriza-se, sobretudo, como um elemento organizador da estrutura narrativa. O caráter fundacional e de constituição identitária de um povo, por sua vez, cede lugar ao do indivíduo.

Mas se, por un lado,

[...] todo en la novela tiene una forma en el discurso y se utiliza como elemento arquitectónico, y todo puede ser interpretado en relación al sentido general de una lectura, y todo puede incluirse en la red de relaciones pragmáticas del texto con los sujetos del proceso de comunicación literaria que inicia la novela y con los valores del mundo empírico (BOBES NAVES: 1993, 107). 
Por outro, o leitor / receptor, por sua vez, terá um papel atuante, uma vez que, como já assinalava Jakobson, será ele quem transformará a potencialidade das palavras em ato comunicativo.

Ao analisarmos os romances, objeto deste estudo, sob o aspecto de obras essencialmente polifônicas, estamos colocando em evidência nossa função de leitor e os mecanismos de produção de sentido entre o referido pela narrativa e o que pontuamos pela inferência de nossa experiência enquanto leitores da tradição incomum e particular a cada romance.

Neste sentido, se levarmos em consideração os três modelos de mundo propostos por Tomás Albadejo (1986, 58-9) ao estabelecer a macro-estrutura narrativa - a saber: aquele no qual se estabelece uma correspondência precisa entre o mundo real e o criado pelo discurso, presente nos textos históricos; um outro no qual os mundos ficcionais apresentam a sua própria regra, mas que ponderadamente segue as estabelecidas no mundo real objetivo; e finalmente, o terceiro, cujas conexões entre as regras do mundo real e do imaginário criado pelo autor são menores -, veremos que a função do leitor se viabiliza como a de delimitar a fronteira lábil entre o mundo real e o criado pela narrativa.

Não obstante ambos romances, Uma aprendizagem ou o livro dos prazeres e El silencio de las sirenas, valerem-se da viagem como elemento estruturador da narrativa, além de apresentarem elementos intertextuais comuns em uma clara intenção de releitura subversiva do mito de "Ulisses e Penélope", o princípio estruturador de cada périplo contém as particularidades inerentes às suas tensões, ou ainda, ao centro mimético abarcado na constituição do indivíduo em choque com o seu mundo. Este 
princípio estruturador - como já aludimos - permite diferentes leituras da obra, em outras palavras, segue a cadência da experiência do leitor ${ }^{79}$.

$\mathrm{O}$ indivíduo em choque com o seu mundo. A viagem como princípio estruturador. O leitor como vértice viabilizador deste tripé narrativo ${ }^{80}$. Vejamos como a “odisséia" estrutura cada romance e nos oferece pontos de contato e de singularidade.

Horácio, em sua "Carta aos Pisões", ao se referir à poética de Homero, utiliza o termo "in medias res" para designar a estrutura temporal de sua epopéia, uma vez que o poeta grego insere os seus leitores no "meio das coisas", ou seja, no "meio da ação" para, através de flashbacks, desenvolver parte da trama, como é o caso da narração de Ulisses na corte dos feáceos ou, ainda, do episódio da cicatriz, tão detidamente analisado por Auerbach.

Na Odisséia, particularmente, Homero não apenas nos insere no meio da ação, como também a congela para desenvolver outra, a Telemaquia, que tem lugar nos quatro primeiros cantos, nos quais Telêmaco, filho de Ulisses, realiza seu périplo em busca do pai.

Em Uma aprendizagem, o conceito de in medias res, não obstante o seu caráter espaço-temporal, reside no próprio uso da linguagem narrativa: tempo e espaço narrativos coincidem com o discursivo da personagem. Vale retomar o já mencionado, estamos "no meio do caminho". E esta inserção no discurso, de forma tão abrupta,

\footnotetext{
${ }^{79}$ Apesar de o romance de García Morales ser posterior ao de Clarice Lispector e de a autora ter participado da Semana do Livro de 2002, em Barcelona e, em especial, de uma "oficina literária" cujo tema era a escrita feminina e uma das autoras referidas era Clarice Lispector, não podemos afirmar que García Morales sobre influências da obra clariciana.

${ }^{80}$ São também elementos que compõem o Bildungsroman. Zulema Moret (2000, 178-80) detalha, em seu estudo, as características do romance de formação; dentre elas, cabe salientar: "El Bildungsroman configurará la forma moderna de la novela a través de la construcción de un joven héroe que crece entre las tensiones que operan entre su subjetividad y su entorno", "la novela de formación es una novela didáctica. Se educa al lector mediante la representación de la educación del héroe" e "Son novelas narradas en primera o tercera persona, pero es necesario aclarar a posición irónica del narrador respecto al protagonista", a seguir a estudiosa se detém em verificar entre alguns romances hispano-americanos como estas características se adaptam. Segundo a definição de "odisséia" já aludida, podemos supor que o romance de formação se constitui de uma "odisséia", no sentido de que a personagem passa por uma "série de acontecimentos trágicos e variados" para concluir a sua aprendizagem.
} 
retoma a tradição do périplo odisséico através de uma releitura, cuja metis narrativa, não cinde com as convenções da estrutura romancesca, pelo contrário, ela as reforça através da recuperação do in medias res também na forma discursiva.

A viagem que esta narrativa clariciana nos proporciona, portanto, vai além dos limites da ação, ela bordeja dois universos outros: o interior do discurso narrativo em formação e a experiência da autora.

Como já tivemos a oportunidade de analisar detalhadamente estes aspectos no capítulo II, limitamo-nos aqui apenas a assinalar os elementos discursivos e retomar alguns outros aspectos à medida que se façam necessários.

A estrutura do périplo se viabiliza no cronotopo. Tempo e espaço, enquanto esferas lábeis, transmutam-se, respectiva e paradoxalmente, de canto e referências espaciais a silêncio e polifonia. O canto viabiliza-se na palavra articulada e escrita; esta última adquire maior importância e eficácia quando se transforma em elipse. Silêncio.

Em outras palavras, tempo e espaço se estruturam na narrativa como avatares da experiência. Ora, os estudiosos da obra clariciana são unânimes ao assinalar que sua poética, em essência, é uma grande metáfora do processo - dianóia, dialético - de aprendizagem ao qual se submete a escritora ao longo da gestação de cada narrativa.

Neste sentido, Uma aprendizagem, ao evidenciar o procedimento discursivo e apresentar a narrativa em um "in medias res" sem fechamento estrutural evidente, propõe-se como um romance paródico do próprio recurso da obra clariciana: seu périplo narrativo volta-se a si mesmo, em um jogo de espelhos - quiasma - que distorce. A ironia reside em que o eterno retorno sobre si mesmo implica em uma re-leitura diversa a cada movimento de retrocesso ou de avanço, devido à experiência adquirida, não apenas com a leitura de sua obra, mas de toda uma tradição na qual ela possa ser inserida. 
Mas, se no romance clariciano se evidencia o uso de uma técnica romancesca herdada da epopéia e levada ao seu limite, El silencio de las sirenas corrobora a teoria bakhtiniana da origem híbrida do romance, uma vez que se vale de um recurso da tragédia para compor o seu procedimento narrativo.

Como já vimos no capítulo III, a narrativa de García Morales se instrumentaliza com um certo "ditame oracular" que insinua o desenlace do romance. Esta previsão, presente nos primeiros parágrafos, resgata no leitor aquela necessidade catártica do espectador da tragédia de outrora que, agora transmutada em curiosidade, leva-o a buscar o como e o porquê da fatalidade descrita. São estes os elementos que abrem a odisséia urdida pela narradora que, à medida que avança, revela-se como avatar da experiência de leitura de várias linguagens que a compõem e que, dialeticamente, mimetizam as obras representadas: cartas, fotografias, quadros etc.

A paródia posiciona o cronotopo, ironicamente, num alucinante jogo de espelhos, numa instigante dinâmica de reversibilidade. A ação narrativa se propõe como palavra narrada, desde o princípio de que ela acontece onde não está; em outras palavras, ela se viabiliza na intertextualidade, cobrando do leitor uma função ativa, do contrário, sua estaticidade condena ao fracasso a concretização da dinâmica do périplo.

Portanto, na medida em que tempo e espaço se estruturam na dialogia estabelecida com outros cronotopos, é a partir de sua omissão, ou ainda, de seu congelamento em "benefício" do desenvolvimento da ação em outros tempos e espaços, que podemos ler / ouvir neste sobre e como a sua estridente essência silente. Portanto, é na elipse que o cronotopo se significa.

Em que medida a viagem constitui-se em um tema ou apenas em um elemento estruturador para ambos romances? Esta pergunta, latente ao longo de nossa análise, 
corre o risco de não ter sido respondida com a clareza necessária; acerquemo-nos, então, ainda mais a nossa leitura contrastiva de suas estruturas.

Bakhtin, Benjamin, Lukács e Goldman quando apresentam o herói moderno o fazem sob a figura de um individuo em choque com o mundo. Bakhtin, entretanto, evidencia o papel do escritor neste jogo de poder estruturador do universo / mundo narrativo.

El carácter cronotópico de un texto (resultante de la dinámica social) proviene del autor que es un individuo dentro del cual se libra la lucha entre tradición y ruptura de convenciones culturales. Su visión constituye el punto de vista de un hombre constructor, debido a que es capaz de captar un espacio, una zona dada junto con su contenido histórico / cultural, de modo que se obtenga de ella una especie de unidad histórico / geográfica en la que se subyace también una imagen artística de héroe: el personaje con su atuendo sociocultural, dado sobre todo por su propio lenguaje que es el recipiente y el vehículo de la cultura. (BERISTÁIN: 1997, 118)

Portanto, se o autor trava uma luta entre tradição e ruptura de convenções culturais, esta pugna se refletirá na forma do indivíduo / personagem em choque com seu mundo.

Esta tensão se fará presente neste dois romances que estudamos a partir de dois pólos. As personagens parecem bordejar entre a inércia e a ação. Se tomarmos estas extremidades como relativizadoras do conflito que rege cada odisséia, notamos que, se já no início encontram-se em total desequilíbrio, pendendo mais para a imobilidade, com o avançar da narrativa, esse equilíbrio se recupera em direção à ação e este movimento se dá através da dialogia.

Em um primeiro nível, a dialogia de Lóri parte de um sôfrego monólogo interior para se estruturar em cartas e diálogos com Ulisses. A de Elsa, de uma ausência inanimada, para um fantasmagal ânimo cujos diálogos e cartas estão em busca de um destinatário que as decifre. Mas, “decifra-me, meu amor, ou serei obrigada a devorar", 
são palavras de Lóri, quem as cumpre em constante ato antropofágico; Elsa, à deriva em seu controvertido périplo íntimo, abandona-nos diante das manobras de Maria e dos ritos de Matilde.

Em outro nível, o foco narrativo sob a perspectiva de Lóri apresenta uma rebeldia ativa na formulação de seu discurso em ritmo afinado com a intertextualidade que a re-significa. Assim seus estados de ânimo se fazem vislumbrar em uma série de pinturas que vão do neoclássico ao abstracionismo; o seu ritmo poético cronotópico é apocalíptico, existencialista e se renova na comunhão com a natureza e com o divino da poesia a la Heine. A imobilidade de Elsa, por sua vez, representada pelo congelamento fotográfico e o ponto de vista da narradora Maria, serve de metáfora perfeita para o seu caráter de personagem subversiva. Assim, envolta a sombras de pinturas de Goya consegue sobrepujar a "luminiscênica" do que não existe no simbólico gesto do auto refletir-se infinito de Goethe; a sua cadência discursiva se trama em uma arritmia crítica e irônica ao "prosaísmo" que visita, mas não deixa de estar em total comunhão com a sua natureza mítica.

Chegamos a uma questão intrínseca às duas personagens, a natureza. Há pouco comentávamos que a linguagem poética desenvolvida pela dialogia de $U A$ comunga com o divino expresso pela poesia de Heine. Este poeta de língua alemã reflete em sua obra influxos constantes e essenciais à vida humana: o amor e a morte. Mas, é Rilke quem aperfeiçoa as diretrizes heniana:

Amor y Muerte, siempre unidos, que bajo la capacidad creativa del poeta se diversifican en una interacción múltiple hacia lo femenino, la naturaleza, lo divino y lo demoníaco, la soledad, la metamorfosis individual y, cómo no, el arrebato misterioso de los sentimientos.

Es sin embargo el amor, entendido como vía de unión con espíritus y cuerpos, quién se enseñorea de la obra del poeta de Praga a cada paso, desde sus primerizas "Canciones" hasta sus definitivos "Sonetos a Orfeo". (GONZÁLEZ: 1995, 15-6) 
São estas as características da poesia rilkiana que pensamos permear também a natureza da prosa poética clariciana: uma conjunção dos elementos da odisséia de aprendizagem para a elevação mística do encontro amoroso "donde la energía erótica se sublima premeditadamente en alturas místicas.”(Idem: 16). Em outras palavras, o final da trajetória de Lóri revela a superação do conflito indivíduo x mundo em uma perfeita comunhão:

[...] Era um saber tão vasto e tranquilo que "eu não sou eu", sentia ela. E era também o mínimo, pois tratava-se, ao mesmo tempo, de um macrocosmo e de um microcosmo. Eu me sei assim como a larva se transmuta em crisálida: esta é minha vida entre vegetal e animal. Ela era tão complexa como o Deus: só que Este tinha uma ignorância sábia e perfeita que $\mathrm{O}$ guiava e ao Universo. Saber-se a si mesma era sobrenatural. Mas o Deus era natural. (p. 147)

A comunhão de Elsa com a natureza, por outro lado, demonstra uma concepção própria do conflito apresentado, projetando-se em sua condição mítica. Após todos os quadros e fotos apresentados ao longo da narrativa e seus desmantelamentos em benefício próprio, Elsa escolhe e monta a sua própria tela, é neste momento que ela se volta para o insólito espaço que tanto evitara.

Elsa se quedó, pero yo sentí su ausencia como si hubiera abandonado este pueblo, Nos esquivaba tanto a Matilde como a mí. Se obstinaba en permanecer sola en su casa o entregada a paseos interminables por las montañas. Alguna vez, al mirarla, percibí una clara transparencia, como si ya no hubiera nadie dentro de ella. No volvió a mencionar el nombre de Agustín Valdés. En ningún momento aludió a su amor ni a aquella historia singular que ahora quedaba a medio desenterrar. (p. 163 - negritos nossos)

Antes de concluir a sua trajetória, Elsa apresenta em sua própria imagem primeiramente com uma beleza "sobrenatural" - a desintegração de seu ser no vazio de sentido que alcançara a sua existência. Neste contexto, podemos considerar que as 
palavras do narrador de $U A$ vêm ao nosso propósito: "Ela se sentiu perdendo todo o peso do corpo como uma figura de Chagal" (p. 147).

Enquanto Lóri, num movimento de integração com o cosmos, recupera a sua essência etérea e cumpre com o seu desígnio - "Um dia será o mundo com sua impersonalidade soberba versus a minha extrema individualidade de pessoa mas seremos um só" (p.73) - encontrando-se na plenitude de sua existência, Elsa se esvazia de significado, para recuperá-lo em seu último ato subversivo, não na pequena morte primaveril, mas na grande morte invernal.

As odisséias de ambas personagens coincidem como estrutura que gera a formação de suas identidades, ainda que o que as impulsiona seja o sentimento amoroso, a forma diversa como cada qual lê, interpreta e vivencia esse sentimento revela os valores sociais que promovem o "choque" com as convenções culturais e literárias. O périplo, portanto, pode ser lido, interpretado e vivenciado como um tema, o eterno retorno à tradição, resignificando-o, agora "repleto de tempo e espaço", como o nostos da polifonia feminina ao seu lugar de direito, a narrativa literária.

\section{2 - Um mito, diversas releituras}

Walter Benjamin, com relação à linguagem poética e o mito, argutamente afirma que:

Los logros más pobres del arte se refieren precisamente al sentimiento inmediato de la vida, en tanto, los más espectaculares, desde el punto de vista de su veracidad, tienen que ver con una esfera emparentada con el mito: lo poetizado. Dícese que en general, la vida es lo poetizado de los poemas, no obstante, cuanto más inacabada intenta el poeta transferir la unidad vital en unidad artística, más se pone en evidencia como ignorante y chapucero. $(1991,93)$ 
Esta reflexão do estudioso alemão, ao nosso entender e a partir do até agora exposto, vai ao encontro da formulação mito-poética narrativa aqui proposta. Lóri e Elsa além de serem personagens "prismáticas" e de refletirem a "melancolia da influência" como enigma interpretativo, têm em comum uma postura avant la lettre diante do prosaísmo que impõe certa ordem, certo ritmo e uma "escritura desatada" peculiar a suas respectivas mimesis mítico-poéticas.

Elsa tem plena consciência da situação trágica na qual se encontra. Tanto que é capaz de "assistir" o seu teatro e a reação do público (Maria e Matilde) ao mesmo tempo e, ironicamente, impor a sua visão contextualizada - conforme vimos “iqué prosaica eres!”. Este simulacro chega a se transformar em sua realidade vital. Neste sentido, Elsa se irmana a personagens emblemáticas como dom Quixote e Emma Bovary, a ponto de desenvolver o "quixotismo" ou, em melhor sincronia com a sua trama, o "bovarismo".

Suas atitudes, portanto, longe de serem um mero reflexo da vida - do "sentido imediato da vida" -, aproximam-se da mimesis transversalmente na meta-ficção autoconsciente e autoreflexiva, uma vez que expõe de forma deliberada a criação de sua "persona", referindo-se a si mesma como avatar de personagens de outras obras. Apenas "aproxima-se" porque não diz, ou ainda, não se caracteriza conscientemente também como ficção. Elsa não se sabe ficção - embora nós, leitores, saibamos de sua situação -; pelo contrário, ela lê a ficção como se fosse realidade, ou ainda, como um oráculo de sua realidade.

Este procedimento narrativo, de não ocultar, melhor dito, de chamar a atenção para a construção da personagem e, conseqüentemente, da trama romancesca, revela ao leitor a sua condição de ilusão recriada e a qual simulacro literário ela se reporta.

Sob este e outros aspectos dos quais nos ocuparemos, convém esclarecer a dialética que se apresenta nestes dois meta-romances. Por um lado, o meta-discurso, 
que representa a autoconsciência literária e pode ser traduzido por meta-literatura ou auto-referencialidade sob a perspectiva do discurso. Por outro lado, a meta-narração, que equivale à autoconsciência do narrador ou das personagens e pode ser entendido como a auto-referencialidade do narrador ou, ainda, das personagens no interior do relato. (GIL GONZÁLEZ: 2001, 53)

Se a estrutura narrativa de $U A$ se desenvolve mais no nível do meta-discurso como pudemos ver no item anterior - a de El silencio explora mais a característica meta-narrativa.

A leitura contrastiva, aqui proposta, viabiliza-se na medida em que ambos romances partem de um pressuposto em comum: a releitura do mito de Ulisses e Penélope, presente na Odisséia, através da recuperação da polifonia feminina. Ambas usam o monólogo interior como princípio estruturador do romance, ou seja, a "odisséia interior". Assim posto, se o romance clariciano pressupõe uma paródia do referido mito valendo-se mais de uma releitura meta-discursiva - o que a aproxima de outra obra emblemática da literatura universal, o Ulisses de Joyce ${ }^{81}$ - e o paródico de García Morales se inclina mais a uma perspectiva meta-narrativa - aproximando-se de $E l$ silencio de las sirenas, de Kafka -, esta prerrogativa apenas acentua a perspectiva metaficcional sob a qual se baseia esta análise.

\footnotetext{
${ }^{81}$ Seguimos aqui as ponderações de Lukács (1963, 18-9), quem comparando o Ulises, de Joyce com Carlota en Weimar, de Mann nos ilumina a comparação entre os dois romances que estamos tratando: "Si nos referimos al verdadero estilo de estas dos obras, no puede imaginarse antítesis más radical... Lo decisivo no es la diferencia de nivel espiritual, que llama la atención inmediatamente, sino el hecho de que en Joyce, el libre flujo de asociaciones no es una mera técnica estilística, sino la forma entera de la relación épica de situaciones y caracteres; estéticamente como principio de construcción de todo el Ulises, considero tal cosa la más importante en el aspecto artístico. En cambio, en Mann, el libre juego de las asociaciones es un simple recurso técnico utilizado para descubrir y poner de manifiesto una realidad que está muy por encima de las circunstancias inmediatas: la personalidad misma de Goethe y las complejas relaciones jerárquicamente clasificadas, que le ligan a su ambiente social y espiritual.
} 
Segundo Piero Boitani:

Ulises constituye lo que ciertos críticos contemporáneos llaman "discurso" de la civilización occidental, y ciertos historiadores "imaginario" "de larga duración"; en otras palabras, un arquetipo mítico que se desarrolla en la historia y la literatura, cual logos cultural constante. Parafraseando a Bernard Andreae, Ulises representa la "arqueología" de la imagen europea del hombre. En este sentido es completamente distinto de la figura hebrea de Jonás y de la oriental de Simbad, si bien guardan con él semejanzas significativas. Desde el principio, Odiseo se muestra abierto al futuro: a los travestimientos en que Homero es maestro consumado y a las transformaciones poéticas que su mito y su primer texto literario estimulan con sus excesos y sus vacíos evocadores.

Ulises es antiguo y moderno al mismo tiempo. Sus avatares constituyen un punto de observación ideal para medir las disonancias y consonancias entre la "alteridad" del pasado y la "modernidad" del presente; y ello tanto en términos históricos-culturales como en la dimensión "verdadera, humana, íntima y ferviente" de que habla Werther. $(1992,14)$

O primeiro movimento de reversão mítico-poética em comum a ambas tramas ${ }^{82}$, trata-se justamente da emblemática figura mítica de Ulisses. Além do fato de as duas personagens masculinas - Ulisses e Agustín - serem professores de filosofia ${ }^{83}$, são também ambos responsáveis pela odisséia das protagonistas.

Agustín Valdés - como a figura paterna de El Sur ou, como tivemos a oportunidade de analisar, a figura masculina de La casa de Bernarda Alba - é uma personagem que se faz presente a partir das referências feitas por Elsa e pela narradora, portanto, praticamente se presentifica pela elisão. Lembranças fugidias e palavras soltas - que passam pelo filtro da narradora, lembremos - são os elementos perfeitos para a idealização de sua imagem, que se transforma num reflexo da personagem Edward goethiana. Elsa - em função de Ulisses homérico - é a que realiza a sua odisséia através

\footnotetext{
${ }^{82}$ Não é nosso objetivo entrar na questão do gênero neste momento. Entretanto, retomando o já delineado no capítulo I, faremos uma ressalva no sentido de que a primeira reversão, ou antes, subversão seria justamente a do gênero, pois estamos tratando de dois romances que, ao retomarem a epopéia, propõem uma releitura de gêneros. Uma leitura similar foi feita por Beatriz Sarlo (1993) quando de sua análise do conto "El fin" de Borges; a estudiosa argentina sustenta que, ao colocar um "fim" ao poema de Hernández, Borges provoca uma outra interpretação ao gênero gauchesco.

${ }^{83}$ Lembremo-nos que Lukács vê o surgimento da filosofia exatamente na cisão provocada por Ulisses na Odisséia.
} 
das figuras literárias que lhe darão razão de ser. Mas, não é Agustín quem oferece a Elsa - e também a nós, leitores - o enigma de seu périplo? Não é ele quem lhe recomenda a leitura de Kafka e de Goethe?

Vale ressaltar uma vez mais que, não obstante Elsa se projetar em personagens e situações literárias e tratar de fazer o mesmo com a figura de Agustín, tanto Maria como Matilde tentam desconstruir essa imagem, na medida em que se empenham em trazê-la à "realidade". O leitor, entretanto, somente tem plena noção de quem é Agustín Valdés e de sua total ausência e, por conseguinte, indiferença com relação à trama quando o "vê" numa conversa telefônica com a narradora. É a partir deste fato que se tem a clara noção de quem é Agustín Valdés: aquele Ulisses que se resignou a seu mundo de "cadeias e cera" e resolveu se atrelar a efemeridades:

- La verdad es que nunca me ha parecido que Elsa estuviera sufriendo - me dijo en un momento de nuestro diálogo -. No puedo entenderlo. Y, además, no me siento destinatario de sus cartas. (p. 141)

- ¿Por qué no le escribo? Mira, me ha cogido en un momento muy conflictivo. Yo también estoy muy enredado en una historia de amor. Estoy viviendo un amour fou con una mujer casada. Es muy difícil. Estoy tan absorvido... (p. 142)

Este perfil que se nos apresenta tão drasticamente distante do "idealizado" por Elsa, aproxima-se deveras do Ulisses dantesco. Dante ao escrever sobre Ulisses na Divina Comédia se baseia em algumas suposições que compõem a hermenêutica que se erigiu a partir dessa figura homérica. Vamos a duas delas.

Na primeira, o lendário Ulisses não passaria de um impostor, de um grande mentiroso, um falacioso orador, conforme podemos ver na Eneida, de Virgílio e nas Metamorfoses, de Ovídio. Já a segunda tradição sustenta que o engano do supremo Ulisses é o do “intelecto", uma vez que já velho, ele se lança “mar adentro" em sua empreitada, defendendo que o verdadeiro conhecimento - experiência - não é o dos 
sentidos. Santo Agostinho, levando em consideração este pressuposto, argumenta que alguns filósofos-navegantes chegam ao porto da vita beata apenas se resistirem ao "horrendo monte" do excessivo desejo de glória e saber, cometido por Ulisses. Não é por acaso, portanto, que em Dante, Ulisses é o único condenado, de fato, ao inferno. (BOITANI: 1992)

Enquanto Agustín empreende a sua provável jornada sem resistir ao "horrendo monte", fugindo, assim, da verdadeira experiência, o Ulisses clariciano não apenas cumpre o seu périplo interior, mas, sobretudo, ao fazê-lo se redime de sua ancestralidade mítica, proporcionando à Lóri e ao leitor uma viagem - aprendizagem cujo porto de chegada será a vita beata. Diz Ulisses:

- [...] A verdade Lóri, é que no fundo andei toda a minha vida em busca da embriaguez da santidade. Nunca havia pensado que o que eu iria atingir era a santidade do corpo. (p. 148)

A vita beata, com efeito, é a finalidade de todas as filosofias e, ainda seguindo os argumentos de Agostinho de Hipona, poucos são os que conseguem alcançá-la.

En efecto, Agustín piensa que los maestros de la filosofía yerran, en grado mayor o menor, como puede comprobarse passim por sus obras; por ejemplo, en Confesiones, 7, 14, donde admite que los platónicos llegaron a conocer al Verbo, pero no la Redención, por causa de su soberbia.

En este diálogo, más que refutar cada teoría filosófica, va descalificar radicalmente a todos los maestros de filosofía, demostrando que son incapaces de enseñar lo que ellos pretenden. (LÓPEZ CABALLERO: 1975, 20-1)

A personagem masculina clariciana, portanto, não é idealizada como a de García Morales, ela antes cria um ideal de vida ou, ao menos, gera uma expectativa sobre seu ideal para Lóri, quem decide torná-lo também seu. 
Como professor de filosofia, Ulisses pertencente a uma classe média "acomodada" e, ironicamente, nunca saiu de seus limites urbanos, o bairro da Glória. Em contrapartida, não obstante Lóri ser uma mulher "errante", ela não lhe descreve os lugares, mas a sua sensação dos lugares, como se, neles estivesse fugindo de sua própria "tela negra". Em Berna ela trava contato com o seu silêncio e, em Paris, com sua essência negra ${ }^{84}$.

Um paralelo com a filosofia agostiniana nos esclarecerá as fases da aprendizagem de Lóri. Segundo o filósofo de Hipona, o sujeito cognoscente é a alma (o filósofo usa vários termos para expressar este conceito: animus, mens, spiritus etc), que, por sua vez, usa como intermediários da aprendizagem os sentidos. Assim, o "objeto" imprime no órgão sensorial uma forma ou similitudo de si mesmo. A alma adverte esta informação, ou conformação sensorial, e produz em si mesma outra forma, que Agostinho chama imago, e que é arquivada na memória.

A partir desta teoria desenvolvida em De Magistro (2003), podemos constar que Lóri inicia a sua aprendizagem - périplo interior ou da alma, sob o olhar atento do também argonauta Ulisses - em conformidade com a sua postura anterior perceptiva, mas que está em plena evolução: não é o Rio de Janeiro, a Floresta da Tijuca, o Posto 5, os alunos vestidos de vermelho que conhecemos, mas as sensações, a imago que Lóri projeta de seu íntimo, ou ainda, a transcedentalidade de suas transformações que se fazem presente, nas sensações que o "estar" nestes lugares transmitem ao "ser", durante a aprendizagem.

\footnotetext{
${ }^{84}$ Santo Agostinho demonstra a incapacidade de ensinar através das palavras ou ainda dos signos, que não seja através de Deus, em outras palavras, da experiência divina. Ora, a errância de Lóri, como podemos notar, também é feita através da essência da palavra e de sua representação sígnica. Segundo o mesmo raciocínio, Agustín (coincidência ou não, nome de Santo Agostinho em espanhol), desenvolve com Elsa apenas a primeira acepção de ensino (docere) agostiniano: a ampla e vulgar, no sentido de comunicar um conhecimento. (LÓPEZ CABALLERO: 1975, 25).
} 
Desta forma, as personagens femininas exercem muito mais a função "odisséica" que as masculinas, elas realizam a suas "penelopéias": entre o urdir, cada qual trama o seu périplo errante, em inebriante transgressão de imagens constituídas, elas cometem a primeira reversão do mito masculino da "grande viagem".

Esta odisséia - como tivemos a oportunidade de analisar nos capítulos anteriores -, tem um caráter de formação - bildung - de ambas as personagens. Esta formação, por sua vez, passa também por uma releitura de outros mitos, o de Penélope e o das Sereias.

Penélope, segundo Vernant e Detienne (1988) é a personagem, ou antes, o ser não divino mais astucioso da Odisséia; os estudiosos chegam a afirmar que a sua metis é superior a de Ulisses, porque a sua façanha de des-tecer, além de ser a primeira metáfora da escrita como trama, presente no urdir da epopéia homérica, é a que impõe à trama o ardil necessário para o grandioso reencontro com o "eterno marido".

Mas, este ardiloso perfil da personagem somente faz com que a sua personalidade seja ainda mais admirada como sinônimo de fidelidade, coragem e perseverança $^{85}$. É curioso constatar que, nas reminiscências da cultura popular, não há nenhum traço do lado negativo, que também pode estar presente neste aspecto de sua personalidade. À Penélope, portanto, relacionam-se os atos de "tecer" e "esperar", que estariam intimamente relacionados à fidelidade e à morte, como já tivemos a oportunidade de assinalar. É interessante observar que ambos verbos representam, justamente, a "ação" e a "inércia", atos estes inerentes às narrativas analisadas.

Uma vez que a figura de Penélope está intrinsecamente relacionada ao fazer narrativo, o qual classificamos como meta-discurso, no nível das personagens podemos

\footnotetext{
${ }^{85}$ Cabe esta pequena nota para aludir ao fato de que alguns escritores como Ovídio, Apolonio e Pausanias, fazem Penélope se casar com Telogonos, distrair-se com Mercúrio e, inclusive, ter filhos com este deus ou, ainda, entregar-se aos 108 pretendentes. Afinal de contas, como afirma Luis de Oteyza (1917, 117-123) usando palavras da "Carta aos Pisões" de Horácio, Homero dormiu ao conceber a personagem Penélope, pois nenhuma mulher esperaria mais de vinte anos por seu marido, colocando em perigo, inclusive, a vida de seu filho.
} 
relacioná-lo tanto ao urdir de Lóri como ao da narradora Maria. O de Lóri, desde o ponto de vista da inserção direta de seu discurso na narração, pois por diversas vezes, a terceira pessoa do discurso narrativo cede seu lugar à primeira pessoa - voz da personagem -, seja ela presente nas cartas que escreve a Ulisses ou nos pensamentos nos quais tenta "plagiar" a voz de Ulisses.

O meta-discurso da narradora María, por sua vez, processa-se em vários níveis. No primeiro, é a própria narradora quem expõe o procedimento narrativo, ao declarar que toma notas durante as sessões de hipnose para, depois, transformá-las em um relato completo. O segundo é o como ela se apropria do discurso de Elsa para, finalmente, montar o mosaico discursivo, composto por seus diálogos com Elsa, Matilde e Agustín.

A espera de Penélope, lembremo-nos, está envolta a um silêncio ao mesmo tempo em que o seu agir dissimula uma resignação quase servil ao amor dedicado ao esposo ausente há mais de vinte anos. A rainha de Ítaca como as Sereias, parece também estar enfeitiçada por Ulisses, ao extremo de este sentimento ser mais do que uma devoção, diríamos antes, tratar-se de uma obsessão.

E é este também o mal do qual padecem tanto Lóri como Elsa. Trata-se de um modo de viver o sentimento amoroso bastante peculiar, com um caminhar sôfrego sempre à margem da assombração do emudecimento ou, ainda, da busca da palavra ou linguagem perfeita para compor o idílio vivido. Enquanto Lóri se vê no umbral da perda do auto-controle devido à sua condição de "presa" do que ela pensa ser apenas um jogo amoroso, Elsa se posiciona como o vértice de uma problemática e provável relação amorosa, cuja solução e concretização, respectivamente, parecem estar além de suas forças. O idílio, então, não passa de uma idealização, de uma alienação diante do sentimento amoroso. 
Mas, se a obsessão de Lóri se transforma em auto-controle - e, como tivemos a oportunidade de analisar, esta transformação também se concretiza no cronotopo - a de Elsa perde o controle e contagia a Matilde e Maria, a narradora, é a esta última a quem cabe recuperar as "rédeas" das situação, trazendo Elsa e a trama a uma realidade mais plausível.

Ora, antes de qualquer dedução apressada que possamos ter, a obsessão em ambas narrativas também reflete a ânsia da busca da origem, que seria um dos pontos fundamentais da trama, revestida, entre outras formas, pela procura obstinada da "vida em si mesma", ou ainda, “do sentimento amoroso em si mesmo". Mas, a nudez da alma ou "o núcleo último da pessoa" concretiza-se, como vimos acima, através da "viagem".

Enquanto Lóri passa por sua própria bildung e a narrativa clariciana se constitui de uma plataforma da experiência da construção do próprio romance; Elsa é a plataforma da alteridade de personagens, a narrativa transverbera em sua metanarratividade a "persona", a máscara tragicômica em seu máximo sentido atua como avatar do teatro meta-ficcional.

Estas nossas duas personagens emblemáticas, portanto, caracterizam-se como dois extremos miméticos da constituição do indivíduo na construção e na desconstrução da estrutura narrativa. As duas se movimentam de um pólo a outro. Lóri da desconstrução à construção e, Elsa, o seu inverso. O ponto em comum, o êxtase, compreende a essência silente de cada una. Passemos, então, ao seu aspecto "sereia".

A Odisséia nos lança à sombra diante do "claro enigma" de não nos revelar "o que" se apreende das Sereias, proporcionado o surgimento de toda uma hermenêutica a elas relacionada, cuja interpretação não deixa de ser, muitas vezes, uma alegoria. Cabem aqui algumas outras indagações, além das já levantadas anteriormente. Para tanto fixemo-nos nas propostas por Piero Bointani: 
¿Quiénes son verdaderamente las Sirenas? ¿Unos seres oscuros del mundo subterráneo, como pretende Platón en el Cratilo? ¿O, como propone el mismo Platón en la República, con ejemplar sublimación e implícita auto-desconstrucción, unos seres celestiales que entonan la música de las esferas en el mundo futuro, y, por ende, para una edad posterior, “ángeles”? ¿Símbolos del deseo mundano y del placer de los sentidos, cortesanas y prostitutas, como creía el helenismo, o íconos del saber, del tipo de las doctae sirenes celebradas por Ovidio? ¿Y qué tendrían en mente los setenta traductores de la Biblia cuando, llegados a unos de los más tremendos lamentos de Job, le hicieron decir "seirenes" en lugar de "chacales", de manera que su grito contra Dios se convierte en "Hermano de las sirenas me he vuelto, compañero de los avestruces; mi piel se engangrena y se descama, mis huesos se queman de fiebre”? ¿Habrán relacionado acaso a las cantantes homéricas con el montón de huesos que las circunda? Hasta san Jerónimo, que en la Vulgata evita siempre el vocablo, hace pronunciar a un Isaías en manifiesta vena de exotismo sincrético hebraico-griego un oráculo sobre Babilonia según el cual la desgraciada ciudad será habitada por dragones, avestruces y "velludos" (sátiros, quizá), y sus palacios "de placer" por sirenas... (1992, 29-30)

Em fama, as Sereias ocupam o lugar oposto ao de Penélope. E, de fato, elas são a alteridade da rainha de Ítaca; em muitos relatos, comparam-nas a hetairas, o extremo oposto da exemplar esposa. Se Penélope representa o urdir da palavra escrita, as Sereias simbolizam o enredar do canto mortal, a sedução da palavra oral.

Lóri consegue alcançar uma harmonia nestas duas facetas, para tanto passa por um processo de aprendizagem e, a duras penas, consegue controlar seu instinto de sedução pelo canto e passa a desenvolver a sedução da palavra escrita por meio da escrita. Já Elsa, angustiada pela monstruosidade de seu espectro, está no limiar do canto, parece estar presa a prerrogativas que a impedem de "cantar" para Agustín, sua sedução se faz latente na escrita. Talvez, por esta razão, por optar usar a escrita ao canto ao dirigir-se a Valdés, somente consiga enredar a María e Matilde. 
São dois midraxim $^{86}$ de Kafka que tratam das Sereias. El silencio de las sirenas, que já tivemos a oportunidade de tratar, e um breve relato presente em uma carta de 1921. No primeiro, a "onisciência absoluta e esquizofrênica do narrador kafkiano" (BOITANI: 1992, 207) inova ao incluir o ponto de vista das Sereias:

Pero ellas, más hermosas que nunca, se estiraron y voltearon, dejaron ondear, libres al viento, sus abundosas cabelleras, y distendieron sobre las rocas sus dedos de larguísimas uñas. Ya no era más cuestión de seducir, sino que solamente querían -y tanto tiempo como fuese posible- atrapar todavía al vuelo algo del fulgor de ese par de grandes ojos que tenía Ulises.

As Sereias ficam "hipnotizadas" pelo olhar de Ulisses, é o homem quem hipnotiza, é ele quem se transforma em Sereia. Nos dois romances, Lóri e Elsa também estão "hipnotizadas", são as personagens masculinas, desde o mesmo ponto de vista kafkiano, as sedutoras e mortais Sereias. Mas no paradoxo presente neste midraxe kafkiano, se as sereias continuam sendo o que são, por um jogo da astúcia narrativa, as duas "contra-musas" modernas, Lóri e Elsa, superam este legado por diferentes vieses, como pudemos constatar.

O escritor tcheco, no segundo fragmento no qual se refere a estes terríveis seres e compara suas vozes às sedutoras vozes da noite, pondera que desta vez elas silenciam, não como arma mortífera, mas para lamentar-se de sua fealdade e esterilidade:

También las Sirenas han cantado así. Seríamos injustos con ellas si creyéramos que querían seducir. Sabíamos que tenían garras y seno estéril, y de esto se lamentaban en voz alta. No podían hacernos nada si sus lamentos eran tan bellos. (apud BOITANI: 1992, 207)

\footnotetext{
${ }^{86}$ Midraxim plural de midraxe (midrash - do hebraico שרדמי). A crítica - Benjamin, inclusive - chamanos a atenção para esta forma narrativa de tradição oral judaica como sendo a base da ironia kafkiana. Os pequenos contos kafkianos, portanto, muitas vezes recebem esta denominação. Ao citá-lo não estamos perdendo de vista a crítica clariciana voltada para o aspecto oral de sua obra
} 
O mito, então, ganha a "benevolência" de uma explicação racional. A explicação plausível para o seu silêncio residiria na surdez falaciosa do homem moderno. Ambas personagens, Lóri e Elsa, herdam estas vozes redimidas da tradição oral, em suas reversões kafkianas, para lhes dar novo alento. Como nos aporta Vernant, baseando-se em estudos de Detienne:

El mito, en su forma auténtica, aporta respuestas sin formular nunca explícitamente los problemas. La tragedia, cuando recoge las tradiciones míticas, las utiliza para plantear a través de ellas problemas que no admiten solución. $(1987,180)$

As questões que formulamos ao longo dos capítulos II e III, inerentes ao processo de análise, serviram-nos como suporte para distinguir alguns aspectos do nosso referencial teórico e confrontar alguns conceitos.

Estruturalmente, $U A$ leva às últimas conseqüências a proposta da epopéia homérica: a viagem e o in medias res. Ainda que o mesmo não aconteça com $E l$ silencio, uma vez que a sua estrutura, valendo-se também do périplo, tende mais para uma renovação romancesca do oráculo trágico, o romance de García Morales aporta um cronotopo circular. Conforme, mais uma vez nos esclarece Vernant:

Si se quiere evitar una visión del mito en el marco del logos que lo reemplazó, la explicación el texto debe estar en primer lugar atenta a todo cuanto deduce de la organización narrativa del relato. Los análisis de P. Walcot, y sobre todo el estudio de H. Schwabl, son en este plano concluyentes: han demostrado, por una parte, la existencia en el conjunto del texto de un modo de composición circular (ring composition) que da al relato su cohesión y permite discernir en él las articulaciones fundamentales, y, por otra, el recurso regular a paralelismos sintácticos que aseguran, en el encadenamiento de las diversas secuencias y en su rigurosa disposición de detalle, el equilibrio general de la narración y la unidad de su arquitectura. $(1987,181)$ 
Esta última parte conclusiva dos estudos de H. Schwabl parece escrita sob medida para a narrativa de El silencio. Os paralelismos não apenas sintáticos, mas também seqüenciais e a rigorosa disposição dos detalhes formam a unidade de sua arquitetura. A mesma afirmação podemos sustentar com relação à narrativa clariciana em seu contexto geral, principalmente se levarmos em consideração o seu aspecto autoreferencial ou, em outras palavras, narcísico.

Não podemos prescindir do fato de que Hesíodo, o grande mitólogo grego, ao selecionar os mitos e refundi-los, transformou-os em elementos de uma única mensagem com a qual objetivava comunicar o significado global e a sua rica complexidade; desta forma, o poeta grego colocou em sutil evidência todo o rigor de um sistema filosófico: um logos que já acompanhava a re-formulação do mito na linguagem escrita $^{87}$ (VERNANT: 1987, 182), o que reforça, uma vez mais, a "dialética do esclarecimento" proposta por Adorno e Horkheimer.

É pela viabilidade deste processo de elaboração sistemática - através do logos operada por Hesíodo e a comparação desta com as múltiplas versões fragmentárias dos mitos que, segundo Vernant (1987, 183-4), podem-se estabelecer três princípios que os regem.

Em primeiro lugar está o fato de pertencerem, apesar das divergências, a uma mesma tradição o que os torna de fácil assimilação e harmonização em seu conjunto. A segunda característica se refere ao fato de serem relatos extremamente sedutores ao mesmo tempo em que falam de coisas essenciais, sérias e afetam as verdades mais profundas. E, por fim, os relatos míticos coincidem em pôr em "cena", através de sua

\footnotetext{
${ }^{87}$ Sobre este aspecto o estudioso se detém, nas páginas anteriores desse estudo, a uma rigorosa análise à raiz do problema que aqui também já tivemos a oportunidade de aludir. Sobre esta questão apenas vamos nos deter um pouco mais nesta nota para citar o seguinte trecho que nos parece de extremo bom senso para resumir e revisar o que vimos propondo: "E. Benveniste tiene efectivamente razón cuando observa que Aristóteles, al tratar de definir el estatuto lógico de todos los predicados que se pueden afirmar del Ser, no hace otra cosa que reencontrar las categorías fundamentales de la lengua en la que piensa." (VERNANT: 1987, 172)
} 
forma narrativa, “' 'agentes' que llevan a cabo hazañas, de tal forma que la situación inicial se modifica en el curso del relato y no es de él lo que era al comienzo" (Idem: 184). Estes “agentes” - é no mínimo esclarecedor apontar - são as "potencias del más allá", que vivem em outro plano, diferente ao da "vida humana ordinaria". O que, pensamos, a meta-narrativa traduziu como o "complexo autoral".

Estes aspectos, portanto, contribuem para que, ainda hoje, estejam presentes nas narrativas literárias seja em sua forma estrutural ou na sua temática. Uma vez que a epopéia já os utilizava, por que o romance também não os utilizaria?

\section{3 - Os silêncios e as vozes da leitura}

Enquanto Kafka se propõe a cavilar a alteridade da "eterna esposa", dando voz às Sereias, Borges (1989-II, 275), em “Odisea, Libro vigésimo tercero”, ao nos remeter ao canto da Odisséia no qual Penélope, após pôr em dúvida a identidade de Ulisses, reconhece o marido e o acolhe em seu leito nupcial, qual astúcia kafkiana rompe com a estrutura da epopéia homérica e nos propõe uma capciosa dúvida, a da alteridade ulissiana:

Ya la espada de hierro ha ejecutado la debida labor de la venganza: ya los ásperos dardos y la lanza la sangre del perverso han prodigiado. A despecho de un dios y de sus mares a su reino y su reina ha vuelto Ulises, a despecho de un dios y de los grises vientos y del estrépito de Ares. Ya en el amor del compartido lecho duerme la clara reina sobre el pecho de su rey pero ¿dónde está aquel hombre que en los días y noches del destierro erraba por el mundo como un perro y decía que Nadie era su nombre? 
O poeta argentino, saindo da esfera mítica - cuja forma estética responde sem formular nunca explicitamente os problemas -, lança-nos a uma trágica questão e nos enreda - leitores de uma tradição - em um problema que não conjeturávamos existir. Desta forma, cobrando-nos tanto o reconhecimento de sua existência, vinculando-se à obra referida, como também uma solução. Entretanto, esta dialética não existe senão como possível proposta de re-leitura. Viabiliza-se na experiência leitora, na participação ativa do leitor.

Esta operação que, uma vez mais, comprova a transcendentalidade do mito conforme as aportações que vimos tecendo - pode, qual eco, processar-se num vazio retórico ou, ainda, levar-nos a uma especulação tão controvertida e paradoxal como a kafkiana, a clariciana ou, ainda, a de García Morales.

Mas esta especulação se torna possível na medida em que este vazio se faz matéria no silêncio expresso na narrativa. Clarice e Adelaida submetem o canto de suas sereias à lógica do absurdo: à expressão do indizível, através da idéia do eterno retorno, cujo nostos é o desarraigo na estrutura narrativa das entranhas do indivíduo, seja ele a personagem feminina, seja ele, em última instância, o leitor.

Por esta razão, a experiência como base estrutural do cronotopo se dilui dialogicamente e se significa menos no que diz, e mais no que se projeta. E esta projeção inclui o leitor.

Assim, faz-se necessário construir uma lógica para que não passe a se representar uma imagem hipnotizada ou infernal, para que esta experiência se signifique, pelo menos, como a recuperação do mythos no logos.

Júlio B. Gomes em seu artigo "A palavra e o silêncio: o exoterismo em Clarice Lispector" assevera que: 
A maior ou menor capacidade de nomear o mundo define a maior ou menor perplexidade e terror em relação ao mesmo. No momento em que as coisas são nomeadas, rotuladas, deixam de ser assustadoras e passam a fazer parte do conhecido, do familiar. $\mathrm{O}$ processo de apreensão do mundo pela palavra, contudo, tende a revestir a realidade com uma opacidade embrutecedora que anestesia a nossa percepção e nos induz a ver como óbvio, banal, algo que em sua essência é mágico e misterioso. Dentro desse universo, onde a palavra deixou de habitar o mais íntimo da alma humana e perdeu, para usar uma expressão de Guimarães Rosa, a sua condição de "porta para o infinito", a literatura constitui um elemento de transcendência, um meio de quebrar os condicionamentos limitadores do cotidiano e (re)instaurar o sentido "místico" das coisas. [...] Estabelece-se, assim, uma oposição entre a palavra que está por tocar algo que não "entende", e a palavra que já rotulou, "entendeu", e remete o "entendido" para o prosaico e o esquecimento. ( $\mathrm{s} / \mathrm{d}, 01)$

O mundo clariciano das palavras, no entanto, é o da experimentação, o do "esgarçamento da linguagem". E, na medida em que este procedimento também constrói o indivíduo, transforma-se no sinônimo da personagem e do leitor. Em palavras de Clarice:

[...]. Eu tenho à medida que designo - e este é o esplendor de se ter uma linguagem. Mas eu tenho muito mais à medida que não consigo designar. A realidade é a matéria-prima, a linguagem é o modo como vou buscá-la - e como não acho. Mas é do buscar e não achar que nasce o que eu não conhecia, e que instantaneamente reconheço. A linguagem é o meu esforço humano. Por destino tenho que ir buscar e por destino volto com as mãos vazias. Mas volto com o indizível. O indizível só me poderá ser dado através do fracasso da minha linguagem.

[...]. Só quando falha a construção, é que obtenho o que ela não conseguiu. $(1990,180)$

É o choque do autor com o seu fazer literário que estrutura o da personagem com o seu mundo. E esta operação se faz visível no ritmo narrativo; tempo e espaço, em ritmo dinâmico e reversível, compõem o "sendo" tanto da experiência narrativa como também do indivíduo. 
Mas se o sendo de Lóri se traduz muitas vezes em imagens representativas de uma evolução iconográfica de seu estado de espírito; o de Elsa, por sua vez, far-se-á presente na fabulação apenas referida. O não dito, o apenas representado, seja através de referências imagéticas, seja no cerne da referencialidade, evidenciam ainda mais o recurso da "mascarada": o jogo de representação, a que ambas narrativas se referem, serve além de simulacro narrativo também e, sobretudo, de plataforma para os avatares das personagens.

Neste sentido, se as metáforas que remetem ao mito - esperar, urdir e seduzir presumem - nos dois romances, esclareçamos - a prerrogativa para a sua própria subversão, esta já "tradição da ruptura" salienta o caráter paródico e irônico da representação mimética.

O silêncio, tantas vezes referido textualmente - em El silencio já no título e na elisão do cronotopo, no clariciano tanto na estrutura como ao longo da narrativa transforma-se em uma quase condição para alcançar a expressão plena, no vazio necessário para aguçar a perspicácia do leitor o suficiente para que, ao menos, ele se incorpore ao mundo imaginário e, assim, dê vazão à concretização do pathos.

O paradoxo presente nos frontispícios de Augusto dos Anjos - Uma aprendizagem - e de Fernando Pessoa - El silencio - vêm ao encontro deste enredar narrativo e de encontro ao universo tangível do leitor: se a "mais alta expressão da dor" consiste "essencialmente na alegria" e se "Deus dá licença que o que não existe seja fortemente iluminado", como saber se a nossa alegria não passa de uma dor e, primeiramente, se não somos, também, apenas simulacros?

Não é por acaso que a estrutura subjetiva - de ambos romances - desloca-se e transforma o discurso e, principalmente, suas astuciosas formas elípticas em uma "realidade" palpável através de, pelo menos, três planos de técnica narrativa. 
A exteriorização do personagem / indivíduo conflitivo seria o primeiro destes planos. Enquanto Lóri é a própria representação do périplo romancesco, absorvendo os problemas estruturais e intrínsecos na sua expressão, Elsa absorve em sua problemática interior a outras realidades romancescas.

Desde este ponto de vista, a figuração do silêncio em $U A$ se conforma na própria representação discursiva ${ }^{88}$, a ponto de converter-se em sua máxima prerrogativa, mediada pelo foco narrativo que se centra em Lóri. Se, por um lado, esta "representação discursiva" transforma-se no signo da aprendizagem, por outro, faz-se traduzir na busca pela expressão do indizível; assim, a erupção discursiva do silêncio inicial, avança para o tema de uma, por assim dizer, ode à prática discursiva do silêncio, culminando com o final abrupto, outra forma elíptica convertida em metáfora representativa.

Já o universo literário das Sereias silentes kafkianas, que permeia o romance de García Morales, reforça no mosaico de referências - mise en abyme - a postura de Elsa, quem cede a voz para que outras a signifiquem, seja na inclusão de outros "modelos" literários, seja na adoção de outras prerrogativas discursivas como significado ao emudecimento. Desta maneira, através de sua voz, o discurso outro "parafraseado" por Maria e anteriormente calado desde a perspectiva masculina, adquire subjetiva e literariamente outro significado. Elsa, enfim, é a expressão da própria alteridade feminina.

O segundo plano de absorção técnica, então, está na forma como cada narrativa viabiliza o romance ao considerá-lo como a própria finalidade ou objetivo do fabular. Este plano é passível de se perceber nas referências meta-narrativas que aparecem ao longo de cada romance.

\footnotetext{
${ }^{88}$ Outra possibilidade interpretativa, encontramos nas reflexões de Piero Boitani $(1992,208)$ : "Pero ninguna de estas interpretaciones satisfacen plenamente. El silencio de la poesía y la metafísica es una imagen poderosa a la que el hombre moderno difícilmente puede resistir. Resulta igualmente sugerente, para 'quien sin esperanza vive el deseo', considerar la belleza de la literatura exclusivamente como un grito del hombre ante su radical esterilidad y su monstruoso 'ser de la muerte'."
} 
Assim, encontramos Lóri sondando este território, já no inicio:

- pois agora mansamente, embora de olhos secos, o coração estava molhado; ela saíra agora da voracidade de viver. Lembrou-se de escrever a Ulisses contando o que se passara,

mas nada passara dizível em palavras escritas ou faladas, era bom aquele sistema que Ulisses inventara: o que não soubesse ou não pudesse, escreveria e lhe daria o papel mudamente - mas dessa vez não havia sequer o que contar. (p. 15)

E, ao final quando Lóri declara: "Se você soubesse como é excitante eu te imitar" (153) e demonstra factualmente que o aprendizado da escrita romancesca se concretizou ao silenciar Ulisses, já que ele lhe havia dito: "Há um grande silêncio dentro de mim. E esse silêncio tem sido a fonte de minhas palavras. E do silêncio tem vindo o que é mais precioso que tudo: o próprio silêncio."(71) Nada mais sábio que deixar que o silêncio de ambos respeite o do leitor.

Já em El silencio, é Maria quem concatena as várias formas discursivas: “Al final tuvo su primera conversación con él. Y sobre ella había escrito Elsa en su cuaderno" (52) e quem procura discutir a verossimilhança: "La palabra 'realidad' inquietaba a Elsa. Ya lo había advertido en repetidas ocasiones. Tenía el problema de producirle una desagradable desazón”. (77) E a única ação de Elsa que a aproxima da realidade é a escrita: "De momento la escritura era la única forma posible de acercamiento a ti." (82) ou ainda sob a visão de María: "Esa peculiar forma de existencia que era para ela la escritura, acababa de ser destruida. Al escribirle, existía para él. Y también era en la escritura donde únicamente se iba realizando su amor."(152) E, finalmente, quando Maria encerra o romance com esta metáfora lapidar da sua prática metanarrativa: “Cerré el sobre y lo envié a su destinatario, sin añadir nada más. Temí que la muerte de Elsa no le impresionara como en los sueños en que ella tanto le había amado." (168), num temor interrogativo que o relato dirige ao leitor: na captação experiência seríamos também tão intocáveis quanto Agustín e Ulisses? 
E, por último, o plano de absorção que consiste na inserção do relato em um espaço de expressiva carga simbólica. Do Rio de Janeiro de Lóri, as referências ao mar e à Floresta da Tijuca são fundamentais; enquanto que a própria representação históricoespacial de Las Alpujaras, constituem o ambiente simbólico perfeito para Elsa.

Da incômoda e nauseante sensação que causam os peixes frescos, quase mortos, no Posto 5, à perfeita comunhão marinha com os banhos, realizados ritualmente na primeira hora da manhã ${ }^{89}$, há a aceitação da truculenta violência que nós animais racionais, mas animais, temos que "civilizadamente" respeitar, como diz Ulisses:

- Não sei se no restaurante da Floresta da Tijuca tem galinha ao molho pardo, bem pardo por causa do sangue espesso que eles lá sabem preparar. Quando penso no gosto voraz com que comemos o sangue alheio, dou-me conta da nossa truculência, disse Ulisses.

- E também gosto, disse Lóri a meia voz. Logo eu que seria incapaz de matar uma galinha, tanto gosto delas vivas, mexendo o pescoço feio e procurando minhocas. Não era melhor, quando formos lá, comer outra coisa? Perguntou meio a meio.

- Claro que devemos comê-la, é preciso não esquecer e respeitar a violência que temos. As pequenas violências nos salvam das grandes. Quem sabe, se não comêssemos os bichos, comeríamos gente com o seu sangue. Nossa vida é truculenta, Loreley: nasce-se com sangue e com sangue corta-se para sempre a possibilidade de união perfeita: o cordão umbilical. E muitos são os que morrem com sangue derramado por dentro ou por fora. É preciso acreditar no sangue como parte importante da vida. A truculência é amor também. (97-8)

O Rio de Janeiro se constitui como ambiente ideal que media o encontro de Lóri com sua nefasta essência. Através dele o mítico nostos, à suas origens esquecidas e relacionadas à terra mãe se viabiliza pelo catarse proporcionada por rituais de contato com thanatos, para superar a "pequena morte" estridentemente silenciosa e "necessária a cada dia".

\footnotetext{
${ }^{89}$ Horário em que os barcos saem para a realizar a pesca.
} 
São as emblemáticas e históricas alturas de Las Alpujarras que constituem, além do "último refúgio" mouro, o refúgio narrativo ideal cuja simbologia por si só carrega o peso do silêncio figurativo capaz, dialeticamente, de se elidir e de estar arrebatadoramente presente ao longo do relato. É este ambiente o sinônimo da essência silenciosa que a narrativa trata de dar voz, transformando-se em avatar de outros cenários e personagens mudos. Neste sentido, Las Alpujaras se irmanam com Elsa, calando os discursos que se impõem, revelam-se e, ao final, encontram-se com uma única essência.

Toda e qualquer viagem tem como objetivo a busca do conhecimento ou a satisfação de um desejo oculto, como nos explica Jung "el viajar es una imagen de la aspiración, del deseo nunca saciado que en ninguna parte encuentra su objeto"(JUNG: 1962, 128). No caso específico dos dois romances, o choque do indivíduo com o mundo impulsiona as personagens a empreenderem através de ficções, hipóteses, mitos da tradição um périplo que, mais do que pôr em questão a ideologia que rege a mimesis literária, busca recuperar outro percurso através de uma leitura prismática da própria experiência suscitada.

Esta pugna deflagrada entre o indivíduo e o mundo cindido pela alteridade mimética, é curioso constatar, nada mais revela que através do des-tecer da forma de construção - bildung e meta-ficção - os silêncio esquecidos e não questionados e, ainda, revelam mais do que as palavras sedimentadas e incansavelmente interpretadas: o silêncio necessário que de forma irônica se impõe respeitosamente. 
[...] Odiseo no oye ni ve. Lo que el relato sugiere en última instancia - prefigurando al mismo tiempo la muerte de la poesía y del ser, y el canto al lado inhumano del hombre - es el Silencio de la Interpretación. Si es verdad que la poesía puede dejar indiferente al ser humano y ser matada, no es menos cierto que la lectura, la crítica y la exégesis, que prolongan la vida de la poesía, tienen unos límites intrínsecos. Llega un momento en el que éstas, ante el mal que hace la Palabra con sus Enigmas, deben callar finalmente. (BOITANI: 1992, 210) 


\section{CONCLUSÃO}

La imaginación es el nombre del conocimiento en literatura y en arte [...] La novela ni muestra ni demuestra al mundo, sino que añade algo al mundo. Crea complementos verbales del mundo. El tiempo de la escritura es finito. Pero el tiempo de la lectura es infinito.

Geografía de la novela, Carlos Fuentes

La mayoría ignora lo que tiene nombre, la mayoría cree en la existencia de todo lo que tiene nombre.

Malos pensamientos, P. Valéry

Canta al ángel el mundo, no lo indecible...

Elegías de Duino, Rilke

O percurso que realizamos nos capítulos precedentes, pelo interior das estruturas narrativas de cada romance e através delas, levou-nos a reconhecer, em algumas imagens literárias e filosóficas que nelas se produziram, as marcas de um modelo de racionalidade mítica - o logos do mythos - que transita a partir do choque indivíduo versus mundo. Imagens estas que, dentro e fora de suas idiossincrasias, convergem e divergem em suas facetas múltiplas.

Não obstante, a Odisséia, referencial clássico aludido em ambos romances e por esta razão aqui utilizado, caracterizar-se por um "universo fechado", alguns fatores contribuem para que ainda hoje, depois de séculos que se converteram em milênios, a epopéia homérica permaneça como um modelo literário paradigmático por excelência. 
Um deles é a forma como nela se relata o mito. Um outro, pelo que pudemos observar, deve-se ao fato de que o universo fechado ali representado já apresenta, no cerne de sua estrutura, o momento de cisão da sua totalidade; em outras palavras, a sua estrutura já contempla a figuração de um mundo em crise, a desintegração das estruturas míticas, a subversão da personagem / ouvinte que toma a palavra para narrar a sua própria experiência.

Seja intencional ou não, a tradição literária ocidental submete estes parâmetros a freqüentes leituras / narrações também subversivas. A lista de escritores que a contempla é enorme, diríamos infindável. Alguns ilustres nomes são Heine, Kafka, Dante. Aos quais acrescentamos Lispector e García Morales.

Conforme estudiosos como Adorno, Horkheimer, Lukács e Benjamin, o universo cindido que se faz visível já na estrutura da epopéia engendra a essência do romance na instauração mimetizada do conflito do indivíduo versus mundo. Esta estrutura se configura na representação de um espaço no qual se percebe o simulacro narrativo: a esfera mítica de "malabarismos" com as personagens passa a ser ocupada pelo narrador.

Por um outro lado, Bakhtin, não negando tais raízes, pondera que: "O romance, tomado como um conjunto, caracteriza-se como um fenômeno pluriestilístico, plurilíngüe e plurivocal”.(BAKHTIN: 1998, 73)

O "eterno retorno" ao fabular de uma "viagem mítica" como estrutura narrativa e como tema, se a um tempo nos leva a recuperar as suas origens literárias, a um outro, não deixa de problematizar a organização de sua estrutura e a passagem da oralidade à escrita, tal como assevera Vernant (1987: 172) "La organización del discurso escrito va acompañada de un análisis más riguroso y una ordenación más estricta de la materia conceptual", uma vez que na literatura escrita se instaura "este tipo de discurso en el que 
el logos no es ya únicamente la palabra, en el que ha adquirido valor de racionalidad demostrativa y se opone, en este plano, tanto en la forma como en el fondo, a la palabra del mythos" (IDEM, 173)

A partir destes pressupostos, ao comparar dois romances que revisam o fabular mítico homérico desde viéses múltiplos, procuramos durante nossa análise ter o cuidado de expor os problemas de transposição da fabulação "em comum" - o mito de Ulisses, de Penélope e das Sereias - tanto no nível da estrutura romancesca como também de seu $\log$ os.

Neste trabalho intenso de análise, leituras e revisões teóricas, pudemos encontrar muitas simetrias, mas, sobretudo, assimetrias entre ambas obras. Pensamos que este último fator, em especial, veio a enriquecer sobejamente o nosso estudo e a reiterar o pressuposto comum da intertextualidade e subversão mítica.

Sob este aspecto, foi-nos especialmente instigante constatar que a dialogicidade latente entre os dois romances, na mesma medida, deflagra justa e ironicamente respeitadas as idiossincrasias próprias de cada autora e sistema literário - uma revisão das vozes discursivas visitadas e da hermenêutica a partir delas estabelecida.

E é a partir desta dissimulada revisão que ambas narrativas, dialeticamente, aproximam-se na intertextualidade que estabelecem entre si e, concomitantemente, distanciam-se nas soluções que apresentam ao subverter as antigas estruturas e a tradição fabular mítica.

Essa dupla operação subversiva suscitada por ambos romances, entretanto, não objetiva mostrar o fim da linguagem mítica do logos clássico, tampouco intenciona desejar, ou ainda, instaurar o fim de seus fundamentos; antes, e sobretudo, prepondera pôr em discussão a crise entre o indivíduo e o mundo, levando em consideração o poder estabelecido e legitimado a partir de sua instauração, mediante uma nova interpretação 
representativa e / ou figurativa do real. Em outras palavras, ambos romances procuram estabelecer, através de um olhar outro da experiência, novas formulações de sentido para a tradição.

Neste sentido, a prática meta-ficcional - que podemos vislumbrar em ambos romances - reforça outra característica intrínseca ao gênero romancesco apontada por Bakhtin: a de sua natureza de incompletude.

A epifania, de Uma aprendizagem, e o enigma, de El silencio, outrossim, constituem os possíveis desenlaces das narrativas aqui analisadas e, também, os desta conclusão. Lispector e García Morales a cada passo de suas respectivas narrativas nos acrescentam em seus périplos e, dicotomicamente, redobram a nossa perplexidade pelo nosso re-conhecimento ou assombro diante do insólito que nos rodeia.

Se as assimetrias entre as narrativas são evidentes, principalmente na tessitura que Lóri e Elsa entoam - condenando, respectivamente, esta à desilusão amorosa e à morte e, aquela, à realização amorosa e à vida -, estas características peculiares reforçam, uma vez mais, a natureza do gênero romancesco em consonância com o universo que divisa.

Durante a leitura, leitores que somos, anulamos o tempo e nos introduzimos nas suas multiplas aspirais suscitadas, peculiares de cada universo e irmanadas pela origem em comum e, através deste ato, visitamos lugares insólitos ou "sinistros", tal o jogo mimético descrito por Borges no conto "El inmortal":

[...] El pensamiento más fugaz obedece a un dibujo invisible y puede coronar, o inaugurar, una forma secreta. Homero compuso la Odisea; postulado un plazo infinito, con infinitas circunstancias y cambios, lo imposible es no componer, siquiera una vez, la Odisea. Nadie es alguien, un solo hombre mortal es todos los hombres. Como Cornelio Agrippa, soy dios, soy héroe, soy filósofo, soy demonio y soy mundo, lo cual es una fatigosa manera de decir que no soy. $(1994,20)$ 
Assimetricamente, enquanto Elsa é o "ninguém" ulissiano para ser todas as personagens, Loreley se pergunta “quem sou eu?".

Neste impasse, leitores-personagem que somos, divisamo-nos ao longo deste exercício de análise, re-interpretação e re-leitura da tradição entre a epifania e o enigma: a re-leitura do mito pode nos levar aos nossos próprios abismos ou a um jocoso exercício ficcional, uma vez que, também somos factíveis de ser parodiados, afinal de contas, "Fácilmente aceptamos la realidad, acaso porque intuimos que nada es real" (BORGES: 1994: 18). E se é "só como romance que a epopéia se transforma em conto de fadas" (ADORNO et HORKHEIMER: 1985, 80) é como epopéia que o romance se transforma em uma fabulação mítica. 


\section{BIBLIOGRAFIA}

\section{1 - Obras de Adelaida García Morales}

GARCÍA MORALES, Adelaida (1993). El silencio de las sirenas. Barcelona:

Anagrama.

(1988). O silêncio das sereias. São Paulo: Brasiliense.

(1995). El Sur seguido de Bene. Barcelona: Anagrama.

(1987). O Sul e Bene. Trad. Augusto Massi. São Paulo:

Brasiliense.

(1990). La lógica del vampiro. Barcelona: Anagrama.

(1994). Las mujeres de Héctor. Barcelona: Anagrama.

(1995). La tía Águeda. Barcelona: Anagrama.

(1999). El secreto de Elisa. Madrid: Debate.

\section{2 - Estudos utilizados sobre García Morales}

ALCHAZIDU, ATHENA (2001). "Las nuevas voces femeninas en la narrativa española de la segunda mitad del siglo XX". Studia Minora Facultatis Philosophicae Universitatis Brunensis, L22, pp. 31-42.

BEISEL (ed. 1997). El arte de la memoria: Incursiones en la narrativa española contemporánea. Mannheim : Lehrstuhl Romanistik III, Universität.

CANAVAGGIO, Jean (dir. 1995). Historia de la Literatura Española. Tomo VI. Barcelona: Ariel.

CIPLIJAUSKAITÉ, Biruté (1988). "Intertextualidad y suberversión en El silencio de las sirenas, de Adelaida García Morales" in Revista Hispánica Moderna. Nueva York: Columbia University. Pp. 167-173.

COELHO, Marcelo. "Uma aparição na prosa espanhola". Ilustrada- Folha de São Paulo, 05/12/1987 - A39.

COSTA, Linda Santos. "Uma hesitação fatal" in Jornal Literário. Lisboa, 9/03/1989 p. 15. 
DIÁZ-DIOCARETZ, Myrian et ZAVALA, Iris M. (coords) (1999). Breve historia feminista de la literatura española (en lengua castellana). Col. Cultura y diferencia, pensamiento crítico, utópico. Barcelona: Anthropos.

GARRIDO, Elisa (1997). Historia de las mujeres en España. Madrid: Síntesis.

GONZÁLEZ, Juan Manuel (1995). La nieve en el espejo: crónicas literaria, 1989-1995 Madrid : Libertarias/Prodhufi.

GRACIA, Jordi (2000) (ed. Francisco Rico). Historia y crítica de la Literatura Española. Los nuevos nombres: 1975-2000. Barcelona: Crítica, vol. 9/1.

INSULA (1985). "Entrevista Adelaida García Morales: La soledad Gozosa”. No. 472, p.4.

MALAXECHEVERRÍA, Coro (1991). "Mito y realidad en la narrativa de García Morales." Letras Femeninas 17: 1-2: 43-49.

MILTON, Heloisa Costa. “A Conexão Cigana” in Leia, jan/1988, p. 29.

MONLEÓN, José B (1995). Del franquismo a la postmodernidad. Madrid: Akal.

MONTEJO GURRUCHAGA, Lucía et BARANDA LETURIO, Nieves (2002). Las Mujeres escritoras en la historia de la Literatura Española. Madrid: UNED Ediciones.

NICHOLS, Geraldine C. (1995). "Ni Una, ni "Grande", ni Liberada: la narrativa de mujer en la España demócrata”. In VV.AA.. Del franquismo a la posmodernidad. Madrid: ed. Akal.

OLEZA, Joan (1993). "La disyuntiva estética de la postmodernidad y el realismo". Compás de Letras. no. 3, pp. 113-126.

(1994). "Al filo del milenio: las posibilidades de un nuevo realismo". Diablotexto. no. 1, pp. 79-106.

(1996). "Un realismo postmoderno" in Insula, no. 589-90, pp. 39-42.

RODRÍGUEZ, Emma. “Adelaida García Morales regresa por partida doble”. El Mundo. Cuaderno de Cultura: 31/01/2001. 
STANLEY, Maureen Thobin (S/D). Una Visión Alterna Ante La Dicotomía Mítica: La Hibridación De Penélope y Las Sirenas en El Silencio de Las Sirenas de Garcia Morales. Umes/edu.

THOMPSON, Currie K.(1992). "El silencio de las sirenas: Adelaida García Morales' Revision of the Feminine 'Seescape'." Revista Hispánica Moderna : 298-309.

TOLEDO, Carmen. "Féminas, femeninas, feministas que escriben." In Leer, Junio 2000 pp. 28-31.

TORO, Alfonso de et INGENSCHAY, Dieter (eds.-1995). La novela española actual: Autores y tendencias. Kassel : Reichenberger.

ZAVALA, Iris (coord) (2000). Feminismo, cuerpo, escrituras. Santa Cruz de Tenerife: La Página Ediciones.

\section{1 - Obras de Clarece Lispector}

LISPECTOR, Clarice (1998). Uma aprendizagem ou Livro dos prazeres. Rio de Janeiro: Rocco.

(1984). A Descoberta do Mundo. Rio de Janeiro: Nova Fronteira. (1986). A Hora da Estrela. Rio de Janeiro: Nova Fronteira.

(1979). Laços de Família. Rio de Janeiro: J. Olympio.

(1982). O lustre. Rio de Janeiro: Nova Fronteira.

(1990). A paixão segundo GH. Rio de Janeiro: Francisco Alves.

(1997). ed. Crítica, Benedito Nunes, coord. A paixão segundo

G.H. São Paulo: ALLCA Scipionni Cultural.

(1980). Perto do Coração Selvagem. São Paulo: Círculo do

Livro.

\section{2 - Estudos utilizados sobre Lispector}

BEDASEE, Raimunda Maria da Silva (1998). Feminismo e violênica: representação da mulher na obra de Clarice Lispector e Marie-Claire Blais. Tese de doutorado - FFLCH/ USP.

BORELI, Olga (1981). Clarice Lispector. Esboço para um Possível Retrato. Rio de Janeiro: Nova Fronteira. 
BOSI, Alfredo (1997). História Concisa da Literatura Brasileira. São Paulo: Cultrix.

BRANCO, Lúcia Castello (1994). A traição de Penélope. São Paulo: Anablume.

CANDIDO, Antônio (1995). Vários Escritos - 3ª ed.. São Paulo: Duas cidades.

(1970) "No raiar de Clarice Lispector" in Vários Escritos.

São Paulo: Duas Cidades.

CARVALHO, Lucia Helena de Oliveira Vianna (1990). Mulher em cena: cenas de amor e morte na ficção brasileira. Tese de doutorado - FFLCH - USP.

(1991). “A literatura segundo

Lispector" in Revista tempo Brasileiro, vol. 104. Rio de Janeiro: Tempo Brasileiro.

(2003) "Tinta e Sangue: o diário

de Frida Khalo e os 'quadros de Clarice Lispector". Rev. Estud. Fem. ]

[online]. Jan./June 2003, vol.11, no.1 [cited 01 March 2006], p.71-87.

CIXOUX, Hélène. (1989). L'Heure de Clarice Lispector. Paris: des femmnes.

FARINHA, Rosa M. Fernandes Branco Brazao (1982). Creation de la vie: parallele entre Clarice Lispector et Jean Paul Sartre. Dissertação (mestrado)- FFLCH-USP.

FERREIRA, Teresa Cristina Monteiro. (1999). Eu sou uma pergunta: uma biografia de

Clarice Lispector. Rio de Janeiro: Rocco.

FRANCO Jr., Arnaldo (1993). O kitsch na obra de Clarice Lispector. Dissertação de mestrado - FFLCH - USP.

GOTLIB, Nadia Battella (1995). Clarice: uma vida que se conta. São Paulo: Ática.

GUIDIN, Márcia Lígia Roberto (1990). A estrela e o abismo. São Paulo, Dissertação de mestrado FFLCH/USP.

HOSIASSON, Laura Janina (1989). Ser secreto: imagenes de mujer en Clarice Lispector y Maria Luisa Bombal. Dissertação de mestrado - FFLCH.

KADOTA, Neiva Pitta (1997). A tessitura dissimulada: o social em Clarice Lispector. São Paulo: Estação Liberdade.

KAHN, Daniela Mercedes (2000). A via crucis do outro: aspectos da identidade e da alteridade na obra de Clarice Lispector. Dissertação de Mestrado: FFLCH-USP.

LINS, Álvaro (1963). Os mortos de sobrecasaca: ensaios e estudos (1940-1960). Rio 
de Janeiro: Civilização Brasileira.

LINS, Osman. O tempo em "Feliz aniversário". Lisboa, Colóquio Letras, no.

19/05/1974.

MAURA, Antonio (2003). El discurso narrativo de Clarice Lispector. Madrid: Universidad Complutense. Tesis doctoral.

NUNES, Benedito (1989). O drama da linguagem: Uma leitura de Clarice Lispector. São Paulo: Ática.

OLIVEIRA, Solange Ribeiro de.(1989) "Rumo à Eva do futuro: a mulher no romance de Clarice Lispector". Campinas: Revista REMATE DE MALES no. 9 - pp. 95-105.

PASOLD, Bernadete (1995). Themes and narrative techniques in the novels of Virginia Woolf and Clarice Lispector. Tese-doutorado. FFLCH -USP.

PINTO, Cristina Ferreira (1990). O bildungsroman feminino: quatro exemplos brasileiros. São Paulo: Perspectiva.

PONTIERI, Regina Lúcia.( 1999). Clarice Lispector: uma poética do olhar São Paulo: Ateliê editorial.

REGIS, Sônia. "O pensamento judaico em Clarice Lispector” in O Estado de São Paulo, 14 de maio de 1988.

ROSENBAUM, Yudith (1999). Metamorfoses do Mal: uma leitura de Clarice Lispector. São Paulo: Editora da Universidade de São Paulo: Fapesp.

SÁ, Olga de. (1979) A escritura de Clarice Lispector. Petrópolis: Vozes. . (1993). Clarice Lispector: a travessia do oposto. São Paulo: Annablume.

SANTOS, Roberto Corrêa dos(1991). "Discurso feminino, corpo, arte gestual, as margens recentes" in Revista tempo Brasileiro, vol. 104. Rio de Janeiro: Tempo Brasileiro.

(1987). Clarice Lispector. $-2^{\mathrm{a}}$ ed. São Paulo: Atual.

VARIN, Claire. (2002) Línguas de fogo: ensaio sobre Clarice Lispector. (Trad.

\section{Lúcia}

Peixoto Cherem). São Paulo: Limiar.

VIEIRA, Telma Maria (1998). Clarice Lispector: uma leitura instigante. São Paulo: Annablume. 
WALDMAN, Berta (1992). Clarice Lispector: A Paixão segundo C.L. São Paulo: Escuta.

(1992). Clarice Lispector: A Paixão segundo C.L. $2^{a}$. ed. rev.e aum. São Paulo: Escuta.

\section{3 - Outras obras de referência}

ALBALADEJO MAYORDOMO, Tomás (1986). Teoría de los mundos posibles y macroestructura narrativa. Alicante: Universidad de Alicante.

APULEIO (1963). O asno de ouro. São Paulo: Cultrix.

ABAD, NEBOT, Francisco (2002). Teoría de la novela y novela española. Madrid UNED.

ADORNO, Theodor W. (2003). Notas de Literatura I. São Paulo: Duas Cidades/ Ed. 34.

ADORNO, Theodor W. et HORKHEIMER, Max (1985). Dialética do Esclarecimento. Fragmentos filosóficos. Trad. Guido Antonio de Almeida. Rio de Janeiro: Jorge Zahar.

ALCHAZIDU, ATHENA (2001). "Las nuevas voces femeninas en la narrativa española de la segunda mitad del siglo XX". Studia Minora Facultatis Philosophicae Universitatis Brunensis, L22, pp. 31-42.

BAKHTIN, M (2004). Problemas de la poética de Dostoiévski. Madrid: FCE. (1998). Questões de literatura e de estética. 3. ed., Trad. Aurora Bernadini et al. São Paulo, Unesp.

BARRIOS AGUILERA, Manuel et SÁNCHEZ RAMOS, V (2001). Martirios y mentalidad martirial en Las Alpujarras. Granada: Universidad de Granada.

BARTHES, R (2005). El grado cero de la escritura. Trad. Nicolás Rosa. Madrid, siglo XXI.

BEISEL (ed. 1997). El arte de la memoria: Incursiones en la narrativa española contemporánea. Mannheim : Lehrstuhl Romanistik III, Universität.

BENJAMIN, Walter (1985). Magia e técnica, arte e política. Ensaios sobre literatura e história da Cultura. São Paulo: Brasiliense.

(1993) "Carta a Gershom Sholem” in Novos estudos. no. 35 
São Paulo: CEBRAP.

(1987). Obras Escolhidas I. São Paulo: Brasiliense.

(1991). "Franz Kafka". Para una crítica de la violencia y

otros ensayos (Iluminaciones IV). Madrid: Taurus pp. 135-161.

(1991). "O narrador"in Para una crítica de la violencia y

otros ensayos (Iluminaciones IV). Madrid: Taurus, pp.111-134 .

BERISTÁIN, Helena (1997). Diccionario de Retórica y Poética. México: Porrúa.

BITTENCOURT, Gilda org (1996). Literatura comparada : teoria e prática. Porto Alegre, Sagra - D.C. Luzzatto Editores.

BLANCHOT, Maurice (1994). El paso (no) más allá. Barcelona: Paidós.

BLANCO AGUINAGA, Carlos et alii (2000). Historia social de la literatura española (en lengua castellana). Madrid: Akal.

BLÁNQUEZ FRAILE, Agustín (1985). Diccionario Latino-Español/ EspañolLatino. Barcelona: Ramón Sopena.

BOBES NAVES, Carmen (1993). La novela. Madrid: Síntesis.

BOITANI, Piero (1992). La sombra e Ulises: Imágenes de un mito en la literatura occidental. Trad. Bernardo Moreno Carrillo. Barcelona: ed. Península.

BORGES, J. L. (1994). El aleph. Madrid: Círculo de lectores.

(1989). Obras Completas. Buenos Aires, Emecé.

BOSI, Alfredo (1997). História Concisa da Literatura Brasileira. São Paulo: Cultrix.

(2003). “ 'A máquina do Mundo' entre o símbolo e a alegoria” in

Céu, Inferno. São Paulo: Duas cidades / Ed. 34.

BRANCO, Lúcia Castello et BRANDÃO, Ruth Silviano (1989). A mulher escrita. Rio de Janeiro: Casa-Maria Editorial/ LTC - Livros Técnicos e Cietíficos.

BRANDÃO, Junito de Souza (2002). Mitologia Grega. - $13^{\mathrm{a}}$ ed. Petrópolis: Vozes.

CAMPBELL, Joseph. (1990) O poder do mito. Trad. Carlos Felipe Moisés. São Paulo:

Palas Athena.

CANAVAGGIO, Jean (dir. 1995). Historia de la Literatura Española. Tomo VI.

Barcelona: Ariel. 
CANDIDO, Antônio et alii (2000). A personagem de ficção. São Paulo: Perspectiva.

CARDOSO, Zélia de Almeida (1989). A literatura latina. Porto Alegre: Mercado Aberto.

CASTAGNINO, RAÚL H (1970). Tempo e expressão literária. Trad. Luiz Aparecido Caruso. São Paulo: Mestre Jou.

CHEVALIER, Jean et GHEERBRANT, Alain (1988). Dicionário de Símbolos. Coord. Carlos Sussekind, Rio de Janeiro, José Olympio.

COELHO NETO, J. Teixeira (1980). Semiótica. Informação e Comunicação. São Paulo: Perspectiva.

COSTA, Luis Inácio Oliveira (2005). Do Canto e do Silêncio das Sereias: Um ensaio à luz da Teoria da Narração de Walter Benjamin. Dissertação de Mestrado em Filosofia. PUC/SP.

COSTA, J. Almeida et MELO, A. Sampaio e (1996). Dicionário da Língua Portuguesa. Porto: Porto Ed.

COSTA VIEIRA, Maria Augusta da (1998), O dito pelo não dito: paradoxos de Dom Quixote. São Paulo: Edusp/FAPESP.

DAMIÃO, Carla Milani (2005). “ 'Os Tempos Felizes': A presença de elementos classicistas na estética lukacsiana”. In Revista Kriterion. Belo Horizonte, no. 112, dez/2005, pp. 311-320.

DIÁZ-DIOCARETZ, Myrian et ZAVALA, Iris M. (coords) (1999). Breve historia feminista de la literatura española (en lengua castellana). Col. Cultura y diferencia, pensamiento crítico, utópico. Barcelona: Anthropos.

DELEUZE, Gilles. (1974) Lógica do sentido. Trad. Luiz Roberto Salinas Fortes. São Paulo: Perspectiva.

DIEL, Paul (1991). O Simbolismo na Mitologia Grega. Trad. Roberto Cacuro e Marcos Martinho dos Santos. São Paulo: Attar.

DORSCH, Friedrich (2005). Diccionario de Psicología. Barcelona: Herder.

DURAND, Gilbert (1988). A imaginação simbólica. Trad. Eliane Fittipaldi Pereira. São

Paulo: Cultrix/Edusp. 
(1989). As estruturas antropológicas do imaginário. Trad. Hélder Godinho. Lisboa, Editorial Presença.

.(1981). Las estructuras antropológicas de lo imaginario. Trad.

Mauro Amiño. Madrid: Taurus.

ECO, Umberto (1986). Lector in fabula : a cooperação interpretativa nos textos narrativos. São Paulo: Perspectiva.

ELIADE, Mircea. (1972) Mito e Realidade. Trad. Pola Civelli. São Paulo: Perspectiva. - (1992) Mito do Eterno Retorno. Trad. José A. Ceschin. São

Paulo:

Mercuryo.

FERREIRA, Aurélio Buarque de Holanda (1986). Novo dicionário da língua portuguesa. Rio de Janiero: Nova Fronteira.

FOUCAULT, Michel (2004). A ordem do discurso. Trad. Laura F. A. Sampaio. São Paulo: Loyola.

FREUD, Sigmund (1989). "Três ensaios sobre a teoria da sexualidad" in Obras Completas. Trad. Jayme Salomão. Rio de Janeiro: Imago, vol VII.

FRYE, Northrop (1991). Anatomía de la crítica. Caracas: Monte Ávila.

FURLANI, Lúcia Maria Teixeira (1992). Fruto Proibido: Um olhar sobre a mulher. São Paulo: Pioneira.

GAGNEBIN, Jeanne Marie (1999). História e narração em W. Benjamin. São Paulo: Perspectiva.

GALÁN FONT, Eduardo (1986). Claves para la lectura de Tiempo de Silencio. Madrid: Ediciones Daimon.

GARCÍA, Carlos Javier (1994). Metanovela: Luis Goytisolo, Azorín, y Unamuno. Madrid-Gijón: Júcar.

GARCÍA LORCA, Federico (2000). La casa de Bernarda Alba. Madrid: Cátedra.

GARRIDO, Elisa (1997). Historia de las mujeres en España. Madrid: Síntesis.

GENETTE, Gérard (1989). Palimpsestos: La literatura en segundo grado. Madrid: Taurus. 
GIL GONZÁLEZ, Antonio Jesús (2001). Teoría y crítica de la metaficción en la novela española contemporánea: A propósito de Álvaro Cunqueiro y Gonzalo Torrente Ballester. Tesis de doctorado: Universidad de Salamanca.

GIRARD, René (1990). A violência e o sagrado. São Paulo: UNESP.

GOETHE, Johann Wolfgang (2005). Las Afinidades Electivas. Trad. e ed.. Manuel José González e Marisa Barreno. Madrid: Cátedra.

GONZÁLEZ, Juan Manuel (1995). La nieve en el espejo: crónicas literaria, 1989-1995 Madrid : Libertarias/Prodhufi.

GRACIA, Jordi (2000) (ed. Francisco Rico). Historia y crítica de la Literatura Española. Los nuevos nombres: 1975-2000. Barcelona: Crítica, vol. 9/1

HARTOG, François (1996). Mémoire d'Ulysse. Récits sur la frontière en Grèce ancienne. Paris: Gallimard.

(2004). Memória de Ulisses. Narrativas Sobre a Fronteira na Grécia Antiga. Belo Horizonte: UFMG.

HIPONA, Agostinho de (2003). El maestro o sobre el lenguaje y otros textos. Ed. e trad. Atilano Domínguez. Madrid: Trotta.

HORACIO (1992). Epistola a los Pisones. In Artes Poéticas.k (ed. Bilínguüe de Aníbal González) Madrid: Taurus.

HOMERO (1996). Odisséia. Trad. Manuel Odorico Mendes; ed. Antonio Rodrigues Medina $-2^{a}$ ed. São Paulo: ars Poética/Ed. da Universidade de São Paulo.

JAUSS, Hans Robert (1971). História da literatura como desafio à ciência literária. Literatura medieval e teoria dos gêneros. Trad. de Ferreira de Brito. Porto: Soares Martins.

et alii (1979). A literatura e o leitor. Trad. e coord. Luiz Costa Lima. Rio de Janeiro: Paz e Terra.

Passagens. (1993). A literatura como provocação. Trad. Tereza Cruz. Vega: (1994) A história da literatura como provocação à teoria

literária.

Trad. de Sérgio Tellarolli. São Paulo: Ática.

JOSEPHS, Allen et CABALLERO, Juan (2000). "Introducción" ao livro La Casa de Bernarda. Madrid: Cátedra.

JUNG, C. G. (1962). Símbolos de transformación. Buenos Aires: Paidós. 
(1987). Tipos psicológicos. 4.ed., Trad. Álvaro Cabra. Rio de Janeiro, Guanabara.

et al (s/d). O homem e seus símbolos. Trad. de Maria Lúcia Pinho. Rio de Janeiro, Nova Fronteira.

KAFKA, Franz (1983). Obras Completas. Barcelona: Editorial Teorema.

(1987). Obras Completas. Barcelona: Edicomunicación. Vol. IV. KRISTEVA, Julia (1984). O texto do romance. Belo Horizonte: Horizonte Universitário.

(1978). Semiótica. Madrid: Fundamentos.

( 2003). "Romeu e Julieta ou o amor fora-da-lei" in O olhar de Orfeu: os mitos literários do ocidente. Org. Bernadette Bricout; trad. Leila Oliveira Benoit. São Paulo: Cia das Letras - pp. 91-121.

LÓPEZ CABALLERO, Alberto (1975). Filosofía del lenguaje de San Agustín en su obra De Magistro. Tese de doutorado: Madrid: Facultad de Filosofía de la Universidad Pontificia Comillas.

LORAUX, Nicole (1988). Maneiras trágicas de matar uma mulher: Imaginário da Grécia Antiga. Rio de Janeiro: Jorge Zahar Editor.

LÖWY, Michael (2005). Walter Benjamin: Aviso de Incendio. Buenos Aires: FCE.

LUKÁCS, G (1963). Significación actual del realismo crítico. México: Ed. Era. (2003). A Teoria do Romance. São Paulo: Duas Cidades/ Ed. 34.

MACHADO, Irene A (1995). O romance e a voz: a prosaica dialógica de M. Bakhtin. Rio de Janeiro: Imago.

MARTIN GAITE, Carmen (1992). Desde la ventana. Madrid: Espasa Calpe.

MAZEL, Jacques (1988). As metamorfoses de Eros: o amor na Grécia Antiga. São Paulo: Martins Fontes.

MENÉNDEZ Y PELAYO (1943). Orígenes de la novela. Madrid, Santander Aldus.

MENESES, Adélia Prado de (1995). Do poder da palavra: Ensaios de Literatura e Psicanálise. São Paulo, Duas Cidades.

MONLEÓN, José B (1995). Del franquismo a la postmodernidad. Madrid: Akal.

MONTEJO GURRUCHAGA, Lucía et BARANDA LETURIO, Nieves (2002). Las Mujeres escritoras en la historia de la Literatura Española. Madrid: UNED Ediciones. 
MORET, Zulema (2000). "Y las niñas que crecen ¿a dónde van a parar? In Feminismos, Cuerpos, escrituras. Santa Cruz de Tenerife: La Página Ediciones.

MURIEL TAPIA, María Cruz (1991). Antifeminismo y subestimación de la mujer en la literatura medieval. Cáceres: Ed. Guadiloba.

NAVAJAS, Gonzalo (1985). Mimesis y cultura en la ficción: una teoría de la novela. Madrid: Támesis.

NEUMANN, Erich (1993). Amor e Psique uma interpretação psicológica do conto de Apuleio: uma contribuição para o desenvolvimento da psique feminina.

São Paulo: Cultrix.

NICHOLS, Geraldine C. (1995). "Ni Una, ni "Grande", ni Liberada: la narrativa de mujer en la España demócrata". In VV.AA.. Del franquismo a la posmodernidad. Madrid: ed. Akal.

OBRA, Sebastián de la et RODRÍGUEZ DE AZA, Rosana (2000). "Boceto de una presencia: mujeres de Al Andaluz" in ZAVALA, Iris M. (ed.) Feminismos, cuerpos, escrituras. Madrid: La página ediciones, pp. 99-120.

OLIVEIRA, Nythamar Fernandes de (2002). "Hegel, Heidegger, Derrida:

Desconstruindo a Mitologia Branca". in Veritas 47/1: 81-97.

ORDÓÑEZ, Elizabeth J.(1995) "Escribir contra el archivo: nueva narrativa de mujer" in AA.VV. Del Franquismo a la Posmodernidad. Madrid: ediciones Akal.

OREJAS, Francisco G (2003). La metaficción en la novela española contemporánea. Madrid: Arcos.

ORTEGA Y GASSET, José (1961). "El peligro que es el otro y la sorpresa que es el yo" in Obras Completas Tomo VI. Madrid: Revista de Occidente. pp. 174 196.

ORLANDI, Eni Puccinelli (2002). As formas do silêncio: No movimento dos sentidos $-5^{\mathrm{a}}$ ed. Campinas: Editora da Unicamp.

Sentidos. Campinas: Pontes.

OTEYZA, Luiz de (1917). Las Mujeres de la Literatura. Madrid: Librería de la viuda de Pueyo.

PAMPA ARÁN, O. (1998). La estilística de la novela en M.M. Bajtin. Teoría y aplicación metodológica, Córdoba (Argentina), Narvaja Editor.

PAZ, Octavio (1995). La llama doble: amor y erotismo. Barcelona: Seix Barral.

PEREIRA, Maria Helena da Rocha (1967). Estudos de história da Cultura Clássica. 
- $2^{\mathrm{a}}$ ed.- Lisboa: Fundação Calouste Gulbenkian.

PESSOA, FERNANDO (1998). Poemas de Álvaro de Campos. Ed. Bilíngüe. Trad. e notas Adolfo Monteiro Navas. Madrid: Hiperión, vol II.

PHILLIPS, Adams (1998). “O Amor” in O flerte. São Paulo: Cia das Letras, pp. 75-8.

RAMA, Angel (1980). "La tecnificación Narrrativa” in Hispamérica. No. 30, pp. 27-82.

(1989). Transculturación Narrativa en América Latina. Montevideo: Fundación Angel Rama.

RAMA, Angel (1980). "La tecnificación Narrrativa" in Hispamérica. No. 30, pp. 27-82.

(1989). Transculturación Narrativa en América Latina. Montevideo: Fundación Angel Rama.

ROSA, João Guimarães (1988). Primeiras Histórias. Rio de Janeiro: Nova Fronteira.

ROUGEMONT, Denis de (1986). El amor y Occidente. 4a. ed. Barcelona: Kairós.

RUBIO, Fanny (ed.) (2005). El Quijote en clave de mujer/es. Madrid: ed. Complutense.

RUKSER, Udo (1977). Goethe en el Mundo Hispánico. Madrid: FCE.

SANT'ANNA, Afonso Romano de (1988). Paródia, Paráfrase \& Companhia. 3. ed., São Paulo, Ática.

SANTAELLA, Lúcia (1992). A assinatura das coisas. Peirce e a Literatura. Rio de Janeiro, Imago.

SANTOS, Roberto Corrêa dos(1991). "Discurso feminino, corpo, arte gestual, as margens Recentes" in Revista Tempo Brasileiro, vol. 104. Rio de Janeiro: Tempo Brasileiro.

SARLO, Beatriz (1993). Borges, un escritor en las orillas. Buenos Aires, Ariel.

SEGOLIN, Fernando (1978). Personagem e anti-personagem. São Paulo: Cortez e Moraes.

SILVA, Calane da (1993). "Asas da prosa no Pássaro da Poesia" in Maderazinco: Revista Literária Moçambicana. Maputo. 
SISSA, Giulia et DETIENNE, Marcel (1990). Os deuses gregos. Trad. Rosa Maria Boaventura. São Paulo: Cia das Letras.

TELES, Gilberto Mendonça (1979) A Retórica do Silêncio. São Paulo: Cultrix.

TODOROV, Tzvetan (1979). Poética da Prosa. Lisboa: Edições 70.

TOLEDO, Carmen. "Féminas, femeninas, feministas que escriben." In Leer, Junio 2000 pp. 28-31.

TORO, Alfonso de et INGENSCHAY, Dieter (eds.-1995). La novela española actual: Autores y tendencias. Kassel : Reichenberger.

VAN GENNEP, Arnold (1992). Os ritos de passagem. Petrópolis: Vozes, $11^{a}$.ed.

VERNANT, Jean-Pierre (1988). A morte nos olhos: Figuração do Outro Na Grécia antiga. Trad. Clóvis Marques. Rio de Janeiro: Jorge Zahar Editor.

. (1990) Mito e pensamento entre os gregos: estudos de psicologia histórica. Trad. Haigamuch Sarian. Rio de Janeiro: Paz e Terra.

(1992). Mito e sociedade na Grécia arcaica. Trad. Myriam Campello. Rio de Janeiro: Ed. da UnB/ José Olympio.

VERNANT, Jean-Pierre et DETIENNE, Marcel (1988). Las artimañas de la inteligencia: La metis en la Grecia antigua. Trad. Antonio Piñero. Madrid: Taurus.

VV.AA. (1995) Del franquismo a la posmodernidad. Madrid: Akal.

WATANABE, Lygia Araujo (1996). Platão por mitos e hipóteses. São Paulo: Moderna.

ZAVALA, Iris (coord) (2000). Feminismo, cuerpo, escrituras. Santa Cruz de Tenerife: La Página Ediciones. 